Marquette University

e-Publications@Marquette

7-7-2016

\title{
Multifunctional Heterocyclic Scaffolds for Hybrid Lewis Acid/Lewis Base Catalysis of Carbon-Carbon Bond Formation
}

Dennis Wiedenhoeft

Marquette University, dennis.wiedenhoeft@marquette.edu

Adam R. Benoit

Marquette University

Yibiao Wu

Marquette University

Jacob D. Porter

Marquette University

Elisia Meyle

Marquette University

See next page for additional authors

Accepted version. Tetrahedron, Vol. 72, No. 27-28 (July 7, 2016): 3905-3916. DOI. (C) 2016 Elsevier Ltd. Used with permission 
Authors

Dennis Wiedenhoeft, Adam R. Benoit, Yibiao Wu, Jacob D. Porter, Elisia Meyle, Teresa H.W. Yeung, Raechel Huff, Sergey Lindeman, and Chris Dockendorff 


\title{
Multifunctional Heterocyclic Scaffolds for Hybrid Lewis Acid/Lewis Base Catalysis of Carbon-Carbon Bond Formation
}

\author{
Dennis Wiedenhoeft \\ Department of Chemistry, Marquette University, \\ Milwaukee, WI \\ Adam R. Benoit \\ Department of Chemistry, Marquette University, \\ Milwaukee, WI \\ Yibiao Wu \\ Department of Chemistry, Marquette University, \\ Milwaukee, WI \\ Jacob D. Porter \\ Department of Chemistry, Marquette University, \\ Milwaukee, WI \\ Elisia Meyle \\ Department of Chemistry, Marquette University, \\ Milwaukee, WI
}

Tetrahedron, Vol 72, No. 27-28 (July 7, 2016): pg. 3905-3916. DOI. This article is @ Elsevier and permission has been granted for this version to appear in e-Publications@Marquette. Elsevier does not grant permission for this article to be further copied/distributed or hosted elsewhere without the express permission from Elsevier. 
NOT THE PUBLISHED VERSION; this is the author's final, peer-reviewed manuscript. The published version may be accessed by following the link in the citation at the bottom of the page.

\author{
Teresa H.W. Yeung \\ Department of Chemistry, Marquette University, \\ Milwaukee, WI \\ Raechel Huff \\ Department of Chemistry, Marquette University, \\ Milwaukee, WI \\ Sergey V. Lindeman \\ Department of Chemistry, Marquette University, \\ Milwaukee, WI \\ Chris Dockendorff \\ Department of Chemistry, Marquette University, \\ Milwaukee, WI
}

\begin{abstract}
Several new classes of hybrid catalysts have been synthesized by tethering heterocyclic metal (Lewis acid) chelating scaffolds to several different amines capable of facilitating enamine catalysis. Oxazole, thiazole, and imidazole-based chiral precatalysts were prepared in several steps from amino acid starting materials, and these were combined with a variety of metal Lewis acids for potential use as catalysts for various carbon-carbon bond formations. Air- and moisture-tolerant catalysts for enantioselective direct aldol reactions with activated benzaldehyde acceptors were identified, with optimal results obtained with proline-derived oxazole-carboxamide precatalysts combined with $\mathrm{Zn}(\mathrm{OTf})_{2}$ or lanthanide (III) salts. Control studies support the hypothesis that these act as unimolecular hybrid catalysts for the aldol reaction of propionaldehyde and 4-nitrobenzaldehyde.
\end{abstract}

\title{
Graphical abstract
}

\section{Hybrid Lewis acid/Lewis base catalysts}

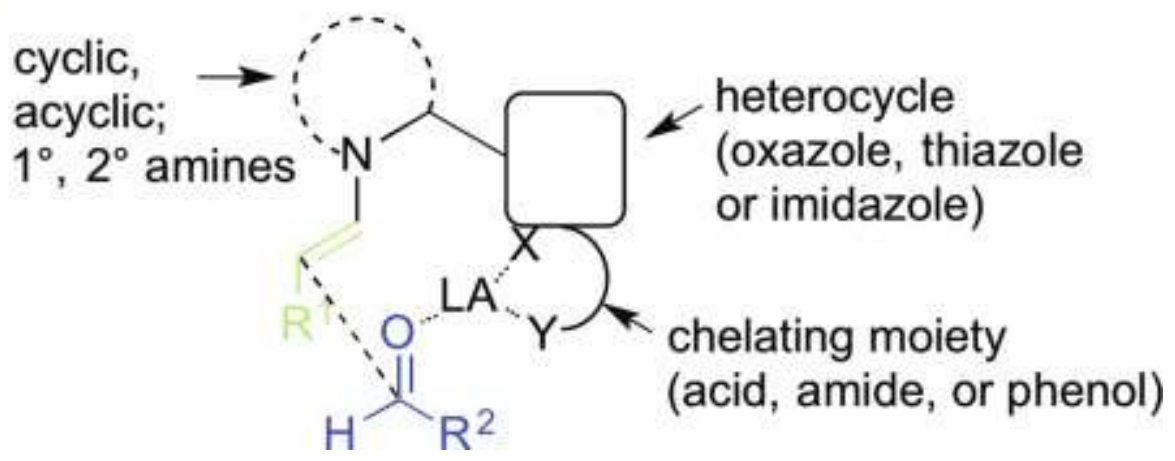

Tetrahedron, Vol 72, No. 27-28 (July 7, 2016): pg. 3905-3916. DOI. This article is C Elsevier and permission has been granted for this version to appear in e-Publications@Marquette. Elsevier does not grant permission for this article to be further copied/distributed or hosted elsewhere without the express permission from Elsevier. 
NOT THE PUBLISHED VERSION; this is the author's final, peer-reviewed manuscript. The published version may be accessed by following the link in the citation at the bottom of the page.

Keywords: Hybrid catalyst, Organocatalyst, Lewis acid, Heterocycle, Aldol reaction

\section{Introduction}

The use of multifunctional catalysts capable of activating multiple reaction partners remains an underutilized strategy in organic synthesis. ${ }^{1}$ One such approach involves the use of hybrid catalysts with Lewis acids and Lewis bases in close proximity on the same molecule, $1 ; \underline{2} ; \underline{3}$ which differs from the more common strategy of using separate catalysts, which is termed cooperative, synergistic, or dual catalysis (Fig. 1, top). $\underline{4} \underline{5}$ Instructive examples of hybrid Lewis acid/Lewis base catalysts include type-II aldolases which utilize hydroxyketone substrates, $\underline{6}$ ferrocenylphosphine-gold(I) complexes with tethered amines reported by Ito and Hayashi for asymmetric aldol reactions with isocyanoacetate substrates, $\underline{\underline{ }}$ bifunctional phosphine oxide/aluminum(III) catalysts for aldehyde cyanosilylation, ${ }^{8}$ and cinchona alkaloid-salicylate ligated In(III) for chiral $\beta$-lactam synthesis. ${ }^{9}$

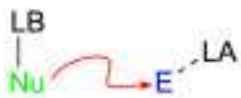

Discreet Lewis acid (LA) and Lewis base (LB) catalysts for activation of electrophile $(\mathrm{E})$ and nucleophile $(\mathrm{Nu})$ :

Cooperative, synergistic, or dual catalysis

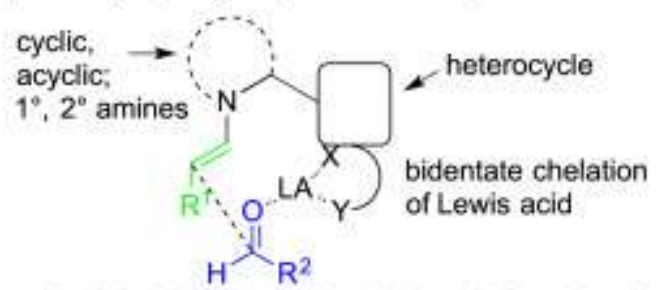

This work: hybrid Lewis acid/Lewis base bifunctional catalysts and application to aldol reactions

Fig. 1. Dual catalysis versus hybrid catalysis.

Small molecule organocatalysis has emerged as an extremely powerful tool in synthetic chemistry, 10 but practical limitations include low turnover frequencies relative to many industrial transition metal catalysts, as well as limited substrate scope in some cases. Additionally, the ability to access alternative diastereoisomeric products by catalyst modification is presently a significant challenge 
that is not unique to organocatalysis, despite recent successes in the area of synergistic organo/transition metal catalysis. $\underline{11}$

We believe that hybrid Lewis acid/Lewis base catalysts capable of stabilizing well-defined transition states and assembled using modular, easily modifiable organic building blocks may show improved performance and/or complementary scope relative to current organocatalysts. A reaction of particular interest to us for the preparation of antibiotic and anticancer natural product analogs is the direct aldol reaction, which forms carbon-carbon bonds between 'donor' and 'acceptor' aldehydes and ketones without the requirement of substrate preactivation. Numerous catalytic asymmetric direct aldol reactions have been reported, $\underline{12}$; $\underline{13}$ but many of these suffer from sluggish reactions with less activated acceptors, and few catalysts are presently capable of promoting enantioselective syn-selective reactions without a-heteroatom containing donors. $14 ; \underline{15} ; \underline{16} ; \underline{17}$ To address these challenges, but more generally to investigate underexplored strategies for the catalysis of carbon-carbon bond formations, we have initiated detailed investigations into hybrid Lewis acid/Lewis base catalysts for use in several transformations.

The amino acid proline, $\underline{18}$ as well as numerous proline derivatives, are well established for the production of anti-aldol products. Replacement of the carboxylic acid moiety of proline with suitably positioned chelated Lewis acids offers the opportunity to access alternative product stereochemistries, and could additionally provide improved reactivity over monofunctional catalysts. The use of metal Lewis acids with various amino acid derivatives as bifunctional aldol reaction catalysts has been reported over the years by the groups of Watanabe, $\underline{19}$ Darbre, $\underline{20}$ Mlynarski, $\underline{21}$ Aoki, $\underline{22}$ Wang, $\underline{23} ; \underline{24}$; 25 and Reiser. $\underline{26}$ However, to our knowledge, no data has been reported on the use of such hybrid aldol reaction catalysts with aldehyde donors that would be particularly useful for the synthesis of chiral polyproprionate fragments and building blocks for the synthesis of modified natural products. $\stackrel{27}{ }$ This manuscript describes the preparation of several novel heterocyclic precatalysts, as well as their application in direct aldol reactions.

Tetrahedron, Vol 72, No. 27-28 (July 7, 2016): pg. 3905-3916. DOI. This article is @ Elsevier and permission has been granted for this version to appear in e-Publications@Marquette. Elsevier does not grant permission for this article to be further copied/distributed or hosted elsewhere without the express permission from Elsevier. 
NOT THE PUBLISHED VERSION; this is the author's final, peer-reviewed manuscript. The published version may be accessed by following the link in the citation at the bottom of the page.

\section{Results and discussion}

One of the main challenges associated with creating a bifunctional hybrid catalyst is the need to keep the Lewis acid and Lewis base moieties from reacting with each other, while at the same time positioning them close enough in space to facilitate the key bond formation between nucleophile and electrophile. To meet these requirements, we have focused on the preparation of five-membered heterocycles that are capable of complexing Lewis acidic metals, and we have prepared a focused library of bifunctional precatalysts possessing these heterocycles tethered to several amines capable of enamine formation (Fig. 1, bottom).

\subsection{Azole-carboxylate precatalysts}

Our first series of bifunctional precatalysts are derived from chiral aamino acids and possess oxazole-carboxylate chelating functionality. The synthesis of our first precatalyst in this category is outlined in Scheme 1.
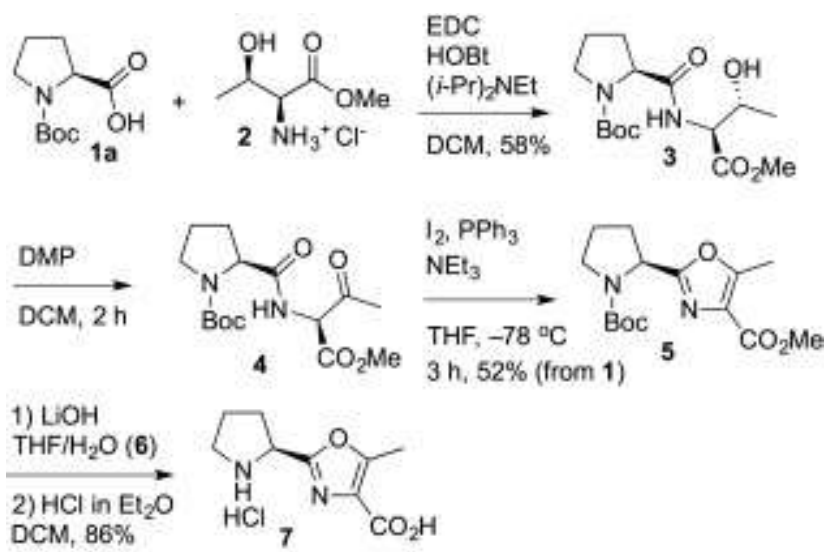

Scheme 1. Oxazole-carboxylates via oxidation-condensation sequence.

The synthesis started with a peptide coupling between $N$-Boc-Iproline and I-threonine methyl ester hydrochloride, which afforded the known dipeptide $\mathbf{3}$ in moderate yield. The dipeptide was oxidized to ketone 4 with Dess-Martin Periodinane (DMP), then subjected to a cyclization reaction with conditions developed by Wipf (triphenylphosphine, iodine, and triethylamine) 28 to generate the protected oxazole 5 in $52 \%$ yield. Lithium hydroxide hydrolysis of the 
methyl ester followed by acid-mediated removal of the Boc group afforded amino acid oxazole $\mathbf{7}$ as the $\mathrm{HCl}$ salt in good yield.

The limited solubility of putative amino acid precatalysts such as 7 in low polarity solvents inspired us to prepare variants with lipophilic solubility handles. For example, the use of 4-hydroxyproline as a starting material permits the convenient incorporation of lipophilic groups that would be expected to have a negligible impact on catalysis. The benzyl ether of $N$-Boc-I-proline (1b) was coupled with Iserine methyl ester to yield dipeptide $\mathbf{9 b}$ in excellent yield. Cyclization of $\mathbf{9 b}$ to generate an oxazoline with Deoxo-Fluor ${ }^{\mathrm{TM}}$ was followed by insitu bromination/elimination to form oxazole 10b, according to a protocol reported by Wipf and Williams, $\underline{29}$ which we modified slightly to incorporate an aqueous wash between steps. The methyl ester 10b was hydrolyzed to yield acid $\mathbf{1 1 \mathbf { b }}$, which could be coupled with additional building blocks (vide infra), or the Boc group could be removed with $\mathrm{HCl}$ to give amino acid 11b. An identical sequence was also used to prepare an intermediate without a solubility handle (11a). Valine-based precatalysts were also prepared in a similar manner, via Boc-protected compound 14 (Scheme 3).

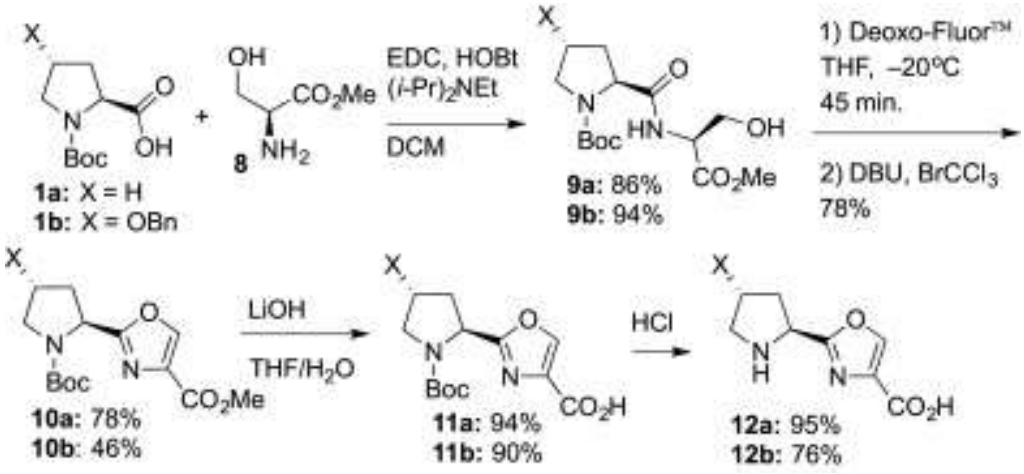

Scheme 2. Pyrrolidine-oxazole-carboxylates via cyclization/oxidation sequence.

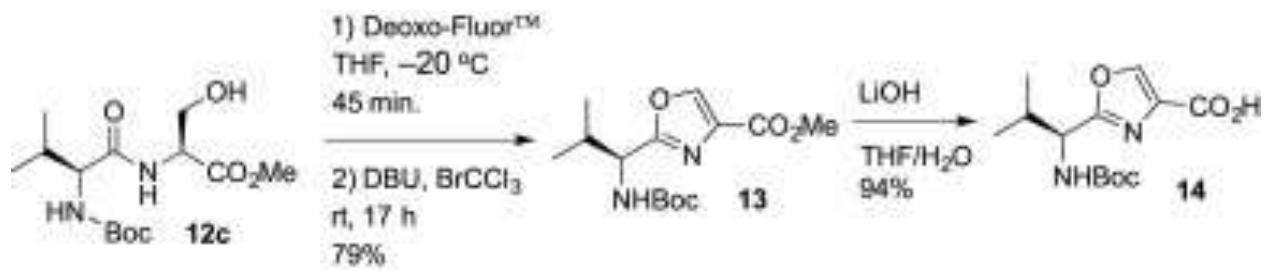

Scheme 3. Valine-based oxazole-carboxylates via cyclization/oxidation sequence.

Tetrahedron, Vol 72, No. 27-28 (July 7, 2016): pg. 3905-3916. DOI. This article is @ Elsevier and permission has been granted for this version to appear in e-Publications@Marquette. Elsevier does not grant permission for this article to be further copied/distributed or hosted elsewhere without the express permission from Elsevier. 
Analogous thiazole-based precatalysts were also synthesized via intermediate thioamides (Scheme 4). Treatment of keto-amide 4 with Lawesson's reagent $\underline{30}$ in refluxing THF generated thiazole $\mathbf{1 5}$ in moderate yield, which was subjected to the standard hydrolysis/deprotection conditions to yield acid $\mathbf{1 6}$ and amino acid $\mathbf{1 7}$.

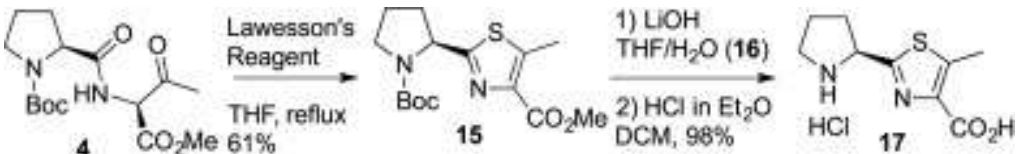

Scheme 4. Thiazole-carboxylates via thioamide formation.

\subsection{Azole-carboxamide precatalysts}

In order to generate several alternative functionalities capable of coordinating to Lewis acids and holding them in favorable orientations for bifunctional catalysis, we have coupled our $\mathrm{N}$ protected amino acids with a variety of building blocks. A small library of amides was prepared using standard peptide coupling reagents, and select examples generated from oxazoles 6, 11a, and 14, and thiazole 16, are given in Table 1. Representative syntheses are given in Schemes 6 and 7. Anilide compounds were the focus of these efforts, since they provide the opportunity to easily modulate the electronics of the coordinating amide. Additionally, amino alcohols were coupled using analogous conditions, and the resulting amido alcohols were used to prepare oxazoline moieties. The resulting precatalysts are the subject of a sister manuscript. $\underline{31}$

Table 1. Azole-carboxamide precatalysts

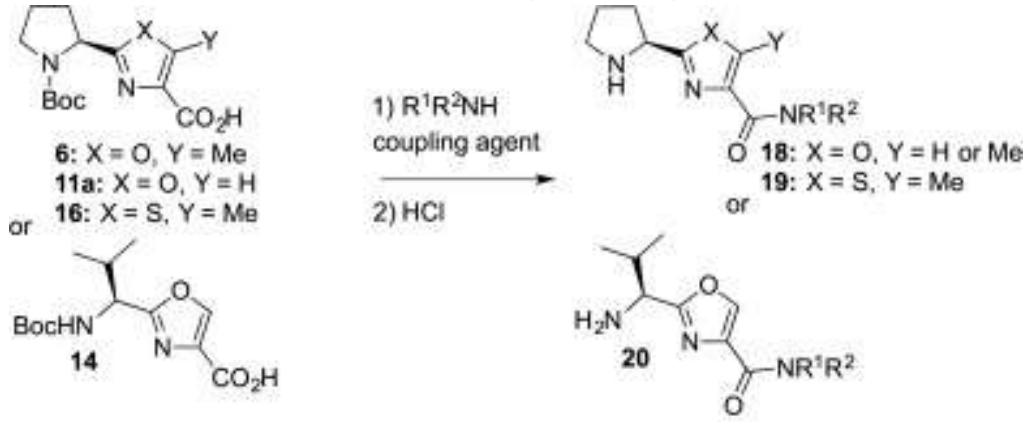

Tetrahedron, Vol 72, No. 27-28 (July 7, 2016): pg. 3905-3916. DOI. This article is (C) Elsevier and permission has been granted for this version to appear in e-Publications@Marquette. Elsevier does not grant permission for this article to be further copied/distributed or hosted elsewhere without the express permission from Elsevier. 
NOT THE PUBLISHED VERSION; this is the author's final, peer-reviewed manuscript. The published version may be accessed by following the link in the citation at the bottom of the page.

\section{Starting material}

6

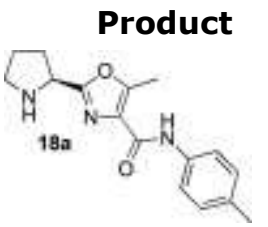

11a

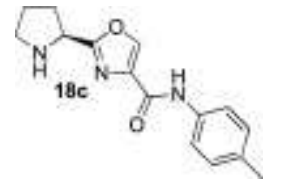

11a

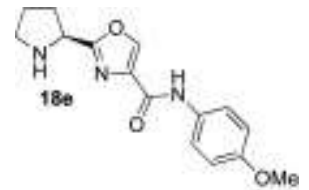

$11 a$

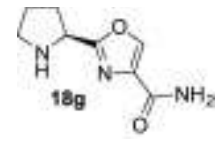

16

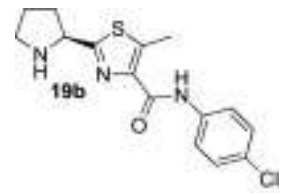

14

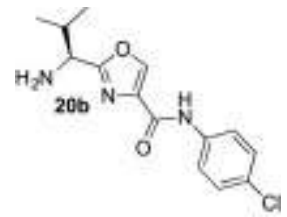

14

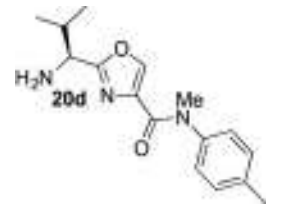

Starting material

6

Product

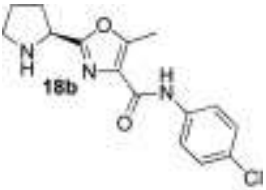

11a

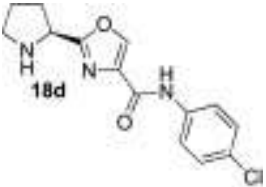

11a

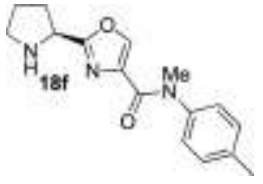

16

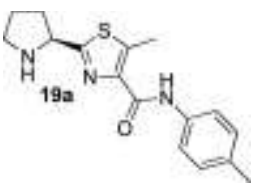

14

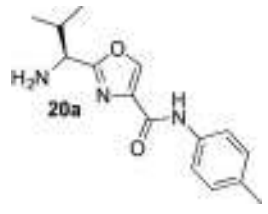

14

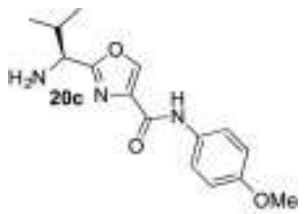

14

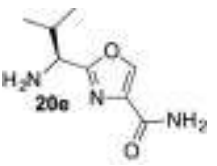

aReactions were performed with either EDC, PyBOP, or $i$-BuOCOCl as coupling agent. See Experimental section for representative examples.

\subsection{Imidazole-phenolate precatalysts}

In addition to carboxylic acids and carboxamides as chelating groups, we have also prepared a novel class of imidazole-phenolate precatalysts, with a representative example given in Scheme 5. Benzylation of o-hydroxyacetophenone $\mathbf{2 1}$ with sodium hydride and benzyl bromide proceeded smoothly to afford benzyl ether 22, followed by a-bromination with NBS under solvent-free conditions. $\underline{32}$ The resulting bromoketone $\mathbf{2 3}$ was treated with sodium azide in DMF 
to afford azide 24. A protocol was developed that enabled the azide reduction and isolation of the sensitive amino ketone $\mathbf{2 5}$ cleanly as the $\mathrm{HCl}$ salt. After several low yielding and messy Staudinger reduction reactions, the azide was cleanly hydrogenated using $\mathrm{Pd} / \mathrm{C}$ poisoned with diphenylsulfide, according to the report by Sajiki. $\frac{33}{3}$ The reaction was performed in acidic methanol to ensure that the resulting amine would immediately be protonated to circumvent intermolecular reactions with the acetophenone. The aminoketone $\mathbf{2 5}$ was then coupled with $\mathrm{N}$-Boc-I-phenylalanine to obtain amide $\mathbf{2 6}$. Heating with ammonium acetate facilitated a cyclodehydration reaction to yield the desired imidazole 27, which was globally deprotected with hydrogen and $\mathrm{Pd} / \mathrm{C}$, followed by $\mathrm{HCl}$, to provide the primary amine precatalyst 28a. The $N$-methyl phenylalanine-derived precatalyst $\mathbf{2 9}$ and the proline-derived precatalyst $\mathbf{3 0}$ were synthesized in a similar manner (see Supplementary data for details).

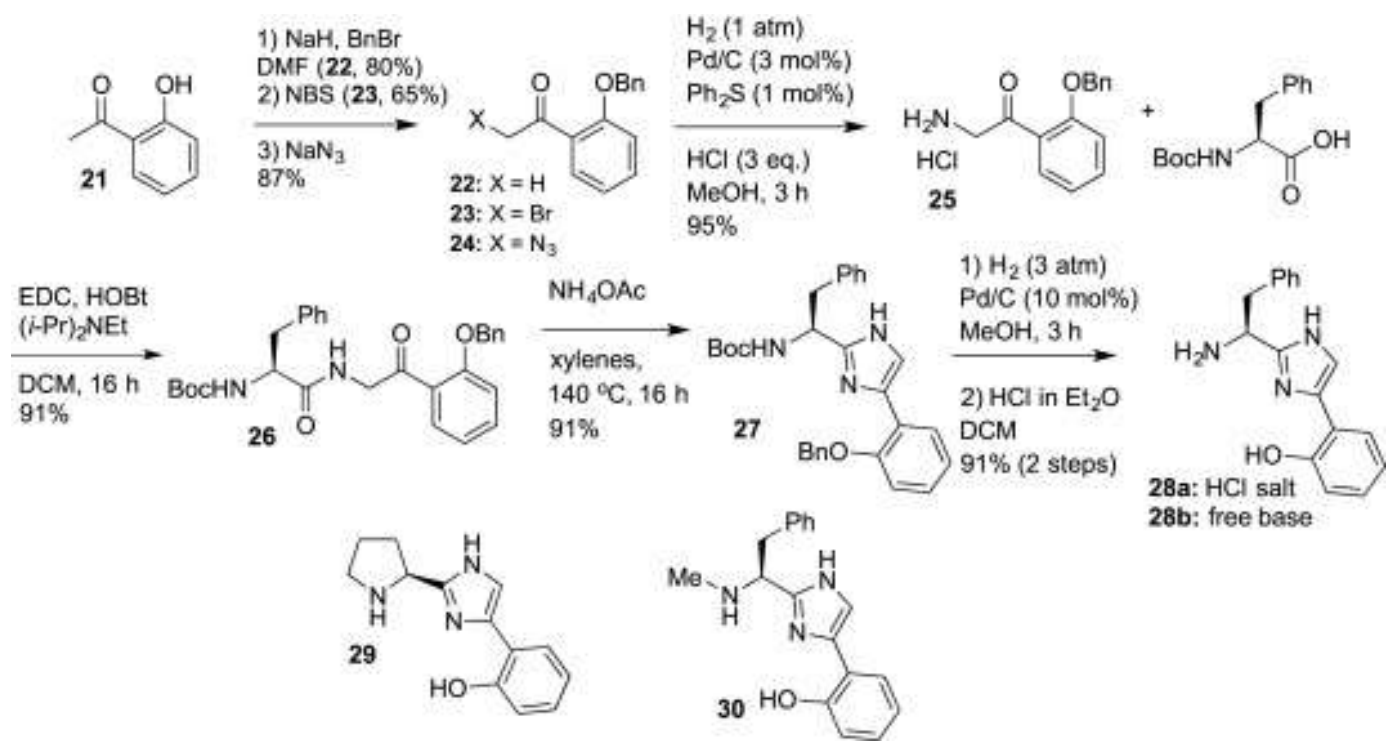

Scheme 5. Imidazole-phenolate precatalysts.

\subsection{Screening results}

Our interest in the preparation of modified natural products inspired us to explore the catalytic direct aldol reaction, using aldehyde donors as an initial testing ground for our first generation hybrid catalysts. After an initial lack of observed reactivity with lessactivated acceptors such as benzaldehyde, we elected to use the direct aldol reaction between propionaldehyde and 4-nitrobenzaldehyde as a

Tetrahedron, Vol 72, No. 27-28 (July 7, 2016): pg. 3905-3916. DOI. This article is @ Elsevier and permission has been granted for this version to appear in e-Publications@Marquette. Elsevier does not grant permission for this article to be further copied/distributed or hosted elsewhere without the express permission from Elsevier. 
model reaction. Our initial screens involved the combination of each of our precatalysts with at least 13 different metal salts, many of which have some precedent for acting as oxophilic, water-tolerant Lewis acids. $\frac{34}{~ F o r ~ p r o d u c t i v e ~ e n a m i n e ~ c a t a l y s i s ~ t o ~ o c c u r, ~ w a t e r ~ m u s t ~ b e ~}$ generated during enamine formation, but is also required to hydrolyze the imine or iminium ion intermediates generated upon carbon-carbon bond formation. Therefore, we took no special precautions to use dry glassware or to exclude air or moisture from reactions, though a commercial source of dry THF was used in the initial reaction screen (Table 2). The detailed screening protocol is provided in the Supplementary data, but in short the precatalysts and metal salts were simply added to reaction vials prior to the addition of substrate solutions, and the reactions were stirred for $24 \mathrm{~h}$ prior to a reductive quench with sodium borohydride solution to generate more stable 1,3diol products. Unless otherwise noted, all precatalysts were used as free bases or zwitterions. Yields and selectivities were determined by chiral HPLC.

Table 2. Representative screening results for direct aldol reaction of propionaldehyde and 4-nitrobenzaldehyde with acid and phenol precatalysts ${ }^{\text {a }}$

31a
0.2 mmol
Entry

aEnantiomeric excess (ee) and yields determined by chiral HPLC with 1,2dichlorobenzene as internal standard. Reactions were run for $24 \mathrm{~h}$ with $0.10 \mathrm{mmol}$ nitrobenzaldehyde (0.1 M final concentration), $0.20 \mathrm{mmol}$ propionaldehyde, and

Tetrahedron, Vol 72, No. 27-28 (July 7, 2016): pg. 3905-3916. DOI. This article is (C) Elsevier and permission has been granted for this version to appear in e-Publications@Marquette. Elsevier does not grant permission for this article to be further copied/distributed or hosted elsewhere without the express permission from Elsevier. 
$10 \mathrm{~mol} \%$ precatalyst and metal salt, unless otherwise noted. NR=no reaction $(<1 \%$ yield). $\mathrm{ND}=$ not determined.

Results with carboxylic acid and phenol-containing precatalysts are given in Table 2 . Some of our early amino acid precatalysts, such as $\mathbf{7}$ (entry 1), and $\mathbf{1 2 a}$ and $\mathbf{1 7}$ (not in table), proved to be quite insoluble in organic solvents, even in the presence of metal salts with added base. Therefore, we were not surprised to see a lack of reaction in such cases (e.g., entry 1). A solubility handle was added to these amino acid precatalysts by using hydroxyproline as a starting material; for example, benzyl ether 12b (Scheme 2) was synthesized and subjected to the model reaction. Moderate levels of reactivity and anti enantioselectivity were observed when combined with a number of Lewis acids (entries 3-6). The imidazole-phenol 28b, containing a primary amine as the organocatalytic moiety, gave very good syn selectivity when combined with $\mathrm{InCl}_{3}$, but low enantioselectivity and only moderate yield (entry 9). The secondary amine analogs $\mathbf{2 9}$ and 30 preferably formed the anti products with improved yields and in some cases moderately good enantioselectivity (with Zn(OTf) 2, entry 12). Unfortunately there is a potential background reaction with the imidazole-phenol class of catalysts, as precatalysts such as $\mathbf{2 8} \mathbf{b}$ are able to catalyze somewhat the syn-selective addition of propionaldehyde to 4-nitrobenzaldehyde without the use of metal salts (entry 7). Therefore, this compound class was deprioritized for this reaction.

The most promising results were obtained with the carboxamide-containing precatalysts (Table 3 ). The combination of these precatalysts with lanthanide Lewis acids frequently generated catalysts with improved reactivities and stereoselectivities, such as with the use of 18a and $\mathrm{Eu}(\mathrm{OTf})_{3}$ (entry 2: 61\% yield, 79\% anti selective, $61 \%$ ee). There were few clear-cut structure-activity relationships with these catalysts; there were examples of primary amides (e.g., 18g, entries 13-17), secondary amides, and tertiary amides (e.g., 18f, entries 11-12) that provided catalysts with good reactivities and enantioselectivities. However, we observed no thiazole-based catalysts with both good reactivity and enantioselectivity (entries 18-21). There were also not obvious electronic effects at the arene of the carboxamide, though the more electron-rich carboxamide $\mathbf{1 8 e}$ gave a superior yield to the 4 -chloro-

Tetrahedron, Vol 72, No. 27-28 (July 7, 2016): pg. 3905-3916. DOI. This article is @ Elsevier and permission has been granted for this version to appear in e-Publications@Marquette. Elsevier does not grant permission for this article to be further copied/distributed or hosted elsewhere without the express permission from Elsevier. 
substituted 18d with $\mathrm{Zn}(\mathrm{OTf})_{2}$ (entries 7 vs 9). Of particular note was that $\mathrm{Zn}(\mathrm{OTf})_{2}$ frequently generated catalysts with high anti enantioselectivities.

Table 3. Representative screening results for direct aldol reaction of propionaldehyde and 4-nitrobenzaldehyde with carboxamide precatalysts ${ }^{a}$

\begin{tabular}{|c|c|c|c|c|c|c|c|}
\hline Entry & Precatalyst & Metal salt & \% syn & syn ee & $\%$ anti & anti ee & $\%$ Yield \\
\hline 1 & $18 a$ & $\mathrm{Sm}(\mathrm{OTf})_{3}$ & 20 & 16 & 80 & 80 & 37 \\
\hline 2 & $18 a$ & $\mathrm{Eu}(\mathrm{OTf})_{3}$ & 21 & 9 & 79 & 61 & 61 \\
\hline 3 & $18 b$ & $\mathrm{Zn}(\mathrm{OTf})_{2}$ & 35 & 13 & 65 & 11 & 19 \\
\hline 4 & $18 b$ & $\mathrm{InCl}_{3}$ & 25 & 9 & 75 & 35 & 23 \\
\hline 5 & $18 \mathrm{C}$ & $\mathrm{Zn}(\mathrm{OTf})_{2}$ & 15 & 42 & 85 & 88 & 40 \\
\hline 6 & $18 \mathrm{C}$ & $\mathrm{InCl}_{3}$ & 45 & 18 & 55 & 21 & 78 \\
\hline 7 & $18 d$ & $\mathrm{Zn}(\mathrm{OTf})_{2}$ & 21 & 24 & 79 & 92 & 27 \\
\hline 8 & 18d & $\mathrm{Sm}(\mathrm{OTf})_{3}$ & 36 & 28 & 64 & 65 & 55 \\
\hline 9 & $18 e$ & $\mathrm{Zn}(\mathrm{OTf})_{2}$ & 18 & 44 & 82 & 84 & 51 \\
\hline 10 & $18 e$ & $\mathrm{Sm}(\mathrm{OTf})_{3}$ & 33 & 19 & 67 & 64 & 74 \\
\hline 11 & $18 f$ & $\mathrm{Zn}(\mathrm{OTf})_{2}$ & 18 & 49 & 82 & 91 & 45 \\
\hline 12 & $18 f$ & $\mathrm{InCl}_{3}$ & 34 & 12 & 66 & 52 & 61 \\
\hline 13 & $18 g$ & $\mathrm{Mg}(\mathrm{OTf})_{2}$ & 18 & 15 & 82 & 77 & 41 \\
\hline 14 & $18 g$ & $\mathrm{Zn}(\mathrm{OTf})_{2}$ & 20 & 52 & 80 & 84 & 48 \\
\hline 15 & $18 g$ & $\mathrm{InCl}_{3}$ & 41 & 15 & 59 & 25 & 80 \\
\hline 16 & $18 g$ & $\mathrm{Eu}(\mathrm{OTf})_{3}$ & 32 & 21 & 68 & 54 & 72 \\
\hline 17 & $18 g$ & $\mathrm{Yb}(\mathrm{OTf})_{3}$ & 33 & 18 & 67 & 65 & 55 \\
\hline 18 & $19 a$ & $\mathrm{Eu}(\mathrm{OTf})_{3}$ & 39 & 2 & 61 & 26 & 77 \\
\hline 19 & $19 a$ & $\mathrm{Yb}(\mathrm{OTf})_{3}$ & 46 & 20 & 54 & 11 & 63 \\
\hline 20 & 19b & $\mathrm{InCl}_{3}$ & 42 & 8 & 58 & 27 & 38 \\
\hline 21 & 19b & $\mathrm{Zn}(\mathrm{OTf})_{2}$ & 35 & 14 & 65 & 29 & 33 \\
\hline 22 & $20 a$ & None & ND & ND & ND & ND & 3 \\
\hline 23 & $20 a$ & $\mathrm{Zn}(\mathrm{OTf})_{2}$ & 59 & 58 & 41 & 63 & 19 \\
\hline 24 & $20 a$ & $\mathrm{InCl}_{3}$ & 79 & 20 & 21 & 13 & 25 \\
\hline 25 & $20 a$ & $\mathrm{Eu}(\mathrm{OTf})_{3}$ & 38 & 1 & 62 & 7 & 49 \\
\hline 26 & $20 a$ & $\mathrm{Yb}(\mathrm{OTf})_{3}$ & 50 & 12 & 50 & 17 & 42 \\
\hline 27 & $20 b$ & $\mathrm{Zn}(\mathrm{OTf})_{2}$ & 59 & 47 & 41 & 33 & 16 \\
\hline 28 & $20 b$ & $\mathrm{Eu}(\mathrm{OTf})_{3}$ & 46 & 0 & 54 & 11 & 42 \\
\hline 29 & $20 c$ & $\mathrm{Zn}(\mathrm{OTf})_{2}$ & 65 & 33 & 35 & 41 & 20 \\
\hline 30 & $20 c$ & $\mathrm{InCl}_{3}$ & 72 & 49 & 28 & 2 & 25 \\
\hline 31 & 20d & $\mathrm{Zn}(\mathrm{OTf})_{2}$ & 66 & 27 & 34 & 52 & 16 \\
\hline 32 & 20d & $\mathrm{InCl}_{3}$ & 84 & 6 & 16 & 5 & 27 \\
\hline 33 & $20 e$ & $\mathrm{Zn}(\mathrm{OTf})_{2}$ & 59 & 39 & 41 & 32 & 28 \\
\hline 34 & $20 e$ & $\mathrm{InCl}_{3}$ & 82 & 12 & 18 & 5 & 31 \\
\hline
\end{tabular}

aEnantiomeric excess (ee) and yields determined by chiral HPLC with 1,2-

dichlorobenzene as internal standard. Reactions were run for $24 \mathrm{~h}$ with $0.10 \mathrm{mmol}$

Tetrahedron, Vol 72, No. 27-28 (July 7, 2016): pg. 3905-3916. DOI. This article is @ Elsevier and permission has been granted for this version to appear in e-Publications@Marquette. Elsevier does not grant permission for this article to be further copied/distributed or hosted elsewhere without the express permission from Elsevier. 
nitrobenzaldehyde ( $0.1 \mathrm{M}$ final concentration), $0.20 \mathrm{mmol}$ propionaldehyde, and $10 \mathrm{~mol} \%$ precatalyst and metal salt. ND=not determined.

To differentiate the catalysts further, select examples were tested in reactions with propionaldehyde and the less activated acceptor benzaldehyde. One of the few combinations giving any observable reaction was $\mathbf{1 8 c}-\mathrm{Zn}(\mathrm{OTf})_{2}$ (Table 7). We therefore studied this catalyst in further detail to optimize reaction conditions with the original model reaction. Results with 18c and a variety of metal salts are given in Table 4. Only trace reaction was observed with triflate salts of $\mathrm{Mg}(\mathrm{II}), \mathrm{Sc}(\mathrm{III})$, and $\mathrm{Cu}(\mathrm{II})$ (entries 1-3). Interestingly, only trace reaction was observed with $\mathrm{ZnBr}_{2}$ (entry 4), but moderate reactivity and good enantioselectivity was measured with $\mathrm{Zn}(\mathrm{OTf})_{2}$ (entry 5). Conversely, catalysis with $\mathrm{InCl}_{3}$ provided good yield, albeit with low enantioselectivities (entry 7), while In(OTf) 3 gave only trace reaction (entry 8$)$. Ga(OTf) 3 was the only metal complex providing any level of syn selectivity (61\%, entry 6$)$. Lanthanide (III) triflates (entries 9-12) promoted the reaction with moderate yields and moderate to good anti enantioselectivities. Based on the promising results with the initial benzaldehyde reactions and the good anti selectivity and enantioselectivity (entry 5), we continued to study $\mathbf{1 8 c}-\mathrm{Zn}(\mathrm{OTf})_{2}$ in further detail.

Table 4. Detailed metal salt screening with $\mathbf{1 8} \mathbf{c}^{\mathrm{a}}$

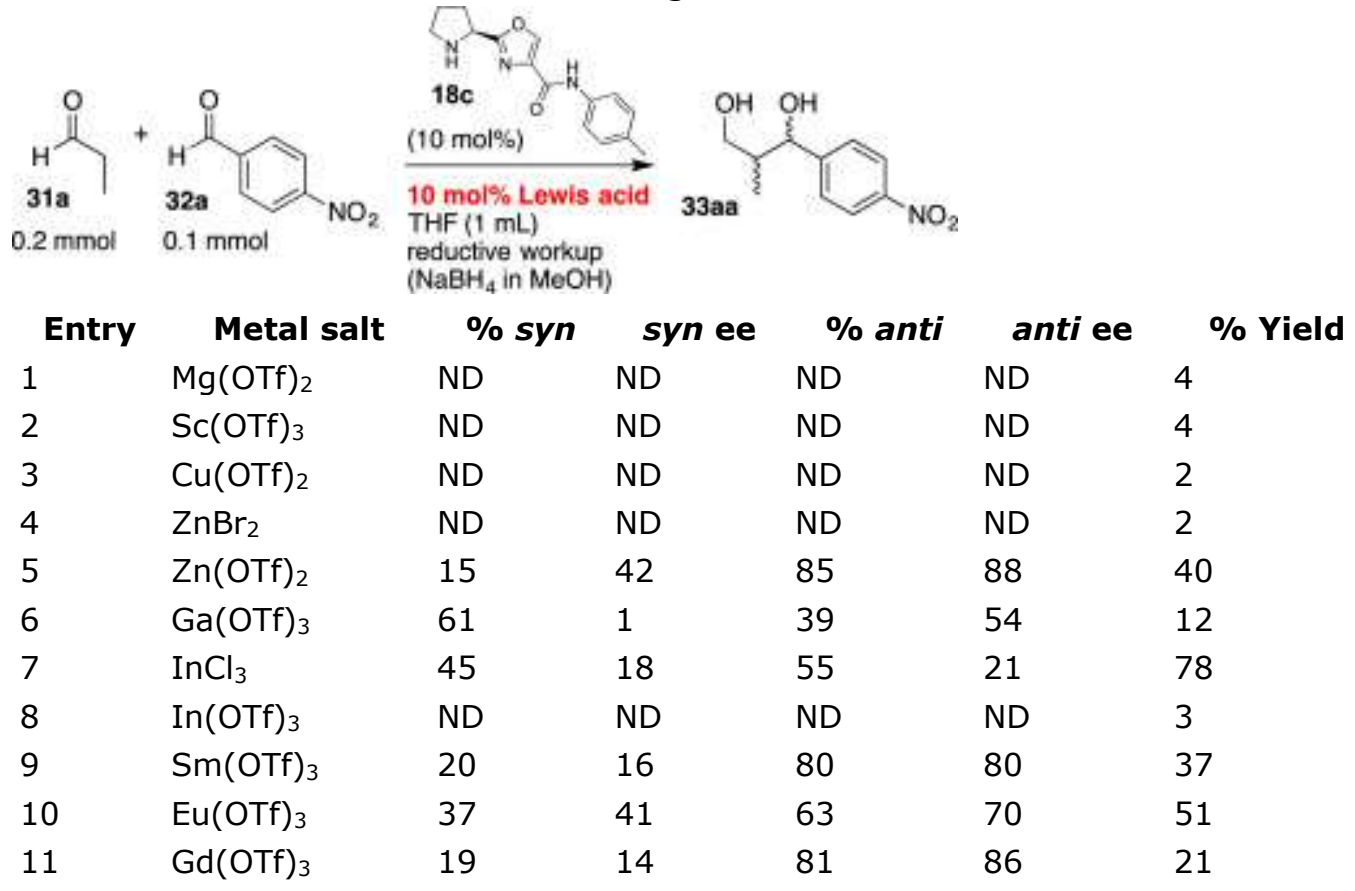


NOT THE PUBLISHED VERSION; this is the author's final, peer-reviewed manuscript. The published version may be accessed by following the link in the citation at the bottom of the page.

\begin{tabular}{lllllll} 
Entry & \multicolumn{1}{c}{ Metal salt } & \multicolumn{1}{c}{$\%$ syn } & syn ee & \% anti & anti ee & \% Yield \\
12 & $\mathrm{Yb}(\mathrm{OTf})_{3}$ & 31 & 3 & 69 & 68 & 38 \\
13 & $\mathrm{Bi}(\mathrm{OTf})_{3}$ & $\mathrm{ND}$ & $\mathrm{ND}$ & $\mathrm{ND}$ & $\mathrm{ND}$ & 1
\end{tabular}

aEnantiomeric excess (ee) and yields determined by chiral HPLC with 1,2-

dichlorobenzene as internal standard. Reactions were run for $24 \mathrm{~h}$ with $0.10 \mathrm{mmol}$ nitrobenzaldehyde $(0.1 \mathrm{M}$ final concentration), $0.20 \mathrm{mmol}$ propionaldehyde, and $10 \mathrm{~mol} \%$ precatalyst and metal salt. ND=not determined.

Table 5. Solvent screen with 18c- $\mathrm{Zn}(\mathrm{OTf})_{2^{\mathrm{a}}}$

S1a
Entry

aEnantiomeric excess (ee) and yields determined by chiral HPLC with 1,2dichlorobenzene as internal standard. Reactions were run for $24 \mathrm{~h}$ with $0.10 \mathrm{mmol}$ nitrobenzaldehyde $(0.1 \mathrm{M}$ final concentration), $0.20 \mathrm{mmol}$ propionaldehyde, and $10 \mathrm{~mol} \%$ precatalyst and metal salt, unless otherwise noted. ND=not determined.

Tetrahedron, Vol 72, No. 27-28 (July 7, 2016): pg. 3905-3916. DOI. This article is (c) Elsevier and permission has been granted for this version to appear in e-Publications@Marquette. Elsevier does not grant permission for this article to be further copied/distributed or hosted elsewhere without the express permission from Elsevier. 
Table 6. Control reactions for $\mathbf{1 8 c}-\mathrm{Zn}(\mathrm{OTf})_{2}$-catalyzed direct aldol reaction
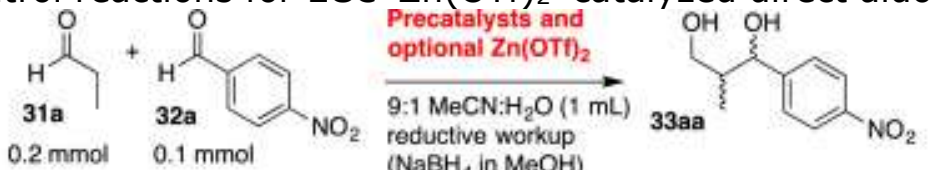

$\left(\mathrm{NaBH}_{4}\right.$ in $\left.\mathrm{MeOH}\right)$
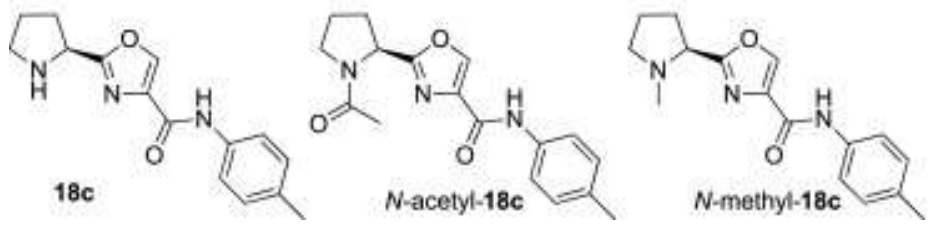

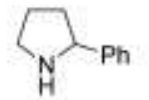

$( \pm) 2$-phenyl-pyrrolidine

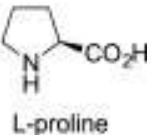

Entry

$$
\begin{gathered}
\text { Precatalyst(s) } \\
\text { (10 mol \%) }
\end{gathered}
$$

$1 \quad 18 c$

$2 \quad 18 \mathrm{C}$

3 None

$4 \quad 18 \mathrm{c}-\mathrm{HCl}$

$5 \quad \mathbf{1 8 c}-\mathrm{HCl}$

6 ( \pm )-2-Phenyl-pyrrolidine

7 ( \pm )-2-Phenyl-pyrrolidine

$8 \quad$ N-Acetyl-18c

$9 \quad N$-Acetyl-18c

10

$$
N \text {-Acetyl-18c+( } \pm \text { )-2- }
$$
phenyl-pyrrolidine

$11 \quad N$-Methyl-18c

$12 \quad N$-Methyl-18c

$$
\text { N-Methyl-18c+( }( \pm)-2-
$$
phenyl-pyrrolidine

14 I-Proline
None

$\begin{array}{lllll}48 & 7 & 52 & 41 & 6\end{array}$

$-\quad-\quad-\quad-\quad N R$

$\mathrm{Zn}(\mathrm{OTf})_{2}$

None

$\mathrm{Zn}(\mathrm{OTf})_{2}$

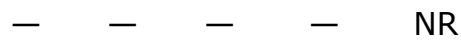

None

$\mathrm{Zn}(\mathrm{OTf})_{2}$

None

$\mathrm{Zn}(\mathrm{OTf})_{2}$

$\mathrm{Zn}(\mathrm{OTf})_{2}$

$\begin{array}{lllll}26 & 17 & 74 & 53 & 3\end{array}$

$61-39-30$

$61-39-11$

$-\quad-\quad-\quad-\quad N R$

ND ND ND ND 1

$\begin{array}{lllll}57 & 3 & 43 & 0 & 27\end{array}$

$\begin{array}{llllllllllllllll}\text { None } & - & - & - & - & - & \text { NR }\end{array}$

$\mathrm{Zn}(\mathrm{OTf})_{2}$

$-\quad-\quad-\quad-\quad$ NR

$\begin{array}{lllll}67 & 38 & 33 & 0 & 25\end{array}$

$\begin{array}{lllll}14 & 6 & 86 & 73 & 45\end{array}$

$\begin{array}{ccccc}\% & \text { syn } & \% & \text { anti } & \% \\ \text { syn } & \text { ee } & \text { anti } & \text { ee } & \text { Yield } \\ 20 & 32 & 80 & 76 & 54\end{array}$

aEnantiomeric excess (ee) and yields determined by chiral HPLC with $1,2-$

dichlorobenzene as internal standard. Reactions were run for $24 \mathrm{~h}$ at rt with $0.20 \mathrm{mmol}$ propionaldehyde $(0.1 \mathrm{M}$ final concentration), $0.10 \mathrm{mmol} 4$ -

nitrobenzaldehyde, and $10 \mathrm{~mol} \%$ precatalyst(s) and metal salt, unless otherwise noted. $\mathrm{ND}=$ not determined. $\mathrm{NR}=$ no reaction .

Table 7. Exploration of substrate scope

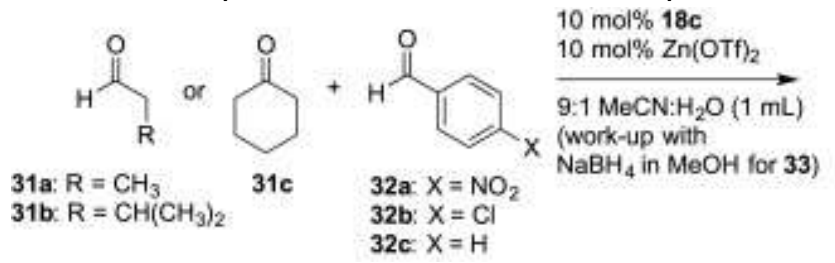

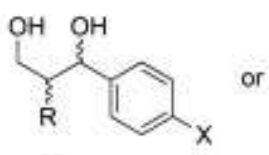

33

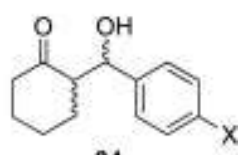

34

Entry Donor Acceptor Product \% syn \% syn ee \% anti \% anti ee \% Yield

$\begin{array}{lllllllll}1 & \text { 31a } & \text { 32a } & \text { 33aa } & 20 & 32 & 80 & 76 & 54 \\ 2 & \text { 31a } & \text { 32b } & \text { 33ab } & - & - & - & - & \text { NR } \\ 3 & \text { 31a } & \text { 32c } & \text { 33ac } & - & - & - & - & \text { NR } \\ 4 & \text { 31b } & \text { 32a } & \text { 33ba } & - & - & - & - & \text { NR }\end{array}$

Tetrahedron, Vol 72, No. 27-28 (July 7, 2016): pg. 3905-3916. DOI. This article is @ Elsevier and permission has been granted for this version to appear in e-Publications@Marquette. Elsevier does not grant permission for this article to be further copied/distributed or hosted elsewhere without the express permission from Elsevier. 
NOT THE PUBLISHED VERSION; this is the author's final, peer-reviewed manuscript. The published version may be accessed by following the link in the citation at the bottom of the page.

$\begin{array}{lllllllll}\text { Entry } & \text { Donor } & \text { Acceptor } & \text { Product } & \text { \% syn } \% \text { syn ee \% anti \% anti ee \% Yield } \\ 5 & \text { 31b } & \text { 32b } & \text { 33bb } & - & - & - & - & \text { NR } \\ 6 & \text { 31b } & \text { 32c } & \text { 33bc } & - & - & - & - & \text { NR } \\ 7 & \text { 31c } & \text { 32a } & \text { 34a } & 18 & 6 & 82 & 73 & 14 \text { a } \\ 8 & \text { 31c } & \text { 32b } & \text { 34b } & 46 & \text { ND } & 54 & \text { ND } & 12 \\ 9 & \text { 31c } & \text { 32c } & \text { 34c } & 33 & 44 & 67 & 51 & 15\end{array}$

Reactions were run with $0.4 \mathrm{mmol}$ acceptor and $0.8 \mathrm{mmol}$ donor with $10 \mathrm{~mol} \% \mathbf{1 8 c}$ and $10 \mathrm{~mol} \% \mathrm{Zn}(\mathrm{OTf})_{2}$ in $9: 1 \mathrm{MeCN}: \mathrm{H}_{2} \mathrm{O}$, for $24 \mathrm{~h}$ at $20{ }^{\circ} \mathrm{C}$ (with $32 \mathrm{a}$ ) or for $48 \mathrm{~h}$ at $70{ }^{\circ} \mathrm{C}$ (with $\mathbf{3 2} \mathbf{b}$ and $\mathbf{3 2 c}$ ). Enantiomeric excess (ee) and yield was determined by chiral HPLC with 1,2-dichlorobenzene as internal standard. Reductive work-ups were performed for reactions with aldehyde donors (31a, 31b). NR=no reaction.

aYield and diastereoselectivity determined by NMR.

Next, an investigation of solvent effects was carried out (Table 5). The model reaction was sluggish in benzene, but very good anti enantioselectivity ( $91 \%$ ee) was observed (entry 1 ). In prior aldol studies, we had observed improved reactivities with added water, but in this case increasing amounts of water with THF as the organic solvent did nothing to improve reaction yields or enantioselectivities (entries 4-9). In fact, sharply diminished anti enantioselectivities were observed with higher concentrations of water, potentially due to a reversible reaction. In contrast, the use of water as cosolvent with acetonitrile gave improved yields and anti enantioselectivity; we selected 9:1 MeCN: $\mathrm{H}_{2} \mathrm{O}$ (entry 14) as our solvent of choice for these reactions, despite the slightly higher enantioselectivities observed with the less polar solvents.

At this stage, it was important to determine if $\mathbf{1 8 c}-\mathrm{Zn}(\mathrm{OTf})_{2}$ is actually acting as a hybrid catalyst to promote the model aldol reaction. To address this question, we carried out a series of control reactions (Table 6$)$. A slight reaction (6\% yield) was observed with only $\mathbf{1 8 c}$ (entry 2 ) and no reaction was observed with only $\mathrm{Zn}(\mathrm{OTf})_{2}$ (entry 3). Little to no reaction was observed with the $\mathrm{HCl}$ salt of $\mathbf{1 8 c}$, either in the absence (entry 4 ) or presence (entry 5) of $\mathrm{Zn}(\mathrm{OTf})_{2}$. To explore the possibility of a dual catalyst mechanism, whereby $\mathbf{1 8 c}$ activates the donor via enamine formation for attack on the acceptor activated by a separate molecule of $\mathrm{Zn}(\mathrm{OTf})_{2}$, we examined the use of several precatalyst analogs that lacked either the metal chelating functionality or the amine moiety capable of activating the donor. First, the use of $( \pm)$-2-phenyl-pyrrolidine catalyzed the reaction to a

Tetrahedron, Vol 72, No. 27-28 (July 7, 2016): pg. 3905-3916. DOI. This article is @ Elsevier and permission has been granted for this version to appear in e-Publications@Marquette. Elsevier does not grant permission for this article to be further copied/distributed or hosted elsewhere without the express permission from Elsevier. 
significant extent ( $30 \%$ yield, entry 6$)$, indicating that simple amines can catalyze the model reaction, but this catalysis was attenuated by $\mathrm{Zn}(\mathrm{OTf})_{2}(11 \%$ yield, entry 7$)$, likely due to self-quenching. A precatalyst without an amine, $\mathrm{N}$-acetyl-18c, was unable to promote the reaction with or without $\mathrm{Zn}(\mathrm{OTf})_{2}$ (entries 8-9). The addition of $( \pm)$-2-phenyl-pyrrolidine to a mixture of $\mathrm{N}$-acetyl-18c, presumably still with the ability to complex $\mathrm{Zn}(\mathrm{OTf})_{2}$, and $\mathrm{Zn}(\mathrm{OTf})_{2}$ (all in $10 \mathrm{~mol} \%$ ), gave results very similar to that of $( \pm)$-2-phenyl-pyrrolidine alone (entry 10), in both yield and lack of enantioselectivity. This sequence of experiments was repeated with $N$-methyl-18c, which could possess the ability to act as a chiral base in the reaction (e.g., for enolate formation). However, no reaction was observed with $N$-methyl-18c (entries 11-12), and the addition of ( \pm )-2-phenyl-pyrrolidine to a mixture of $\mathrm{N}$-methyl-18c and $\mathrm{Zn}(\mathrm{OTf})_{2}$ again provided some reaction, though interestingly in this case some enantioselectivity was observed for formation of the syn isomer (entry 13). Clearly, the combination of $18 \mathrm{c}$ and $\mathrm{Zn}(\mathrm{OTf})_{2}$ is synergistic (entry 1 ), in particular with the elevated yields and significant enantioselectivity observed for the model reaction. The results of Table 5 are consistent with a unimolecular hybrid catalysis mechanism, whereby the Lewis acid and Lewis base are present in the same molecule (Fig. 1). To benchmark the performance of $\mathbf{1 8 c}-\mathrm{Zn}(\mathrm{OTf})_{2}$, and to confirm our HPLC peak assignments, we compared it to I-proline, tested under the same conditions (entry 14$) . \mathbf{1 8 c}-\mathrm{Zn}(\mathrm{OTf})_{2}$ performs very similarly to generate the anti product selectively with good, but not excellent, enantioselectivity (76\% ee under these conditions).

To determine the potential utility of our catalyst system, alternative aldol reactions were investigated (Table 7). Unfortunately, little practical substrate scope was observed with our optimal conditions. No reaction was observed between propionaldehyde and the less activated acceptors 4-chlorobenzaldehyde (entry 2) and benzaldehyde (entry 3 ), even at $70^{\circ} \mathrm{C}$. The use of isobutyraldehyde (31b) as donor also failed with all substrates (entries 4-6). Pleasingly, cyclohexanone gave reactions with all 3 acceptors, albeit in low yield. Moderately good anti enantioselectivity $(73 \%$ ee) was observed with 4-nitrobenzaldehyde as acceptor (entry 7).

Tetrahedron, Vol 72, No. 27-28 (July 7, 2016): pg. 3905-3916. DOI. This article is @ Elsevier and permission has been granted for this version to appear in e-Publications@Marquette. Elsevier does not grant permission for this article to be further copied/distributed or hosted elsewhere without the express permission from Elsevier. 
NOT THE PUBLISHED VERSION; this is the author's final, peer-reviewed manuscript. The published version may be accessed by following the link in the citation at the bottom of the page.

\subsection{Structural studies}

In order for hybrid catalysis to be feasible, it is critical that the Lewis acid and Lewis base moieties do not poison each other. Our catalysts have been designed with this objective in mind, but structural studies could potentially confirm this. To shed light on the specific interactions between the precatalysts and Lewis acids, we have initiated NMR, MS, and X-ray studies of a variety of systems. Preliminary NMR studies of $\mathrm{Zn}$ (II) containing catalysts demonstrate that complexation is indeed occurring, but the highly broad signals have thus far precluded characterization of discrete complexes. Mass spectrometry with electrospray ionization of 18c mixed with $\mathrm{Zn}(\mathrm{OTf})_{2}$ shows signals corresponding to two precatalyst molecules bound to zinc (see Supplementary data). Though it is possible that such 2:1 complexation observed in the mass spectrometer is not reflective of the major species present under reaction conditions, at this stage we cannot rule out the presence of higher order complexes with precatalysts such as $\mathbf{1 8 c}$ that may involve the reversible coordination of the amine nitrogen to zinc.

Thus far, we have obtained one crystal structure to indicate that our general catalyst design with a central five-membered heterocycle can facilitate the formation of metal complexes without self-quenching of the Lewis acid and Lewis base sites. A single crystal was obtained by mixing $12 \mathrm{a}$ and $\mathrm{NiI}_{2}$ in $1: 1 \mathrm{MeCN}$ : benzene (Fig. 2). Though this catalyst gave only trace reaction in the model reaction, it does illustrate that the amine and Lewis acid moieties can be situated close together without self-quenching. Two independent octahedral complexes, each with a 2:1 precatalyst to metal ratio, were present in the unit cell. It is clear that the pyrrolidine nitrogens in this structure are uncomplexed to metals, and thus would be available for activation of a donor reactant. Efforts are ongoing to obtain crystal structures of active aldol catalysts.

Tetrahedron, Vol 72, No. 27-28 (July 7, 2016): pg. 3905-3916. DOI. This article is @ Elsevier and permission has been granted for this version to appear in e-Publications@Marquette. Elsevier does not grant permission for this article to be further copied/distributed or hosted elsewhere without the express permission from Elsevier. 


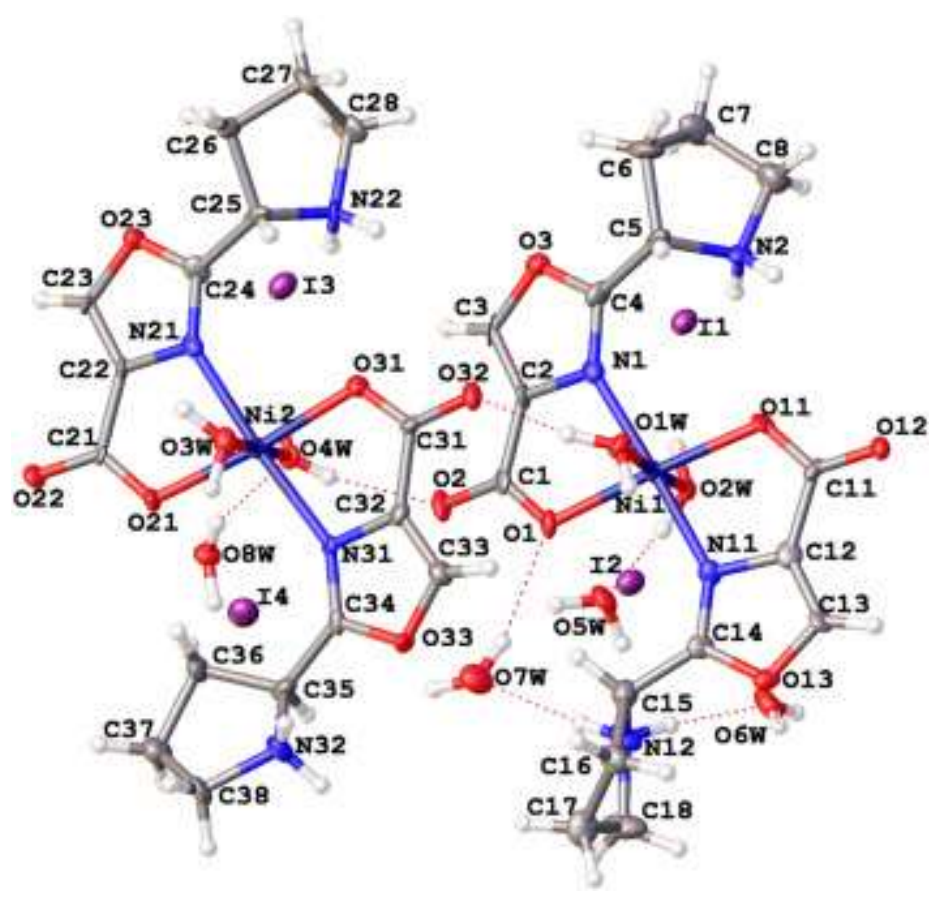

Fig. 2. X-ray crystal structure of $\mathbf{1 2 a}-\mathrm{NiI}_{2}\left(\mathrm{H}_{2} \mathrm{O}\right)_{2}$.

\section{Conclusion}

21 different amino acid-derived precatalysts have been synthesized, with each example containing an amine moiety capable of organocatalysis appended to a functionalized heterocycle designed to complex a Lewis acidic metal in an appropriate orientation for carboncarbon bond formation between 'donor' and 'acceptor' reactants. The functionalized heterocycles synthesized include examples of oxazoleand thiazole-carboxylates, imidazole-phenols, and oxazole- and thiazole-carboxamides. Many different putative hybrid catalysts were generated by mixing these catalysts with a variety of Lewis acids, and the catalysts were screened initially in the aldol reaction between propionaldehyde and 4-nitrobenzaldehyde. The carboxamide-based precatalysts gave the best combination of reactivity and enantioselectivity when used with certain metal salts, including zinc triflate and lanthanide (III) salts. The optimal catalysts were also selective for the anti stereoisomer, with enantiomeric excess of up to $91 \%$ observed. One of the optimal catalysts, 18c-Zn(OTf) 2 , was studied with a series of controls to support the hypothesis that it acts as a true hybrid catalyst to promote the desired aldol reaction. 
Despite these proof of concept results, our first-generation hybrid catalysts at this stage offer no obvious benefits over simpler organocatalysts for direct aldol reactions. Though the catalysts we have identified are tolerant of air and moisture and are highly robust (preliminary results show prolonged catalyst activity well beyond $24 \mathrm{~h}$ ), the substrate scope is very limited, and they suffer the same disadvantage of organocatalysts, namely sluggish reactions and/or high catalyst loading. The relatively low catalyst activity is also consistent with some previously reported hybrid catalysts for the direct aldol reaction. $\underline{24}$ We believe that alternative geometries for hybrid systems may lead to more reactive catalysts, and computational and synthetic efforts are underway to explore next-generation hybrid systems with well-defined ligand/metal geometries for the aldol and other carbon-carbon bond forming reactions.

\section{Experimental section}

\subsection{General information}

All reagents and solvents were purchased from commercial vendors and used as received. NMR spectra were recorded on Varian $300 \mathrm{MHz}$ or $400 \mathrm{MHz}$ spectrometers as indicated. Proton and carbon chemical shifts are reported in parts per million (ppm; $\delta$ ) relative to tetramethylsilane, $\mathrm{CDCl}_{3}$ solvent, or DMSO- $d_{6}\left({ }^{1} \mathrm{H} \delta 0,{ }^{13} \mathrm{C} \delta 77.16\right.$, or ${ }^{13} \mathrm{C} \delta 39.5$, respectively). NMR data are reported as follows: chemical shifts, multiplicity (obs=obscured, app=apparent, br=broad, $\mathrm{s}=$ singlet, $\mathrm{d}=$ doublet, $\mathrm{t}=$ triplet, $\mathrm{q}=$ quartet, $\mathrm{m}=$ multiplet, comp=complex overlapping signals); coupling constant(s) in $\mathrm{Hz}$; integration. Unless otherwise indicated, NMR data were collected at $25^{\circ} \mathrm{C}$. Flash chromatography was performed using Biotage SNAP cartridges filled with 40-60 $\mu \mathrm{m}$ silica gel, or C18 reverse phase columns (Biotage ${ }^{\circledR}$ SNAP Ultra C18 or Isco Redisep ${ }^{\circledR}$ Gold C18Aq) on Biotage Isolera systems, with photodiode array UV detectors. Analytical thin layer chromatography (TLC) was performed on Agela Technologies $0.25 \mathrm{~mm}$ glass plates with $0.25 \mathrm{~mm}$ silica gel.

Visualization was accomplished with UV light (254 nm) and aqueous potassium permanganate $\left(\mathrm{KMnO}_{4}\right)$ stain followed by heating, unless otherwise noted. Tandem liquid chromatography/mass spectrometry (LC-MS) was performed on a Shimadzu LCMS-2020 with autosampler,

Tetrahedron, Vol 72, No. 27-28 (July 7, 2016): pg. 3905-3916. DOI. This article is (C) Elsevier and permission has been granted for this version to appear in e-Publications@Marquette. Elsevier does not grant permission for this article to be further copied/distributed or hosted elsewhere without the express permission from Elsevier. 
photodiode array detector, and single-quadrupole MS with ESI and APCI dual ionization, using a Peak Scientific nitrogen generator. Unless otherwise noted, a standard LC-MS method was used to analyze reactions and reaction products: Phenomenex Gemini C18 column $(100 \times 4.6 \mathrm{~mm}, 3 \mu \mathrm{m}$ particle size, $110 \mathrm{~A}$ pore size); column temperature $40^{\circ} \mathrm{C} ; 5 \mu \mathrm{L}$ of sample in $\mathrm{MeOH}$ at a nominal concentration of $1 \mathrm{mg} / \mathrm{mL}$ was injected, and peaks were eluted with a gradient of $25-95 \% \mathrm{MeOH} / \mathrm{H}_{2} \mathrm{O}$ (both with $0.1 \%$ formic acid) over $5 \mathrm{~min}$, then $95 \% \mathrm{MeOH} / \mathrm{H}_{2} \mathrm{O}$ for 2 min. Purity was measured by UV absorbance at 210 or $254 \mathrm{~nm}$. High-resolution mass spectra were obtained at the University of Wisconsin-Milwaukee Mass Spectrometry Laboratory with a Shimadzu LCMS-IT-TOF with ESI and APCI ionization. Gas chromatography/mass spectrometry (GC-MS) was performed with Agilent Technologies 6850 GC with 5973 MS detector, and Agilent HP-5S or Phenomenex Zebron ZB-5MSi Guardian columns (30 m, $0.25 \mathrm{~mm}$ ID, $0.25 \mu \mathrm{m}$ film thickness). IR spectra were obtained as a thin film on $\mathrm{NaCl}$ or $\mathrm{KBr}$ plates using a Thermo Scientific Nicolet iS5 spectrometer. Optical rotations were measured with a Perkin Elmer 341 polarimeter at $\lambda=589 \mathrm{~nm}$, with a $10 \mathrm{~mL}$ cell with $10 \mathrm{~cm}$ path length. Specific rotations are reported as follows: $[a]_{D}{ }^{\circ} \mathrm{C}$ ( $c=\mathrm{g} / 100 \mathrm{~mL}$, solvent).

\subsection{Synthesis of precatalysts}

\subsection{1. tert-Butyl (S)-2-(((2S,3R)-3-hydroxy-1-methoxy-1- oxobutan-2-yI)carbamoyl)pyrrolidine-1-carboxylate (3)}

$\mathrm{N}$-Boc-I-Proline 1a $(1.02 \mathrm{~g}, 4.65 \mathrm{mmol})$, I-threonine methyl ester $\mathrm{HCl}$ salt $2(0.788 \mathrm{~g}, 4.65 \mathrm{mmol})$, $\mathrm{HOBt}(0.356 \mathrm{~g}, 2.32 \mathrm{mmol})$ and DIPEA (2.83 mL, $16.3 \mathrm{mmol})$ were dissolved in DCM $(40 \mathrm{~mL})$ at room temperature. After all solids had gone into solution, $\mathrm{EDC}-\mathrm{HCl}(1.07 \mathrm{~g}$, $5.58 \mathrm{mmol}$ ) was added and the mixture was stirred at room temperature for $3 \mathrm{~h}$. The reaction mixture was diluted with DCM $(100 \mathrm{~mL})$, washed with water $(50 \mathrm{~mL})$, saturated $\mathrm{NaHCO}_{3}(50 \mathrm{~mL})$, brine $(50 \mathrm{~mL})$, and dried over sodium sulfate. The combined organics were concentrated and purified by flash chromatography $\left(\mathrm{SiO}_{2}, 75 \%-\right.$ $85 \%$ EtOAc/hexanes) to give the title compound as a colorless oil (887 mg, 58\%). This compound has been previously reported and characterized (CAS\# 80897-23-0). ${ }^{1} \mathrm{H}$ NMR (300 MHz, DMSO-d $)$

Tetrahedron, Vol 72, No. 27-28 (July 7, 2016): pg. 3905-3916. DOI. This article is @ Elsevier and permission has been granted for this version to appear in e-Publications@Marquette. Elsevier does not grant permission for this article to be further copied/distributed or hosted elsewhere without the express permission from Elsevier. 
NOT THE PUBLISHED VERSION; this is the author's final, peer-reviewed manuscript. The published version may be accessed by following the link in the citation at the bottom of the page.

$\delta=0.86-0.1 .11(\mathrm{~m}, 3 \mathrm{H}), 1.23-1.46(\mathrm{~m}, 9 \mathrm{H}), 1.90-1.59(\mathrm{~m}, 3 \mathrm{H})$, 1.93-2.26 (m, 1H), 3.04-3.42 (m, 3H), 3.62 (t, J=2.1 Hz, 3 H), 3.80$4.18(\mathrm{~m}, 1 \mathrm{H}), 4.19-4.37(\mathrm{~m}, 2 \mathrm{H}), 4.82-5.02(\mathrm{~m}, 1 \mathrm{H}), 7.80(\mathrm{~d}$, $J=8.5 \mathrm{~Hz}, 1 \mathrm{H})$.

\subsubsection{Methyl (S)-2-(1-(tert-butoxycarbonyl)pyrrolidin-2-yl)-5- methyloxazole-4-carboxylate (5)}

Alcohol 3 (887 mg, $2.69 \mathrm{mmol}$ ) was dissolved in DCM (25 mL). Dess-Martin periodinane $(1.36 \mathrm{~g}, 3.22 \mathrm{mmol})$ was added. The reaction was stirred at room temperature for $2 \mathrm{~h}$, after which time the reaction was concentrated and pushed through a silica plug eluting with $7: 3$ EtOAc:hexanes. The eluent was concentrated to yield $1.21 \mathrm{~g}$ of the crude oil 4, which was carried onto the next step without further purification.

Triphenylphosphine $(1.63 \mathrm{~g}, 6.20 \mathrm{mmol})$ and iodine $(1.45 \mathrm{~g}$, $5.71 \mathrm{mmol}$ ) were sealed in a flask under $\mathrm{N}_{2}$ and dissolved with dry THF $(25 \mathrm{~mL})$, then cooled to $-78{ }^{\circ} \mathrm{C}$. Triethylamine $(1.50 \mathrm{~mL}, 5.71 \mathrm{mmol})$ was added via syringe, followed by the dropwise addition of crude 4 $(1.21 \mathrm{~g})$ in THF $(15 \mathrm{~mL})$ via syringe. After addition, the reaction was stirred at $-78{ }^{\circ} \mathrm{C}$ for $3 \mathrm{~h}$, then warmed to room temperature and diluted with water $(100 \mathrm{~mL})$ and extracted with DCM $(2 \times 75 \mathrm{~mL})$. The combined organics were washed with water $(75 \mathrm{~mL})$, sodium thiosulfate solution in water $(75 \mathrm{~mL})$, and brine $(75 \mathrm{~mL})$, then dried over sodium sulfate and concentrated. The crude oil was purified by chromatography ( $\mathrm{SiO}_{2}, 12 \%-100 \%$ EtOAc/hexanes) to give the title compound as a colorless oil (590 mg, 52\%). This compound has been previously reported and characterized (CAS\# 182360-15-2). ${ }^{1} \mathrm{H}$ NMR $\left(400 \mathrm{MHz}, \mathrm{CDCl}_{3}\right) \delta=1.27-1.49(\mathrm{~m}, 9 \mathrm{H}), 1.85-1.98(\mathrm{~m}, 1 \mathrm{H}), 1.99-$ $2.17(\mathrm{~m}, 2 \mathrm{H}), 2.2-2.38(\mathrm{~m}, 1 \mathrm{H}), 2.60(\mathrm{~s}, 3 \mathrm{H}), 3.36-3.67(\mathrm{~m}, 2 \mathrm{H})$, $3.8-3.97(\mathrm{~m}, 3 \mathrm{H}), 4.81-4.99(\mathrm{~m}, 1 \mathrm{H})$.

\subsection{3. (S)-2-(4-Carboxy-5-methyloxazol-2-yl)pyrrolidin-1-ium chloride (7)}

Oxazole 5 (593 mg, $1.90 \mathrm{mmol}$ ) was dissolved in THF (15 mL) and water $(15 \mathrm{~mL})$, followed by the addition of $\mathrm{LiOH}(80.0 \mathrm{mg}$, $1.90 \mathrm{mmol}$ ). The reaction was stirred at room temperature for $2 \mathrm{~h}$, after which time the $\mathrm{pH}$ was adjusted to 2 with concentrated aqueous

Tetrahedron, Vol 72, No. 27-28 (July 7, 2016): pg. 3905-3916. DOI. This article is C) Elsevier and permission has been granted for this version to appear in e-Publications@Marquette. Elsevier does not grant permission for this article to be further copied/distributed or hosted elsewhere without the express permission from Elsevier. 
$\mathrm{HCl}$, and the mixture was extracted with $\mathrm{DCM}(3 \times 50 \mathrm{~mL})$. The combined organics were washed with water $(50 \mathrm{~mL})$ and brine $(50 \mathrm{~mL})$, then dried over sodium sulfate and concentrated to yield a viscous oil. The oil was dissolved in DCM $(30 \mathrm{~mL})$, excess $4 \mathrm{~N} \mathrm{HCl}$ in dioxane was added, and the reaction was stirred for $16 \mathrm{~h}$, yielding a white precipitate. The precipitate was collected by filtration, washed with DCM, and dried under high vacuum to give the title compound as a white solid (379 mg, 86\%). [a] ${ }_{\mathrm{D}}^{25}-16(1.1, \mathrm{MeOH})$; IR (thin film): 2954, 2755, 2669, 2538, 1724, 1409, 1165, 1107, 1019, $786 \mathrm{~cm}^{-1} ;{ }^{1} \mathrm{H}$ NMR (400 MHz, DMSO- $\left.d_{6}\right) \delta=1.88-2.11(\mathrm{~m}, 2 \mathrm{H}), 2.11-2.26(\mathrm{~m}, 1 \mathrm{H})$, 2.27-2.41 (m, 1H), $2.56(\mathrm{~s}, 3 \mathrm{H}), 3.25(\mathrm{t}, J=7.3 \mathrm{~Hz}, 2 \mathrm{H}), 4.79(\mathrm{t}$, $J=7.8 \mathrm{~Hz}, 1 \mathrm{H}), 9.67(\mathrm{~s}, 1 \mathrm{H}), 10.62(\mathrm{~s}, 1 \mathrm{H}) ;{ }^{13} \mathrm{C}$ NMR (75 MHz, DMSO) $\delta=11.9,23.4,28.4,45.1,53.8,127.8,156.6,156.9,162.6$; HRMS $\left(\mathrm{ESI}^{+}\right.$) calcd for $\mathrm{C}_{9} \mathrm{H}_{12} \mathrm{~N}_{2} \mathrm{O}_{3}[\mathrm{M}+\mathrm{H}] 197.0921$, found 197.0925 .

\subsection{4. tert-Butyl (2S)-2-[(3-hydroxy-1-methoxy-1-oxopropan-2- yl)carbamoyl]pyrrolidine-1-carboxylate (9a)}

$\mathrm{N}$-Boc-I-proline $\mathbf{1 a}(4.00 \mathrm{~g}, 18.6 \mathrm{mmol}), \mathrm{I}$-serine methyl ester $\mathbf{8}$ $(3.18 \mathrm{~g}, 20.4 \mathrm{mmol})$ and HOBt $(4.27 \mathrm{~g}, 27.9 \mathrm{mmol})$ were added to a $500 \mathrm{~mL}$ round bottom flask with stir bar and dissolved in DCM $(150 \mathrm{~mL})$. DIPEA (7.95 mL, $46.5 \mathrm{mmol}$ ) was then added by syringe, followed by $\mathrm{EDC}-\mathrm{HCl}(5.34 \mathrm{~g}, 27.9 \mathrm{mmol})$. The reaction was stirred at room temperature for $48 \mathrm{~h}$, then the reaction was transferred to a separatory funnel and washed with water $(\sim 125 \mathrm{~mL}), 1 \mathrm{M} \mathrm{HCl}$ $(\sim 125 \mathrm{~mL})$, then saturated sodium bicarbonate $(\sim 125 \mathrm{~mL})$. The organic portion was dried with sodium sulfate, filtered, and concentrated to a white foam. The crude compound was dissolved in DCM ( $10 \mathrm{~mL})$ and purified by flash chromatography (100 $\mathrm{g} \mathrm{SiO}_{2}$ cartridge; $0-10 \% \mathrm{MeOH} / \mathrm{DCM}$ gradient) to yield the title compound $(5.08 \mathrm{~g}, 86 \%)$ as a white foam. This compound has been previously reported and characterized (CAS\# 955401-52-2). ${ }^{1} \mathrm{H}$ NMR $(300 \mathrm{MHz}$, $\left.\mathrm{CDCl}_{3}\right) \delta=1.45(\mathrm{~s}, 9 \mathrm{H}), 1.68(\mathrm{~s}, 1 \mathrm{H}), 1.89$ (br), $2.06(\mathrm{br}), 2.18$ (br), 3.47 (br), 3.80 (s, 3 H), 3.89 (br), 4.03 (br), 4.18 (br), 4.62 (br m, $1 \mathrm{H}), 7.06$ (br).

Tetrahedron, Vol 72, No. 27-28 (July 7, 2016): pg. 3905-3916. DOI. This article is @ Elsevier and permission has been granted for this version to appear in e-Publications@Marquette. Elsevier does not grant permission for this article to be further copied/distributed or hosted elsewhere without the express permission from Elsevier. 
NOT THE PUBLISHED VERSION; this is the author's final, peer-reviewed manuscript. The published version may be accessed by following the link in the citation at the bottom of the page.

\subsubsection{Methyl 2-[(2S)-1-[(tert-butoxy)carbonyl]pyrrolidin-2-yl]- 1,3-oxazole-4-carboxylate (10a)}

Dipeptide 9a ( $3.42 \mathrm{~g}, 10.8 \mathrm{mmol}$ ) was added to a $250 \mathrm{~mL}$ flask with stir bar and sealed under nitrogen, then DCM $(120 \mathrm{~mL})$ was added, and the solution was cooled to $-20^{\circ} \mathrm{C}$. Deoxo-Fluor $(2.12 \mathrm{~mL}$, $11.9 \mathrm{mmol}$ ) was added via syringe, and the reactions was stirred for $45 \mathrm{~min}$ at $-20^{\circ} \mathrm{C}$. The reaction was then quenched with saturated aqueous sodium bicarbonate $(\sim 30 \mathrm{~mL})$. The organic portion was dried with sodium sulfate, filtered, and concentrated and dried under high vacuum. The crude material was redissolved in DCM $(120 \mathrm{~mL})$ and cooled to $0^{\circ} \mathrm{C}$ in an ice bath. Bromotrichloromethane $(3.94 \mathrm{~mL}$, $40.0 \mathrm{mmol}$ ) was added via syringe, followed by DBU $(5.16 \mathrm{~mL}$, $40.0 \mathrm{mmol}$ ), which was added dropwise over $\sim 5 \mathrm{~min}$. The reaction was removed from the ice bath and allowed to warm to room temperature while stirring overnight. Water $(100 \mathrm{~mL})$ was added to the solution, then the mixture was extracted with EtOAc $(\times 3)$ in a separatory funnel. The combined organics were dried with sodium sulfate, filtered, and concentrated to a dark brown oil. The crude was purified by flash chromatography (100 $\mathrm{g} \mathrm{SiO}_{2}$ cartridge; $0-100 \%$ EtOAc/hexanes gradient) to yield the title compound $(2.51 \mathrm{~g}, 78 \%)$ as a white foam. This compound has been previously reported and characterized (CAS\# 955401-52-2). ${ }^{1} \mathrm{H}$ NMR $\left(300 \mathrm{MHz}, \mathrm{CDCl}_{3}\right) \delta=1.22-1.46$ (comp, $\left.9 \mathrm{H}\right)$, 1.86-2.01 (m, $1 \mathrm{H}), 2.03-2.20(\mathrm{comp}, 2 \mathrm{H}), 2.24-2.45(\mathrm{~m}, 1 \mathrm{H})$, 3.44-3.68 (comp, $2 \mathrm{H}$ ), 3.84-3.98 (comp, $3 \mathrm{H}$ ), 4.89-5.07 (comp, $1 \mathrm{H}), 8.18(\mathrm{~s}, 1 \mathrm{H})$.

\subsubsection{2-[(2S)-1-[(tert-Butoxy)carbonyl]pyrrolidin-2-yl]-1,3- oxazole-4-carboxylic acid (11a)}

Ester 10a $(2.48 \mathrm{~g}, 8.37 \mathrm{mmol})$ was added to a $50 \mathrm{~mL}$ flask with stir bar along with THF $(25 \mathrm{~mL})$ and water $(8 \mathrm{~mL})$. LiOH $(261 \mathrm{mg}$, $17.6 \mathrm{mmol}$ ) was added and the flask was stirred for $24 \mathrm{~h}$, after which time TLC analysis ( $10 \% \mathrm{MeOH} / \mathrm{DCM})$ indicated that the reaction was complete. The reaction was diluted with DCM $(\sim 75 \mathrm{~mL})$ and water $(\sim 75 \mathrm{~mL})$, then the $\mathrm{pH}$ was adjusted to 4 with $2 \mathrm{M}$ aq $\mathrm{HCl}$. The layers were separated and the aqueous phase was re-extracted with DCM $(2 \times 50 \mathrm{~mL})$. The combined organics were then dried with sodium sulfate, filtered, and concentrated to yield the title compound $(1.23 \mathrm{~g}$,

Tetrahedron, Vol 72, No. 27-28 (July 7, 2016): pg. 3905-3916. DOI. This article is (C Elsevier and permission has been granted for this version to appear in e-Publications@Marquette. Elsevier does not grant permission for this article to be further copied/distributed or hosted elsewhere without the express permission from Elsevier. 
94\%) as an off-white foam. This compound has been previously reported and characterized (CAS\# 1511857-57-0). ${ }^{1} \mathrm{H}$ NMR (300 MHz, $\left.\mathrm{CD}_{3} \mathrm{OD}\right) \delta=1.27$ (rotamer 1$) ; 1.44$ (rotamer 2$)(9 \mathrm{H}), 1.90-2.16$ (comp, $3 \mathrm{H}), 2.37(\mathrm{~m}, 1 \mathrm{H}), 3.49(\mathrm{~m}, 1 \mathrm{H}), 3.59(\mathrm{~m}, 1 \mathrm{H}), 4.94(\mathrm{~m}$, $2 \mathrm{H}), 8.47$ (s, $1 \mathrm{H}$ ). IR (thin film) 3435, 2978, 2537, 1685, 1585, 1406, $1250,1611,1113,982 \mathrm{~cm}^{-1}$.

4.2.7. tert-Butyl (2S,4R)-4-(benzyloxy)-2-[(3-hydroxy-1methoxy-1-oxopropan-2-yl)carbamoyl] pyrrolidine-1-carboxylate (9b)

Benzyloxy-proline 1b $(5.20 \mathrm{~g}, 16.2 \mathrm{mmol})$, l-serine methyl ester 8 (2.77 g, $17.8 \mathrm{mmol})$ and HOBt $(3.72 \mathrm{~g}, 24.3 \mathrm{mmol})$ were added to flask with stir bar and dissolved in DCM $(150 \mathrm{~mL})$. DIPEA $(6.93 \mathrm{~mL}$, $40.5 \mathrm{mmol}$ ) was then added by syringe, followed by $\mathrm{EDC}-\mathrm{HCl}(4.65 \mathrm{~g}$, $24.3 \mathrm{mmol}$ ). The reaction was stirred at room temperature for $48 \mathrm{~h}$, then the reaction was washed with water $(\sim 125 \mathrm{~mL}), 1 \mathrm{M} \mathrm{HCl}$ $(\sim 125 \mathrm{~mL})$, then saturated sodium bicarbonate $(\sim 125 \mathrm{~mL})$. The organic portion was dried with sodium sulfate, filtered, and concentrated to a white foam. The crude compound was dissolved in DCM ( $10 \mathrm{~mL})$ and purified by flash chromatography (100 $\mathrm{g} \mathrm{SiO}_{2}$ cartridge; $0-10 \% \mathrm{MeOH} / \mathrm{DCM}$ gradient) to yield the title compound $(6.45 \mathrm{~g}, 94 \%)$ as a white foam. [a] ${ }_{\mathrm{D}}^{20}+75(0.010, \mathrm{DCM}) ;$ IR (thin film): 3421.0, 2976.9, 1746.3, 1668.8, 1525.8, 1392.9, 1206.3, $1160.6,1068.7,909.5 \mathrm{~cm}^{-1} ;{ }^{1} \mathrm{H}$ NMR $\left(400 \mathrm{MHz} \mathrm{CDCl}_{3}\right) \delta \mathrm{ppm} 1.47(\mathrm{~s}$, $9 \mathrm{H}) 2.25(\mathrm{~s}, 1 \mathrm{H}) 2.29(\mathrm{~d}, \mathrm{~J}=5.9 \mathrm{~Hz}, 1 \mathrm{H}) 3.24-3.49(\mathrm{~m}, 1 \mathrm{H}) 3.57$ (br, $1 \mathrm{H}) 3.67(\mathrm{br}, 1 \mathrm{H}) 3.78(\mathrm{~s}, 2 \mathrm{H}) 3.85(\mathrm{br}, 2 \mathrm{H}) 4.12(\mathrm{br}, 2 \mathrm{H})$ 4.18-4.28 (m, $1 \mathrm{H}) 4.32(\mathrm{t}, \mathrm{J}=7.4 \mathrm{~Hz}, 1 \mathrm{H}) 4.45-4.57(\mathrm{~m}, 2 \mathrm{H}) 4.62$ (br, $1 \mathrm{H})$ 6.95-7.11 (m, $1 \mathrm{H}) 7.21-7.40(\mathrm{~m}, 5 \mathrm{H}) ;{ }^{13} \mathrm{C}$ NMR $(75 \mathrm{MHz}$, $\left.\mathrm{CDCl}_{3}\right) \delta=21.3,28.53,35.1,52.9,55.6,59.6,62.3,70.6,71.3,81.16$, $127.83,127.92,128.1,128.6,128.7,137.8,155.4,171.0,171.4$, 172.1; HRMS $\left(\mathrm{ESI}^{+}\right)$calcd for $\mathrm{C}_{21} \mathrm{H}_{30} \mathrm{~N}_{2} \mathrm{O}_{7}[\mathrm{M}+\mathrm{H}]$ 423.2125, found 423.2120 .

Tetrahedron, Vol 72, No. 27-28 (July 7, 2016): pg. 3905-3916. DOI. This article is @ Elsevier and permission has been granted for this version to appear in e-Publications@Marquette. Elsevier does not grant permission for this article to be further copied/distributed or hosted elsewhere without the express permission from Elsevier. 
4.2.8. Methyl 2-[(2S,4R)-4-(benzyloxy)-1-[(tertbutoxy)carbonyl]pyrrolidin-2-yl]-1,3-oxazole-4-carboxylate (10b)

Dipeptide 9b ( $3.13 \mathrm{~g}, 7.41 \mathrm{mmol}$ ) was added to a $250 \mathrm{~mL}$ flask with stir bar and sealed under nitrogen, then DCM $(120 \mathrm{~mL})$ was added, and the solution was cooled to $-20^{\circ} \mathrm{C}$. Deoxo-Fluor $(1.50 \mathrm{~mL}$, $8.18 \mathrm{mmol}$ ) was added via syringe, and the reactions was stirred for $45 \mathrm{~min}$ at $-20^{\circ} \mathrm{C}$. The reaction was then quenched with saturated aqueous sodium bicarbonate $(\sim 30 \mathrm{~mL})$. The organic portion was dried with sodium sulfate, filtered, and concentrated and dried under high vacuum. The crude material was dissolved in DCM $(120 \mathrm{~mL})$ and cooled to $0^{\circ} \mathrm{C}$ in an ice bath. Bromotrichloromethane $(3.94 \mathrm{~mL}$, $40.0 \mathrm{mmol}$ ) was added via syringe, followed by DBU $(5.16 \mathrm{~mL}$, $40.0 \mathrm{mmol}$ ), which was added dropwise over $5 \mathrm{~min}$. The reaction was removed from the ice bath and allowed to warm to room temperature while stirring overnight. Water $(100 \mathrm{~mL})$ was added to the solution, then the mixture was extracted with EtOAc $(\times 3)$. The combined organics were dried with sodium sulfate, filtered, and concentrated to a dark brown oil. The crude was purified by flash chromatography (100 $\mathrm{g} \mathrm{SiO}_{2}$ cartridge; $0-100 \%$ EtOAc/hexanes gradient) to yield the title compound $(1.37 \mathrm{~g}, 46 \%)$ as a colorless oil. [a] ${ }^{25}-81(0.029$, DCM); IR (thin film): 2976.5, 1744.3, 1697.7, 1583.7, 1393.2, $1366.4,1160.8,1109.9,1001.9 \mathrm{~cm}^{-1} ;{ }^{1} \mathrm{H}$ NMR $\left(400 \mathrm{MHz}, \mathrm{CDCl}_{3}\right)$ $\delta=1.21-1.35(\mathrm{~m}, 6 \mathrm{H}), 1.40-1.48(\mathrm{~m}, 4 \mathrm{H}), 2.22-2.39(\mathrm{~m}, 1 \mathrm{H}), 2.50$ (br, $1 \mathrm{H}), 3.69$ (dd, J=11.5, $4.5 \mathrm{~Hz}, 1 \mathrm{H}), 3.88-3.95(\mathrm{~m}, 3 \mathrm{H})$, 4.20-4.32 (m, $1 \mathrm{H}), 4.47-4.61(\mathrm{~m}, 2 \mathrm{H}), 5.03-5.17(\mathrm{~m}, 1 \mathrm{H})$, 7.28-7.41 (m, $3 \mathrm{H}), 8.07-8.20(\mathrm{~m}, 1 \mathrm{H}) ;{ }^{13} \mathrm{C} \mathrm{NMR}\left(75 \mathrm{MHz}, \mathrm{CDCl}_{3}\right)$ $\delta=28.4,28.6,38.8,53.9,71.3,76.0,80.6,127.9,128.1,128.8$, 143.6; HRMS $\left(\mathrm{ESI}^{+}\right)$calcd for $\mathrm{C}_{21} \mathrm{H}_{26} \mathrm{~N}_{2} \mathrm{O}_{6}[\mathrm{M}+\mathrm{H}] 403.1860$, found 423.1864 .

4.2.9. 2-[(2S,4R)-4-(Benzyloxy)-1-[(tertbutoxy)carbonyl]pyrrolidin-2-yl]-1,3-oxazole-4-carboxylic acid (11b)

Ester $10 \mathrm{~b}(1.68 \mathrm{~g}, 4.18 \mathrm{mmol})$ was added to a $50 \mathrm{~mL}$ flask with stir bar along with THF $(25 \mathrm{~mL})$ and water $(8 \mathrm{~mL})$. LiOH $(210 \mathrm{mg}$, $8.77 \mathrm{mmol}$ ) was added and the flask was stirred for $24 \mathrm{~h}$, after which

Tetrahedron, Vol 72, No. 27-28 (July 7, 2016): pg. 3905-3916. DOI. This article is (C) Elsevier and permission has been granted for this version to appear in e-Publications@Marquette. Elsevier does not grant permission for this article to be further copied/distributed or hosted elsewhere without the express permission from Elsevier. 
time TLC analysis (10\% MeOH/DCM) indicated that the reaction was complete. The reaction was diluted with DCM $(\sim 75 \mathrm{~mL})$ and water $(\sim 75 \mathrm{~mL})$, then the $\mathrm{pH}$ was adjusted to 4 with $2 \mathrm{M}$ aq $\mathrm{HCl}$. The layers were separated and the aqueous phase was re-extracted with DCM $(2 \times 50 \mathrm{~mL})$. The combined organics were then dried with sodium sulfate, filtered, and concentrated to yield the title compound $(1.61 \mathrm{~g}$, $90 \%)$ as an off-white foam. This compound was moved forward without further characterization.

\subsubsection{2-[(2S,4R)-4-(Benzyloxy)pyrrolidin-2-yl]-1,3-oxazole-4- carboxylic acid (12b)}

Carboxylic acid $\mathbf{1 1 b}(0.723 \mathrm{~g}, 1.85 \mathrm{mmol})$ was added to a $50 \mathrm{~mL}$ flask with stir bar and dissolved in DCM $(\sim 5 \mathrm{~mL}) .4 \mathrm{M} \mathrm{HCl}$ in dioxane (4.62 mL, $18.5 \mathrm{mmol})$ was added and the flask was stirred for $24 \mathrm{~h}$. The resulting slurry was filtered through paper and rinsed with hexanes. The white solid was moved to a $25 \mathrm{~mL}$ flask, dissolved in water $(\sim 5 \mathrm{~mL})$, and $30 \%$ aqueous ammonium hydroxide $(1 \mathrm{~mL})$ was added and stirred for $5 \mathrm{~min} 2 \mathrm{M} \mathrm{HCl}$ was then added until the $\mathrm{pH}$ was neutral. The solution was then extracted with DCM $(3 \times 10 \mathrm{~mL})$, and the combined organics were concentrated to yield the title compound $(0.41 \mathrm{~g}, 76 \%)$ as a colorless oil. [a] ${ }_{\mathrm{D}}^{25}+77(0.023, \mathrm{DCM})$; IR (thin film): 2931.1, 1583.0, 1495.6, 1453.9, 1384.9, 1249.3, 1215.4, 1093.7, 1027.4, $907.9 \mathrm{~cm}^{-1} ;{ }^{1} \mathrm{H}$ NMR (300 MHz, CD $\left.{ }_{3} \mathrm{OD}\right) \delta=2.56$ (ddd, $J=14.2,10.4,4.4 \mathrm{~Hz}, 1 \mathrm{H}), 2.81(\mathrm{dd}, J=14.1,6.7 \mathrm{~Hz}, 1 \mathrm{H}), 3.55-3.69$ $(\mathrm{m}, 2 \mathrm{H}), 4.52-4.57(\mathrm{~m}, 1 \mathrm{H}), 4.57-4.69(\mathrm{~m}, 2 \mathrm{H}), 5.15$ (dd, J=10.9, $7.0 \mathrm{~Hz}, 1 \mathrm{H}) 7.21-7.49(\mathrm{~m}, 5 \mathrm{H}), 8.64(\mathrm{~s}, 1 \mathrm{H}) ;{ }^{13} \mathrm{C} \mathrm{NMR}(75 \mathrm{MHz}$, $\left.\mathrm{CD}_{3} \mathrm{OD}\right) \delta=35.2,51.3,54.0,71.076 .8,127.8,127.9,128.4,134.16$, $137.6,159.4,162.3$; HRMS $\left(\mathrm{ESI}^{+}\right)$calcd for $\mathrm{C}_{15} \mathrm{H}_{16} \mathrm{~N}_{2} \mathrm{O}_{4}[\mathrm{M}+\mathrm{H}]$ 289.1183 , found 289.1186 .

\subsubsection{Methyl 2-[(1S)-1-\{[(tert-butoxy)carbonyl]amino $\}-2-$ methylpropyl]-1,3-oxazole-4-carboxylate (13)}

Dipeptide 12c $(6.50 \mathrm{~g}, 20.5 \mathrm{mmol})$ was added to a $500 \mathrm{~mL}$ flask with stir bar and sealed under nitrogen, then DCM $(200 \mathrm{~mL})$ was added, and the solution was cooled to $-20^{\circ} \mathrm{C}$. Deoxo-Fluor $(4.14 \mathrm{~mL}$, $22.5 \mathrm{mmol}$ ) was added via syringe, and the reactions was stirred for $45 \mathrm{~min}$ at $-20^{\circ} \mathrm{C}$. The reaction was then quenched with saturated

Tetrahedron, Vol 72, No. 27-28 (July 7, 2016): pg. 3905-3916. DOI. This article is @ Elsevier and permission has been granted for this version to appear in e-Publications@Marquette. Elsevier does not grant permission for this article to be further copied/distributed or hosted elsewhere without the express permission from Elsevier. 
aqueous sodium bicarbonate $(\sim 70 \mathrm{~mL})$. The organic portion was dried with sodium sulfate, filtered, concentrated, and dried under high vacuum. The crude material was redissolved in DCM $(200 \mathrm{~mL})$ and cooled to $0{ }^{\circ} \mathrm{C}$ in an ice bath. Bromotrichloromethane $(7.44 \mathrm{~mL}$, $75.5 \mathrm{mmol})$ was added via syringe, followed by DBU $(9.75 \mathrm{~mL}$, $75.5 \mathrm{mmol}$ ), which was added dropwise over $5 \mathrm{~min}$. The reaction was removed from the ice bath and allowed to warm to room temperature while stirring overnight. Water $(200 \mathrm{~mL})$ was added to the solution, then the mixture was extracted with EtOAc $(\times 3)$. The combined organics were dried with sodium sulfate, filtered, and concentrated to a dark brown oil. The crude was purified by flash chromatography (100 $\mathrm{g} \mathrm{SiO}_{2}$ cartridge; $0-100 \%$ EtOAc/hexanes gradient) to yield the title compound $(6.09 \mathrm{~g}, 79 \%)$ as a white solid. This compound has been previously reported and characterized (CAS\# 158068-97-4). ${ }^{1} \mathrm{H}$ $\operatorname{NMR}\left(300 \mathrm{MHz} \mathrm{CDCl}_{3}\right) \delta=0.87-0.98(\mathrm{~m}, 6 \mathrm{H}), 1.44(\mathrm{~s}, 9 \mathrm{H})$, 2.10-2.29 (m, $1 \mathrm{H}), 3.92(\mathrm{~s}, 3 \mathrm{H}), 4.74-4.88(\mathrm{~m}, 1 \mathrm{H}), 5.28(\mathrm{~d}$, $J=7.2 \mathrm{~Hz}, 1 \mathrm{H}), 8.19(\mathrm{~s}, 1 \mathrm{H})$.

\subsubsection{2-[(1S)-1-\{[(tert-Butoxy)carbonyl](methyl)amino\}-2- methylpropyl]-1,3-oxazole-4-carboxylic acid (14)}

Ester $13(1.90 \mathrm{~g}, 6.13 \mathrm{mmol})$ was added to a $250 \mathrm{~mL}$ flask with stir bar along with THF (60 mL) and water $(5.6 \mathrm{~mL})$. LiOH $(306 \mathrm{mg}$, $12.3 \mathrm{mmol}$ ) was added and the flask was stirred for $24 \mathrm{~h}$, after which time TLC analysis (10\% MeOH/DCM) indicated that the reaction was complete. The reaction was diluted with DCM $(\sim 75 \mathrm{~mL})$ and water $(\sim 50 \mathrm{~mL})$, then the $\mathrm{pH}$ was adjusted to 4 with $2 \mathrm{M}$ aq $\mathrm{HCl}$. The layers were separated and the aqueous phase was re-extracted with DCM $(2 \times 50 \mathrm{~mL})$. The combined organics were then dried with sodium sulfate, filtered, and concentrated to yield the title compound ( $1.76 \mathrm{~g}$, $97 \%$ ) as a pale yellow solid. The compound was advanced without further purification. This compound has been previously reported and characterized (CAS\# 220717-54-4). ${ }^{1} \mathrm{H}$ NMR (300 MHz, CDCl $) \delta=0.94$ $(\mathrm{s}, 6 \mathrm{H}), 1.42(\mathrm{~s}, 9 \mathrm{H}), 1.86(\mathrm{~s}, 1 \mathrm{H}), 2.21(\mathrm{~s}, 1 \mathrm{H}), 3.76(\mathrm{~s}, 1 \mathrm{H}), 4.82$ (br, $1 \mathrm{H}), 5.92(\mathrm{br}, 1 \mathrm{H}), 8.29(\mathrm{~s}, 1 \mathrm{H})$.

Tetrahedron, Vol 72, No. 27-28 (July 7, 2016): pg. 3905-3916. DOI. This article is @ Elsevier and permission has been granted for this version to appear in e-Publications@Marquette. Elsevier does not grant permission for this article to be further copied/distributed or hosted elsewhere without the express permission from Elsevier. 


\subsection{Representative procedure $A$ (for valine-based secondary and tertiary amides) (Scheme 6)}

\subsection{1. tert-Butyl N-[(1S)-2-methyl-1-\{4-[(4- methylphenyl)carbamoyl]-1,3-oxazol-2yl\}propyl] carbamate (14a)}

Carboxylic acid $14(0.505 \mathrm{~g}, 1.76 \mathrm{mmol})$ was dissolved in DCE $(8 \mathrm{~mL})$, and 4-methylaniline $(0.191 \mathrm{~g}, 1.76 \mathrm{mmol})$ and PyBOP $(1.10 \mathrm{~g}$, $2.11 \mathrm{mmol})$ were added to the solution. DIPEA $(0.763 \mathrm{~mL}, 4.40 \mathrm{mmol})$ was added and the reaction was stirred for $3 \mathrm{~h}$. The solution was diluted with DCM ( $20 \mathrm{~mL})$. The reaction solution was washed with $2 \mathrm{M}$ $\mathrm{HCl}(25 \mathrm{~mL})$, then half-saturated aqueous sodium bicarbonate $(25 \mathrm{~mL})$. The organic layer was then dried with sodium sulfate and concentrated. The crude was purified by flash chromatography $(50 \mathrm{~g}$ $\mathrm{SiO}_{2}$ cartridge; $0-100 \%$ EtOAc/hexanes gradient) to yield the title compound as a colorless oil $(0.510 \mathrm{~g}, 78 \%)$. [a] $\mathrm{D}^{25}+77(0.094, \mathrm{DCM})$; IR (thin film): 3322.9, 2969.9, 1676.5, 1600.8, 1520.6, 1456.3, $1391.8,1239.9,1163.1,1099.5 \mathrm{~cm}^{-1} ;{ }^{1} \mathrm{H}$ NMR (300 $\left.\mathrm{MHz}_{1} \mathrm{CDCl}_{3}\right)$ $\delta=0.97(\mathrm{~d}, J=8.5 \mathrm{~Hz}, 3 \mathrm{H}), 0.95(\mathrm{~d}, J=8.2 \mathrm{~Hz}, 3 \mathrm{H}), 1.47(\mathrm{~s}, 9 \mathrm{H})$, 2.11-2.28 (m, $1 \mathrm{H}), 2.34(\mathrm{~s}, 3 \mathrm{H}), 3.82-3.89(\mathrm{~m}, 1 \mathrm{H}), 4.75-4.86$, $(\mathrm{m}, 2 \mathrm{H}) 5.16,(\mathrm{~d}, J=8.8 \mathrm{~Hz}, 1 \mathrm{H}), 7.17(\mathrm{~d}, J=8.2 \mathrm{~Hz}, 2 \mathrm{H}), 7.42$ (ddd, $J=8.4,7.1,1.1 \mathrm{~Hz}, 1 \mathrm{H}$ ), 7.54-7.60 (m, 2 H), 7.66-7.74 (rotamer 1, $\mathrm{dt} J=8.4,1.1 \mathrm{~Hz}, 0.5 \mathrm{H}$ ), 8.03 (rotamer $2, \mathrm{dt}, J=8.4,1.1 \mathrm{~Hz}, 0.5 \mathrm{H}$ ), $8.22(\mathrm{~s}, 1 \mathrm{H}), 8.61(\mathrm{~s}, 1 \mathrm{H}) ;{ }^{13} \mathrm{C} \mathrm{NMR}\left(75 \mathrm{MHz}, \mathrm{CDCl}_{3}\right) \delta=18.3,18.9$, $21.2,28.6,32.9,40.4,54.6,79.8,108.9,120.1,120.5,125.1,128.6$, $129.8,134.4,135.0,136.5,141.6,158.3$; HRMS $\left(\mathrm{ESI}^{+}\right)$calcd for $\mathrm{C}_{20} \mathrm{H}_{27} \mathrm{~N}_{3} \mathrm{O}_{4}[\mathrm{M}+\mathrm{H}]$ 374.2074, found 374.2074.
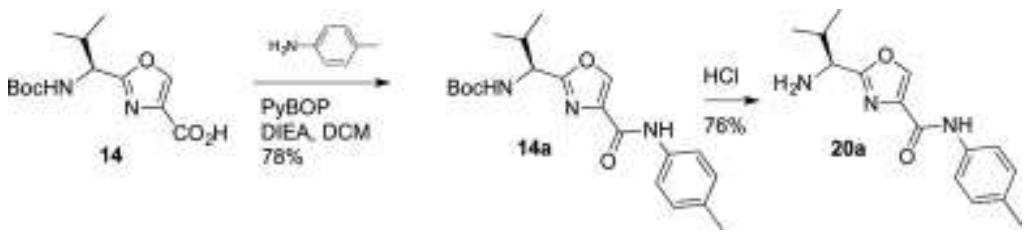

Scheme 6. Synthesis of carboxamide precatalyst 20a.

Tetrahedron, Vol 72, No. 27-28 (July 7, 2016): pg. 3905-3916. DOI. This article is (c) Elsevier and permission has been granted for this version to appear in e-Publications@Marquette. Elsevier does not grant permission for this article to be further copied/distributed or hosted elsewhere without the express permission from Elsevier. 


\subsubsection{2-[(1S)-1-Amino-2-methylpropyl]-N-(4-methylphenyl)- 1,3-oxazole-4-carboxamide (20a)}

Carbamate $14 a(0.72 \mathrm{~g}, 1.85 \mathrm{mmol})$ was added to a $50 \mathrm{~mL}$ flask with stir bar and dissolved in DCM $(\sim 5 \mathrm{~mL}) .4 \mathrm{M} \mathrm{HCl}$ in dioxane $(4.62 \mathrm{~mL}, 18.5 \mathrm{mmol})$ was added and the flask was stirred for $24 \mathrm{~h}$. The resulting slurry was filtered through paper and rinsed with hexanes. The white solid was moved to a $25 \mathrm{~mL}$ flask, dissolved in water $(\sim 5 \mathrm{~mL})$, and $30 \%$ aqueous ammonium hydroxide $(1 \mathrm{~mL})$ was added and stirred for 5 min $2 \mathrm{M} \mathrm{HCl}$ was then added until the $\mathrm{pH}$ was neutral. The solution was then extracted with DCM $(3 \times 10 \mathrm{~mL})$. The combined organics were concentrated to yield the title compound as an off-white solid $(0.41 \mathrm{~g}, 76 \%)$. mp $140-144{ }^{\circ} \mathrm{C}$. [a] $]_{\mathrm{D}}^{25}+134(0.013$, DCM); IR (thin film): 2958.9, 1657.9, 1598.4, 1520.4, 1466.1, $1318.2,1090.1,914.6,815.5 \mathrm{~cm}^{-1} ;{ }^{1} \mathrm{H}$ NMR $\left(300 \mathrm{MHz}, \mathrm{CDCl}_{3}\right) \delta=0.97$ (dd, J=6.7, $4.10 \mathrm{~Hz}, 6 \mathrm{H}), 1.72(\mathrm{~s}, 2 \mathrm{H}), 2.06-2.23(\mathrm{~m}, 1 \mathrm{H}), 2.33(\mathrm{~s}$, $3 \mathrm{H}), 3.59-3.80(\mathrm{~m}, 1 \mathrm{H}), 3.90(\mathrm{~d}, J=5.9 \mathrm{~Hz}, 1 \mathrm{H}), 7.17(\mathrm{~d}, J=7.9 \mathrm{~Hz}$, $2 \mathrm{H}), 7.54-7.61(\mathrm{~m}, 2 \mathrm{H}), 8.22(\mathrm{~s}, 1 \mathrm{H}), 8.66(\mathrm{br}, 1 \mathrm{H}) ;{ }^{13} \mathrm{C} \mathrm{NMR}$ (75 MHz, $\left.\mathrm{CDCl}_{3}\right) \delta=18.0,19.2,21.1,33.8,56.1,120.0,129.8,134.4$, $135.1,136.4,141.5,158.6,167.2$; HRMS $\left(\right.$ ESI $\left.^{+}\right)$calcd for $\mathrm{C}_{15} \mathrm{H}_{19} \mathrm{~N}_{3} \mathrm{O}_{2}$ $[\mathrm{M}+\mathrm{H}] 274.1550$, found 274.1546 .

\subsection{Representative procedure B (for primary amides) (Scheme 7)}

\subsubsection{Methyl 2-[(1S)-1-\{[(tert-butoxy)carbonyl]amino $\}-2-$ methylpropyl]-1,3-oxazole-4-carboxylate (14b)}

$7 \mathrm{~N}$ Ammonia in methanol $(6.0 \mathrm{~mL}, 42.2 \mathrm{mmol})$ was added to DCM $(60 \mathrm{~mL})$. Ester $14(0.40 \mathrm{~g}, 1.40 \mathrm{mmol})$ was added to the ammonia solution and stirred for $16 \mathrm{~h}$, after which time LC-MS analysis indicated that the reaction was complete. The reaction solution was then washed with water $(3 \times 25 \mathrm{~mL})$, dried with sodium sulfate, and concentrated. The crude oil was purified by flash chromatography (50 $\mathrm{g} \mathrm{SiO}_{2}$ cartridge; $0-10 \% \mathrm{MeOH} / \mathrm{DCM}$ gradient) to yield the title compound $(0.48 \mathrm{~g}, 86 \%)$ as a colorless oil. This compound was moved forward without further characterization.

Tetrahedron, Vol 72, No. 27-28 (July 7, 2016): pg. 3905-3916. DOI. This article is @ Elsevier and permission has been granted for this version to appear in e-Publications@Marquette. Elsevier does not grant permission for this article to be further copied/distributed or hosted elsewhere without the express permission from Elsevier. 


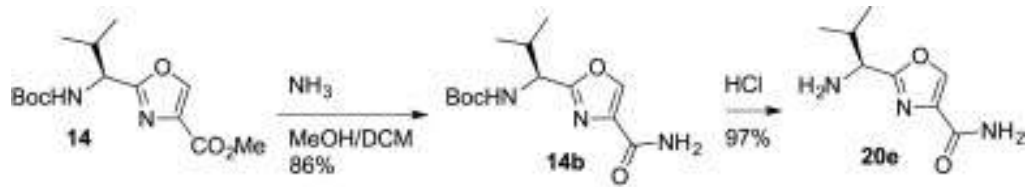

Scheme 7. Synthesis of carboxamide precatalyst $\mathbf{2 0 e .}$

\subsubsection{2-[(1S)-1-Amino-2-methylpropyl]-1,3-oxazole-4- carboxamide (20e)}

Carbamate 14b $(0.33 \mathrm{~g}, 1.15 \mathrm{mmol})$ was added to a $25 \mathrm{~mL}$ flask with stir bar and dissolved in DCM $(5 \mathrm{~mL}) .4 \mathrm{M} \mathrm{HCl}$ in dioxane $(1.44 \mathrm{~mL}, 5.77 \mathrm{mmol}$ ) was added and the reaction was stirred for $24 \mathrm{~h}$. The solvent was evaporated by blowing nitrogen gas through the flask, then the crude solid was dissolved in water $(\sim 5 \mathrm{~mL})$, and $30 \%$ aqueous ammonium hydroxide $(0.20 \mathrm{~mL})$ was added and stirred for 5 min $2 \mathrm{M} \mathrm{HCl}$ was then added until the $\mathrm{pH}$ was neutral. The mixture was then extracted with DCM $(3 \times 10 \mathrm{~mL})$. The combined organics were concentrated to yield the title compound as an off-white solid $(0.21 \mathrm{~g}$, 97\%). mp 240-245 ${ }^{\circ} \mathrm{C}$; [a] ${ }^{25}-18$ (0.012, DCM); IR (thin film): 3101.5, 2959.6, 1654.4, 1616.1, 1411.5, 1317.1, 1109.2, 987.9, 921.5, $864.9 \mathrm{~cm}^{-1} ;{ }^{1} \mathrm{H}$ NMR $\left(300 \mathrm{MHz}, \mathrm{CDCl}_{3}\right) \delta=0.95$ (dd, J=6.9, $4.25 \mathrm{~Hz}, 6 \mathrm{H}), 1.63(\mathrm{~s}, 3 \mathrm{H}), 2.04-2.21(\mathrm{~m}, 1 \mathrm{H}), 3.87(\mathrm{~d}, J=5.9 \mathrm{~Hz}$, $1 \mathrm{H}), 5.62(\mathrm{br}, 1 \mathrm{H}), 6.82(\mathrm{br}, 1 \mathrm{H}), 8.17(\mathrm{~s}, 1 \mathrm{H}) ;{ }^{13} \mathrm{C} \mathrm{NMR}(75 \mathrm{MHz}$, $\left.\mathrm{CDCl}_{3}\right) \delta=18.0,19.2,33.7,56.0,135.6,141.6,162.8,167.3$; HRMS $\left(\mathrm{ESI}^{+}\right.$) calcd for $\mathrm{C}_{8} \mathrm{H}_{13} \mathrm{~N}_{3} \mathrm{O}_{2}[\mathrm{M}+\mathrm{H}]$ 184.1081, found 184.1086.

\subsection{Representative procedure $C$ (for proline-based secondary and tertiary amides) (Scheme 8)}

\subsection{1. tert-Butyl (S)-2-(4-(p-tolylcarbamoyl)oxazol-2- yl)pyrrolidine-1-carboxylate (11c)}

Acid 11a (600 mg, $2.13 \mathrm{mmol}$ ) was added to a $20 \mathrm{~mL}$ reaction vial, followed by HOBt (586 mg, $3.83 \mathrm{mmol}$ ) 4-methylaniline $(273 \mathrm{mg}$, $2.55 \mathrm{mmol}), \mathrm{DCM}(15 \mathrm{~mL})$, and DIEA $(1.09 \mathrm{~mL}, 6.37 \mathrm{mmol})$. EDC-HCl (733.4 $\mathrm{mg}, 3.83 \mathrm{mmol}$ ) was then added to the vial and the mixture was stirred at room temperature for $16 \mathrm{~h}$. The reaction was diluted with DCM $(30 \mathrm{~mL})$ and washed with $0.1 \mathrm{~N} \mathrm{HCl}(50 \mathrm{~mL})$, saturated sodium bicarbonate $(50 \mathrm{~mL})$, and brine $(30 \mathrm{~mL})$. The organic layer was

Tetrahedron, Vol 72, No. 27-28 (July 7, 2016): pg. 3905-3916. DOI. This article is @ Elsevier and permission has been granted for this version to appear in e-Publications@Marquette. Elsevier does not grant permission for this article to be further copied/distributed or hosted elsewhere without the express permission from Elsevier. 
then dried over sodium sulfate and concentrated, and the crude material was purified by chromatography $\left(\mathrm{SiO}_{2}, 0-60 \%\right.$

EtOAc/hexanes) to give the title compound as a white solid (789 mg, $83 \%) . \mathrm{mp}=125-130{ }^{\circ} \mathrm{C} ; R_{f}\left(50 \%\right.$ EtOAc/hexanes) $0.60 ;[\mathrm{a}]_{\mathrm{D}}{ }^{25}-62$ (1.0, DCM); IR (thin film): 3360, 2975, 1686, 1599, 1512, 1364, $1101,876,666 \mathrm{~cm}^{-1} ;{ }^{1} \mathrm{H}$ NMR $\left(300 \mathrm{MHz} \mathrm{CDCl}_{3}\right) \delta=1.30(\mathrm{~s}, 6 \mathrm{H}), 1.46$ $(\mathrm{s}, 3 \mathrm{H}), 1.88-2.02(\mathrm{~m}, 1 \mathrm{H}), 2.04-2.18(\mathrm{~m}, 2 \mathrm{H}), 2.34(\mathrm{~s}, 4 \mathrm{H}), 3.22-$ $3.8(\mathrm{~m}, 2 \mathrm{H}), 4.85-5.07(\mathrm{~m}, 1 \mathrm{H}), 7.18(\mathrm{~d}, J=7.8 \mathrm{~Hz}, 2 \mathrm{H}), 7.57(\mathrm{~d}$, $J=8.2 \mathrm{~Hz}, 2 \mathrm{H}), 8.19(\mathrm{~s}, 1 \mathrm{H}), 8.62(\mathrm{~s}, 1 \mathrm{H}) ;{ }^{13} \mathrm{C} \mathrm{NMR}\left(75 \mathrm{MHz} \mathrm{CDCl}_{3}\right)$ $\delta=20.9,23.6,28.2,28.4,32.4,46.4,54.7,80.1,119.8,129.5,134.2$, $134.8,136.4,140.9,141.3,158.2,165.4$; $\mathrm{HRMS}\left(\mathrm{ESI}^{+}\right)$calcd for $\mathrm{C}_{20} \mathrm{H}_{25} \mathrm{~N}_{3} \mathrm{O}_{4}[\mathrm{M}+\mathrm{Na}] 394.1737$, found 394.1732 .

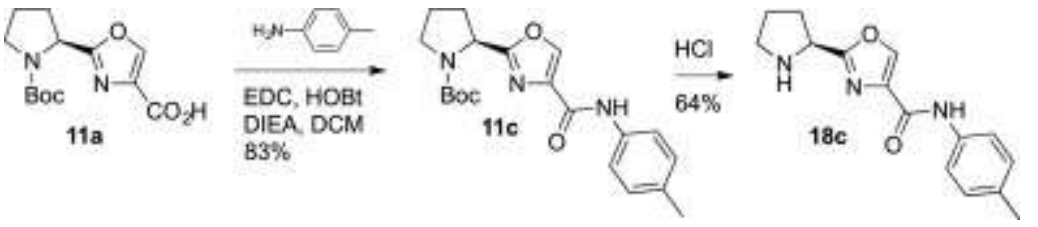

Scheme 8. Synthesis of carboxamide precatalyst $\mathbf{1 8 c}$.

\subsection{2. (S)-2-(Pyrrolidin-2-yI)-N-(p-tolyl)oxazole-4-carboxamide (18c)}

Carbamate 11c (555 mg, $1.50 \mathrm{mmol}$ ) was added to a $50 \mathrm{~mL}$ round bottom flask, followed by DCM $(20 \mathrm{~mL}) .4 \mathrm{M} \mathrm{HCl}$ in dioxane (9.30 $\mathrm{mL})$ was added, and the reaction was stirred for $3 \mathrm{~h}$. The reaction was diluted with $\mathrm{DCM}(50 \mathrm{~mL})$ and washed with satd aq $\mathrm{NaHCO}_{3}(300 \mathrm{~mL})$. The phases were separated, and the aqueous phase was extracted with DCM $(3 \times 50 \mathrm{~mL})$. The combined organics were dried over $\mathrm{Na}_{2} \mathrm{SO}_{4}$, concentrated to a crude oil, and purified by flash chromatography $\left(\mathrm{SiO}_{2}, 0-20 \% \mathrm{MeOH} / \mathrm{DCM}\right)$ to give the deprotected amine as a yellow solid (260 mg, 64\%). $\mathrm{mp}=65-70{ }^{\circ} \mathrm{C} ; R_{f}(10 \%$ $\mathrm{MeOH} / \mathrm{DCM})$ 0.29; [a] ${ }_{\mathrm{D}}^{20}-15(1.0, \mathrm{MeOH}) ; \mathrm{IR}$ (thin film): 3360, 2974, $1686,1662,1512,1101,816 \mathrm{~cm}^{-1} ;{ }^{1} \mathrm{H}$ NMR (300 MHz, CDCl 3 ) $\delta=1.83-2.01(\mathrm{~m}, 2 \mathrm{H}), 2.09$ (ddt, $J=12.3,7.7,6.2 \mathrm{~Hz}, 1 \mathrm{H}), 2.19-2.32$ $(\mathrm{m}, 2 \mathrm{H}), 2.34(\mathrm{~s}, 3 \mathrm{H}), 3.07$ (ddd, $J=10.2,7.5,6.2 \mathrm{~Hz}, 1 \mathrm{H}), 3.19$ (ddd, $J=10.0,7.2,6.0 \mathrm{~Hz}, 1 \mathrm{H}), 4.40(\mathrm{dd}, J=8.0,5.9 \mathrm{~Hz}, 1 \mathrm{H}), 7.17(\mathrm{~d}$, $J=8.3 \mathrm{~Hz}, 2 \mathrm{H}), 7.57(\mathrm{~d}, J=8.4 \mathrm{~Hz}, 2 \mathrm{H}), 8.21(\mathrm{~s}, 1 \mathrm{H}), 8.64(\mathrm{~s}, 1 \mathrm{H}) ;{ }^{13} \mathrm{C}$ NMR $\left(75 \mathrm{MHz}_{1} \mathrm{CDCl}_{3}\right) \delta=21.2,25.6,31.2,47.2,55.6,120.1,129.8$,

Tetrahedron, Vol 72, No. 27-28 (July 7, 2016): pg. 3905-3916. DOI. This article is @ Elsevier and permission has been granted for this version to appear in e-Publications@Marquette. Elsevier does not grant permission for this article to be further copied/distributed or hosted elsewhere without the express permission from Elsevier. 


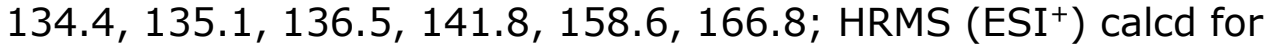
$\mathrm{C}_{15} \mathrm{H}_{17} \mathrm{~N}_{3} \mathrm{O}_{2}[\mathrm{M}+\mathrm{H}]$ 272.1394, found 272.1399.

\subsection{Representative procedure $D$ (synthesis of imidazole-phenols from azido-ketone 24)}

\subsubsection{1-(2-(Benzyloxy)phenyl)-2-bromoethan-1-one (22)}

O-hydroxyacetophenone $(5.00 \mathrm{~g}, 36.7 \mathrm{mmol}) \mathbf{2 1}$ was added to an oven-dried flask with a magnetic stir bar and sealed under nitrogen. Anhydrous DMF (15 mL) was added via syringe followed by sodium hydride (60\% dispersion in paraffin oil, $1.62 \mathrm{~g}, 40.4 \mathrm{mmol}$ ). The mixture was stirred at room temperature under nitrogen for $15 \mathrm{~min}$ before benzyl bromide $(5.05 \mathrm{~mL}, 40.4 \mathrm{mmol})$ was added dropwise via syringe. The reaction was left to stir under nitrogen for $16 \mathrm{~h}$. The reaction mixture was added to TBME $(300 \mathrm{~mL})$ and washed with saturated ammonium chloride $(2 \times 75 \mathrm{~mL})$, followed by water $(150 \mathrm{~mL})$ and brine $(150 \mathrm{~mL})$. The organic layer was then dried over sodium sulfate and concentrated to yield a pale yellow oil. The oil was purified by flash chromatography $\left(\mathrm{SiO}_{2}, 5 \%\right.$ TBME in hexanes) to afford the title compound as a colorless oil $(7.41 \mathrm{~g}, 89 \%)$. This compound has been previously reported and characterized (CAS\# 31165-67-0). ${ }^{1} \mathrm{H}$ NMR (300 MHz, $\left.\mathrm{CDCl}_{3}\right) \delta=2.62(\mathrm{~s}, 3 \mathrm{H}), 5.17(\mathrm{~s}, 2 \mathrm{H}), 6.91-7.84(\mathrm{~m}$, $9 \mathrm{H})$.

\subsubsection{1-[2-(Benzyloxy)phenyl]-2-bromoethan-1-one (23)}

Ketone 22 (7.40 g, $32.7 \mathrm{mmol})$ was placed in a $25 \mathrm{~mL}$ flask followed by PTSA (622 mg, $3.27 \mathrm{mmol}$ ) and NBS (6.40 g, $35.9 \mathrm{mmol}$ ) and the resulting slurry was stirred at room temperature for $16 \mathrm{~h}$. The reaction mixture was diluted with MTBE $(500 \mathrm{~mL})$ and washed with water $(2 \times 400 \mathrm{~mL})$ and brine $(400 \mathrm{~mL})$. The organic layer was then dried over sodium sulfate, filtered, and concentrated to yield a yellow oil. The oil was purified by flash chromatography $\left(\mathrm{SiO}_{2}, 5 \%\right.$ EtOAc in hexanes), and the resulting yellow oil was recrystallized from hot ethanol to afford the title compound as an off-white solid $(8.18 \mathrm{~g}$, $82 \%)$. This compound has been previously reported and characterized (CAS\# 56443-24-4). ${ }^{1} \mathrm{H}$ NMR (300 MHz, CDCl $) \delta 4.54(\mathrm{~s}, 2 \mathrm{H}), 5.19$ (s, $2 \mathrm{H}), 6.93-7.14(\mathrm{~m}, 2 \mathrm{H}), 7.31-7.57(\mathrm{~m}, 6 \mathrm{H}), 7.75-7.9(\mathrm{~m}, 1 \mathrm{H})$.

Tetrahedron, Vol 72, No. 27-28 (July 7, 2016): pg. 3905-3916. DOI. This article is @ Elsevier and permission has been granted for this version to appear in e-Publications@Marquette. Elsevier does not grant permission for this article to be further copied/distributed or hosted elsewhere without the express permission from Elsevier. 


\subsubsection{2-(2-(Benzyloxy)phenyl)-2-oxoethan-1-aminium chloride} (24)

Bromoketone $23(7.40 \mathrm{~g}, 24.25 \mathrm{mmol})$ was added to a $100 \mathrm{~mL}$ round bottom flask with a magnetic stir bar. Anhydrous DMF (40 mL) was added via syringe followed by sodium azide $(3.15 \mathrm{~g}, 48.5 \mathrm{mmol})$. The flask was fitted with a septum and flushed with nitrogen. The reaction was stirred at room temperature for $5 \mathrm{~h}$, after which time the mixture was diluted with EtOAc $(350 \mathrm{~mL})$ and washed with water $(3 \times 150 \mathrm{~mL})$ and brine $(150 \mathrm{~mL})$. The organic layer was then dried over sodium sulfate, filtered, and concentrated to afford an orange oil. The orange oil was dissolved with a 50:50 mixture of DCM and hexanes and purified by flash chromatography $\left(\mathrm{SiO}_{2}, 5-25 \%\right.$ EtOAc in hexanes) to give title compound as a pale yellow oil $(3.93 \mathrm{~g}, 60 \%) . R_{f}$ (10\% EtOAc in hexanes) 0.20; IR (thin film): 2101, 1678, 1596, 1483, $1449,1290,1234,1197,1163,1007,911,757 \mathrm{~cm}^{-1} ;{ }^{1} \mathrm{H}$ NMR $\left(300 \mathrm{MHz} \mathrm{CDCl}_{3}\right) \delta=4.44(\mathrm{~s}, 2 \mathrm{H}), 5.16(\mathrm{~s}, 2 \mathrm{H}), 7-7.15(\mathrm{~m}, 2 \mathrm{H}), 7.3-$ $7.46(\mathrm{~m}, 4 \mathrm{H}), 7.46-7.58(\mathrm{~m}, 1 \mathrm{H}), 7.93(\mathrm{dd}, J=8.0,1.9 \mathrm{~Hz}, 1 \mathrm{H}) ;{ }^{13} \mathrm{C}$ NMR $\left(75 \mathrm{MHz}_{1} \mathrm{CDCl}_{3}\right) \delta=59.7,71.2,113.0,121.6,125.1,128.0$, 128.9, 129.1, 131.4, 135.2, 135.7, 158.7, 194.6; HRMS (ESI ${ }^{+}$) calcd for $\mathrm{C}_{15} \mathrm{H}_{13} \mathrm{~N}_{3} \mathrm{O}_{2}[\mathrm{M}+\mathrm{H}] 290.0900$, found 290.0905 .

\subsection{4. (S)-2-(2-(1-Amino-2-phenylethyl)-1H-imidazol-4- yl)phenol (28b)}

Azide 24 (62.3 mg, $0.233 \mathrm{mmol}$ ) was dissolved in $\mathrm{MeOH}(5 \mathrm{~mL})$ in a $20 \mathrm{~mL}$ vial. Concentrated aqueous $\mathrm{HCl}(37 \%-12 \mathrm{~N})(39 \mu \mathrm{L}$, $0.47 \mathrm{mmol})$ was then added, followed by diphenyl sulfide $(0.39 \mu \mathrm{L}$, $0.0019 \mathrm{mmol})$. The flask was flushed with nitrogen, then $10 \% \mathrm{Pd} / \mathrm{C}$ (12.5 mg) was added. The flask was sealed with a septum and a balloon of hydrogen was placed on the flask. 1 balloon was allowed to bubble through the solution to displace the nitrogen, then the balloon was refilled and the reaction was stirred under hydrogen for $3 \mathrm{~h}$. The mixture was passed through a cake of Celite to remove the $\mathrm{Pd} / \mathrm{C}$ catalyst and concentrated to afford an off-white solid. This crude product was used directly in the next step without further purification.

The crude aminoketone $\mathbf{2 5}$ was dissolved in DCM ( $5 \mathrm{~mL}$ ) in a $20 \mathrm{~mL}$ vial, of Boc-protected amino acid $(0.233 \mathrm{mmol})$, and HOBt

Tetrahedron, Vol 72, No. 27-28 (July 7, 2016): pg. 3905-3916. DOI. This article is @ Elsevier and permission has been granted for this version to appear in e-Publications@Marquette. Elsevier does not grant permission for this article to be further copied/distributed or hosted elsewhere without the express permission from Elsevier. 
( $53.5 \mathrm{mg}, 0.350 \mathrm{mmol}$ ) were added. DIEA (79 uL, $0.466 \mathrm{mmol}$ ) was added via syringe. EDC- $\mathrm{HCl}(67.0 \mathrm{mg}, 0.350 \mathrm{mmol})$ was then added and the flask was stirred at room temperature overnight. The reaction with DCM $(10 \mathrm{~mL})$ and washed with $0.25 \mathrm{~N} \mathrm{HCl}(25 \mathrm{~mL})$, saturated sodium bicarbonate $(10 \mathrm{~mL})$, and brine $(10 \mathrm{~mL})$. The organic layer was then dried over sodium sulfate and concentrated to yield a yellow oil. The crude oil was dissolved in DCM and passed through a 5" Pasteur pipet packed with silica gel, then eluted with EtOAc. The organic phase was then concentrated to give the crude amide $\mathbf{2 6}$ as a colorless oil, which was used directly in the next step.

The crude amide $\mathbf{2 6}$ was dissolved in xylenes ( $5 \mathrm{~mL}$ ) in a $20 \mathrm{~mL}$ vial. Ammonium acetate ( $449 \mathrm{mg}, 5.83 \mathrm{mmol}$ ) was added and the vial was fitted with a drying tube. The reaction was heated at $135^{\circ} \mathrm{C}$ for $16 \mathrm{~h}$, after which time TLC showed complete consumption of the starting material. The reaction was concentrated, taken up in EtOAc, and passed through a 5" Pasteur pipet packed with silica gel, eluting with EtOAc. The resulting solution was concentrated to give the crude imidazole $\mathbf{2 7}$ as a brown oil, which was used directly in the next step.

The crude oil $27(2.00 \mathrm{~g})$ was dissolved in $\mathrm{MeOH}(20 \mathrm{~mL})$ in a $50 \mathrm{~mL}$ round bottom Schlenk flask. The flask was purged with $\mathrm{N}_{2} \times 3$, then $10 \% \mathrm{Pd} / \mathrm{C}(24.8 \mathrm{mg})$ was added. The flask was then fitted with a hydrogen balloon via a 3 way valve and it was evacuated and purged with hydrogen $\times 5$. The reaction was stirred under hydrogen for $16 \mathrm{~h}$, then the mixture was passed through a pad of Celite and concentrated to afford a yellow oil. The crude oil was is dissolved in DCM $(20 \mathrm{~mL})$ and transferred to a $20 \mathrm{~mL}$ vial, and $4 \mathrm{M} \mathrm{HCl}$ in dioxane $(291 \mu \mathrm{L}$, $1.16 \mathrm{mmol}$ ) was added and the reaction was stirred for $16 \mathrm{~h}$. The reaction was quenched by adding saturated $\mathrm{NaHCO}_{3}$ solution $(10 \mathrm{~mL})$, then the phases were separated and the aqueous phase was extracted with EtOAc $(10 \mathrm{~mL})$. The combined organics were dried over $\mathrm{Na}_{2} \mathrm{SO}_{4}$ and concentrated to give a brown oil, which was purified by flash chromatography $\left(\mathrm{SiO}_{2}, 10-20 \% \mathrm{MeOH} / \mathrm{DCM}\right)$ to give the title compound 28b (65 mg, $48 \%)$ over 4 steps. $R_{f}(10 \% \mathrm{MeOH}$ in DCM) 0.29 ; $[\mathrm{a}]_{\mathrm{D}}{ }^{20}-52\left(1.0, \mathrm{CH}_{2} \mathrm{Cl}_{2}\right)$; IR (thin film): $3407,1641,1251,1113$, $751 \mathrm{~cm}^{-1} ;{ }^{1} \mathrm{H}$ NMR $\left(300 \mathrm{MHz}, \mathrm{CDCl}_{3}\right) \delta=1.70(\mathrm{~s}, 2 \mathrm{H}), 2.91(\mathrm{dd}$, $J=13.7,8.7 \mathrm{~Hz}, 1 \mathrm{H}), 3.38(\mathrm{dd}, J=13.7,4.5 \mathrm{~Hz}, 1 \mathrm{H}), 4.37$ (dd, J=8.6, $4.5 \mathrm{~Hz}, 1 \mathrm{H}), 6.84(\mathrm{td}, J=7.5,1.3 \mathrm{~Hz}, 1 \mathrm{H}), 6.99(\mathrm{dd}, J=8.2,1.3 \mathrm{~Hz}$, $1 \mathrm{H}), 7.09-7.37(\mathrm{~m}, 7 \mathrm{H}), 7.46(\mathrm{dd}, J=7.7,1.7 \mathrm{~Hz}, 1 \mathrm{H}), 9.68(\mathrm{~s}, 1 \mathrm{H})$;

Tetrahedron, Vol 72, No. 27-28 (July 7, 2016): pg. 3905-3916. DOI. This article is C Elsevier and permission has been granted for this version to appear in e-Publications@Marquette. Elsevier does not grant permission for this article to be further copied/distributed or hosted elsewhere without the express permission from Elsevier. 
NOT THE PUBLISHED VERSION; this is the author's final, peer-reviewed manuscript. The published version may be accessed by following the link in the citation at the bottom of the page.

${ }^{13} \mathrm{C} \mathrm{NMR}\left(75 \mathrm{MHz} \mathrm{CDCl}_{3}\right) \delta=43.8,51.3,109.9,117.4,117.4,119.3$, $124.8,127.1,128.4,128.9,129.6,137.5,140.7,149.2,156.0$; HRMS $\left(\mathrm{ESI}^{+}\right.$) calcd for $\mathrm{C}_{17} \mathrm{H}_{17} \mathrm{~N}_{3} \mathrm{O}[\mathrm{M}+\mathrm{H}] 280.1444$, found 280.1440 .

\subsection{Crystallographic data}

CCDC 1463770 contains the supplementary crystallographic data for Fig. 2 in this paper. These data can be obtained free of charge from The Cambridge Crystallographic Data Centre via www.ccdc.cam.ac.uk/data request/cif.

\section{Acknowledgements}

We thank Rajdeep Virdi for the synthesis of several intermediates, Dr. Sheng Cai for assistance with LC-MS and NMR instruments, Shimadzu Inc. for a grant to support the purchase of the LC-MS used in these studies, Marquette University for startup funding, and the American Chemical Society Petroleum Research Fund (grant number 55732-DNI1) for support of our research program.

\section{References and notes}

1P.J. Walsh, M.C. Kozlowski. Fundamentals of Asymmetric Catalysis. University Science Books (2009)

${ }^{2}$ D.H. Paull, C.J. Abraham, M.T. Scerba, E. Alden-Danforth, T. Lectka. Acc. Chem. Res., 41 (2008), pp. 655-663

3 L. Stegbauer, F. Sladojevich, D.J. Dixon. Chem. Sci., 3 (2012), pp. 942-958

${ }^{4}$ A.E. Allen, D.W.C. MacMillan. Chem. Sci., 3 (2012), p. 633

5Z. Du, Z. Shao. Chem. Soc. Rev., 42 (2013), p. 1337

6T.D. Machajewski, C.-H. Wong. Angew. Chem., Int. Ed., 39 (2000), pp. 1352-1375

7YY. Ito, M. Sawamura, T. Hayashi. J. Am. Chem. Soc., 108 (1986), pp. 64056406

8Y. Hamashima, D. Sawada, M. Kanai, M. Shibasaki. J. Am. Chem. Soc., 121 (1999), pp. 2641-2642

9 S. France, M.H. Shah, A. Weatherwax, H. Wack, J.P. Roth, T. Lectka. J. Am. Chem. Soc., 127 (2005), pp. 1206-1215

10 R. Mahrwald. Drug Discov. Today Technol., 10 (2013), pp. e29-e36

115. Krautwald, D. Sarlah, M.A. Schafroth, E.M. Carreira. Science, 340 (2013), pp. $1065-1068$

12B.M. Trost, C.S. Brindle. Chem. Soc. Rev., 39 (2010), p. 1600

$\underline{13}$ V. Bisai, A. Bisai, V.K. Singh. Tetrahedron, 68 (2012), pp. 4541-4580

Tetrahedron, Vol 72, No. 27-28 (July 7, 2016): pg. 3905-3916. DOI. This article is @ Elsevier and permission has been granted for this version to appear in e-Publications@Marquette. Elsevier does not grant permission for this article to be further copied/distributed or hosted elsewhere without the express permission from Elsevier. 
NOT THE PUBLISHED VERSION; this is the author's final, peer-reviewed manuscript. The published version may be accessed by following the link in the citation at the bottom of the page.

${ }^{14}$ T. Kano, Y. Yamaguchi, Y. Tanaka, K. Maruoka. Angew. Chem., Int. Ed., 46 (2007), pp. 1738-1740

15S. Luo, H. Xu, J. Li, L. Zhang, J.-P. Cheng. J. Am. Chem. Soc., 129 (2007), pp. 3074-3075

16X.-Y. Xu, Y.-Z. Wang, L.-Z. Gong. Org. Lett., 9 (2007), pp. 4247-4249

17]. Li, N. Fu, X. Li, S. Luo, J.-P. Cheng. J. Org. Chem., 75 (2010), pp. 45014507

${ }^{18}$ A.B. Northrup, D.W.C. MacMillan. J. Am. Chem. Soc., 124 (2002), pp. 67986799

19 M. Nakagawa, H. Nako, K.-I. Watanabe. Chem. Lett. (1985), pp. 391-394

20T. Darbre, M. Machuqueiro. Chem. Comm. (2003), pp. 1090-1091

21]. Paradowska, M. Stodulski, J. Mlynarski. Adv. Synth. Catal., 349 (2007), pp. 1041-1046

22-S. Itoh, M. Kitamura, Y. Yamada, S. Aoki. Chem.-Eur. J., 15 (2009), pp. 10570-10584

23Z. Xu, P. Daka, H. Wang. Chem. Comm. (2009), p. 6825

24Z. Xu, P. Daka, I. Budik, H. Wang, F.-Q. Bai, H.-X. Zhang. Eur. J. Org. Chem., 2009 (2009), pp. 4581-4585

25 P. Daka, Z. Xu, A. Alexa, H. Wang. Chem. Comm. (2011), pp. 224-226

26A. Karmakar, T. Maji, S. Wittmann, O. Reiser. Chem.-Eur. J., 17 (2011), pp. 11024-11029

27$U$. Scheffler, R. Mahrwald. Synlett (2011), pp. 1660-1667

28p. Wipf, S. Venkatraman. J. Org. Chem., 61 (1996), pp. 6517-6522

${ }^{29}$ A.J. Phillips, Y. Uto, P. Wipf, M.J. Reno, D.R. Williams. Org. Lett., 2 (2000), pp. $1165-1168$

30I. Thomsen, U. Pedersen, P.B. Rasmussen, B. Yde, T.P. Andersen, S.O. Lawesson. Chem. Lett. (1983), pp. 809-810

31D. Wiedenhoeft, A.R. Benoit, J.D. Porter, Y. Wu, R.S. Virdi, A. Shanaa, C. Dockendorff. Synthesis (2016) http://dx.doi.org/10.1055/s-00351560436 in press

32I. Pravst, M. Zupan, S. Stavber. Tetrahedron, 64 (2008), pp. 5191-5199

${ }^{33}$ A. Mori, T. Mizusaki, Y. Miyakawa, E. Ohashi, T. Haga, T. Maegawa, Y. Monguchi, H. Sajiki. Tetrahedron, 62 (2006), pp. 11925-11932

345. Kobayashi, K. Manabe. Acc. Chem. Res., 35 (2002), pp. 209-217

\section{Supplementary data}

Tetrahedron, Vol 72, No. 27-28 (July 7, 2016): pg. 3905-3916. DOI. This article is @ Elsevier and permission has been granted for this version to appear in e-Publications@Marquette. Elsevier does not grant permission for this article to be further copied/distributed or hosted elsewhere without the express permission from Elsevier. 


\section{Supplementary Material}

\section{Multifunctional heterocyclic scaffolds for hybrid Lewis acid/Lewis base catalysis of carbon-carbon bond formation}

Dennis Wiedenhoeft, Adam R. Benoit, Yibiao Wu, Jacob D. Porter, Elisia Meyle, Teresa H. W. Yeung, Raechel Huff, Sergey V. Lindeman, and Chris Dockendorff

Department of Chemistry, Marquette University, P.O. Box 1881, Milwaukee, WI, 53201-1881, USA

E-mail: christopher.dockendorff@mu.edu

\section{Contents}

1. Author contributions

2. General reaction screening protocol

3. Synthetic protocols for the preparation of precatalysts 29 and $\mathbf{3 0}$

4. MS study of $18 \mathbf{c}-\mathrm{Zn}(\mathrm{OTf})_{2}$

5. NMR spectra

\section{Author contributions}

Dennis Wiedenhoeft: Assisted with catalyst design; designed experiments; designed, investigated, and optimized precatalyst synthetic routes; synthesized and characterized precatalysts and aldol products; developed HPLC methods; screened reactions; analyzed data; wrote supporting information; supervised research; grew single crystals for x-ray analysis.

Adam Benoit: Assisted with catalyst design; designed, investigated, and optimized precatalyst syntheses; characterized products; developed HPLC methods; screened reactions; analyzed data; designed experiments; wrote supporting information; edited the manuscript; supervised research.

Yibiao Wu: Synthesized and characterized precatalysts and aldol products; screened reactions.

Jacob Porter: Synthesized and characterized precatalysts; performed NMR and MS studies.

Elisia Meyle: Synthesized and characterized precatalysts.

Teresa Yeung: Synthesized precatalyst intermediates.

Raechel Huff: Synthesized precatalyst intermediates. 
Sergey Lindeman: Determined x-ray structure.

Chris Dockendorff: Designed catalysts; designed synthetic routes; analyzed data; designed experiments; wrote and edited the manuscript and supporting information; supervised research.

\section{General reaction screening protocol}
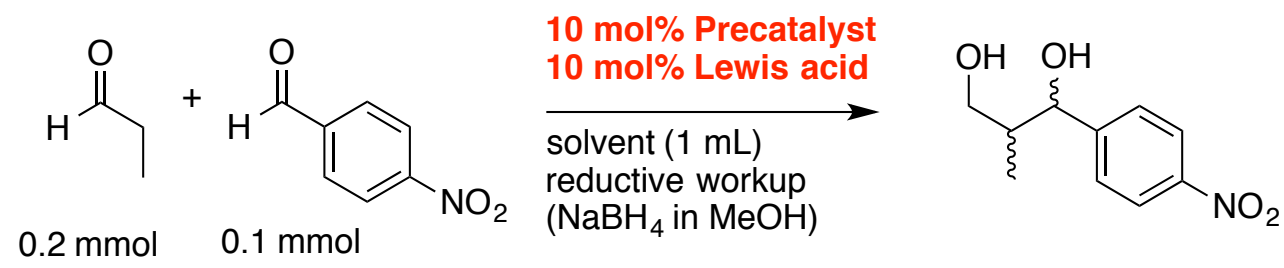

Stock solutions of precatalyst $(0.02 \mathrm{M})$, benzaldehyde acceptor $(0.40 \mathrm{M})$, and aldehyde or ketone donor $(0.80 \mathrm{M})$ were prepared. All precatalysts were used as free bases (or zwitterions) by neutralizing $\mathrm{HCl}$ salts with aqueous ammonium hydroxide and extracting with DCM prior to use.

1) Metal salts $(0.01 \mathrm{mmol})$ were weighed into separate $1.5 \mathrm{~mL}$ HPLC vials.

2) If solid additives were included, they were added to the vials at this time.

3) Precatalyst solutions (500 $\mu \mathrm{L}$ of $0.02 \mathrm{M}$ stock solution, $0.01 \mathrm{mmol}$ ) were added to each vial.

4) If additive solutions were included, they were added to the vials next.

5) Aldehyde acceptor solution ( $250 \mu \mathrm{L}$ of $0.40 \mathrm{M}$ solution, $0.1 \mathrm{mmol}$ ), was added to each vial.

6) Aldehyde or ketone donor ( $250 \mu \mathrm{L}$ of $0.80 \mathrm{M}$ solution, $0.2 \mathrm{mmol}$ ) was added to each vial.

After addition of all reagents, the vials were capped (PTFE septa) and placed in a cardboard vial box attached to a vortex shaker. Vials were shaken for 24 hours on the lowest speed to avoid leakage from the vials. $9 \mathrm{~mL}$ glass test tubes were labeled to correspond to each of the reaction vials and sodium borohydride ( $\sim 75 \mathrm{mg}, 2 \mathrm{mmol}, 20$ eq.) was added to each tube and cooled on ice. 4:1 DCM:MeOH $(1 \mathrm{~mL})$ was added, then the reaction solutions were pipeted dropwise (over $\sim 30 \mathrm{~s}$ ) to the test tubes. The tubes were removed the ice bath and warmed to room temperature over thirty minutes, with periodic mixing. Saturated aqueous ammonium chloride solution (1 $\mathrm{mL}$ ) was then added via pipet dropwise $(\sim 1 \mathrm{~min}$.) to each tube to quench the reduction reaction, followed by $1 \mathrm{M}$ aqueous $\mathrm{HCl}(1 \mathrm{~mL})$ added via pipet dropwise $(\sim 1 \mathrm{~min}$.) to further neutralize the solutions and to help dissolve solid precipitates. DCM $(\sim 1 \mathrm{~mL})$ was added to each tube to resolve the phases. The organic phases were separated to fresh $9 \mathrm{~mL}$ tubes, then the remaining solutions were extracted with additional DCM $(2 \times 2 \mathrm{~mL})$. The combined organic solutions were concentrated via Speedvac (initially at 400 torr with low heating, then 25 torr). A stock solution 
of LC-MS grade isopropanol with $5 \mathrm{mg} / \mathrm{mL}$ of $o$-dichlorobenzene as an internal standard was made. Each crude sample was dissolved in $1 \mathrm{~mL}$ of this stock solution and filtered through a 0.22 micron nylon syringe filter into a $1.5 \mathrm{~mL}$ HPLC vial. The samples were analyzed by HPLC using $5 \mathrm{uL}$ injections and 13:87 IPA:hexane isocratic method $(1 \mathrm{~mL} / \mathrm{min}$.) for $20 \mathrm{~min}$., with a Phenomenex Lux $5 \mu \mathrm{m}$ Cellulose-2 column $(250 \times 4.6 \mathrm{~mm})$ and UV detection at $\lambda=254 \mathrm{~nm}$. Representative retention times: $3.3 \mathrm{~min}$ : $o$-dichlorobenzene; $9.3 \mathrm{~min}$ : benzyl alcohol; $10.7 \mathrm{~min}$., syn enantiomer 1; 12.0 min., syn enantiomer 2; 14.5 min., anti enantiomer 1; 15.6 min., anti enantiomer 2 .

\section{Synthetic protocols for the preparation of precatalysts 29 and $\mathbf{3 0}$}

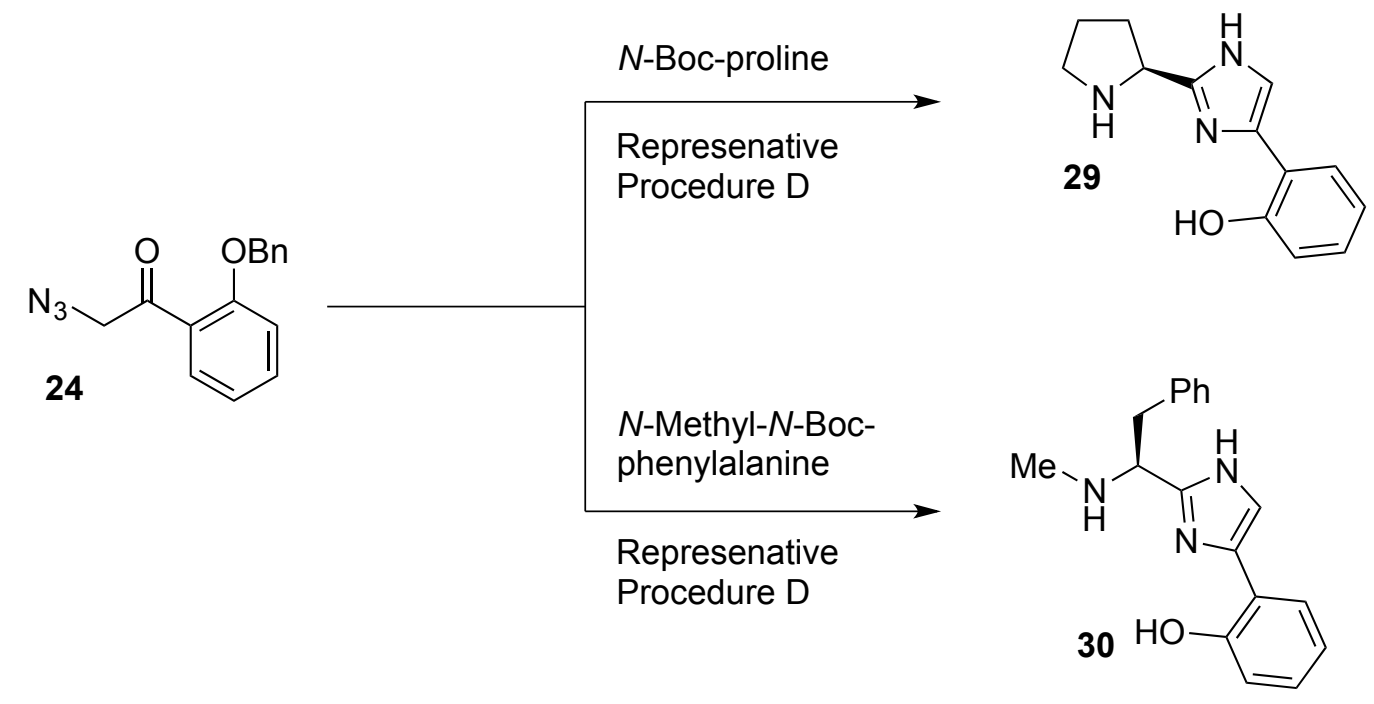

(S)-2-(2-(pyrrolidin-2-yl)-1H-imidazol-4-yl)phenol (29b)

The compound was made following Representative Procedure D (see main manuscript) using $N$-Boc-L-proline as starting material: beige solid, $\mathrm{R}_{\mathrm{f}}(10 \% \mathrm{MeOH}$ in $\mathrm{DCM}) 0.21$; [a] ${ }_{\mathrm{D}}{ }^{20}-123$ (1.0, $\mathrm{CH}_{2} \mathrm{Cl}_{2}$ ); IR (thin film): 2870, 1578, 1476, 1398, 1252, $756 \mathrm{~cm}^{-1} ;{ }^{1} \mathrm{H}$ NMR $(300 \mathrm{MHz}$, $\left.\mathrm{CDCl}_{3}\right) \delta=1.7-1.9(\mathrm{~m}, 2 \mathrm{H}), 1.98-2.32(\mathrm{~m}, 2 \mathrm{H}), 2.83-3.15(\mathrm{~m}, 2 \mathrm{H}), 4.41(\mathrm{dd}, J=8.0,5.5 \mathrm{~Hz}$, $1 \mathrm{H}), 6.73-6.87(\mathrm{~m}, 1 \mathrm{H}), 6.88-7.01(\mathrm{~m}, 1 \mathrm{H}), 7.06-7.17(\mathrm{~m}, 1 \mathrm{H}), 7.19(\mathrm{~d}, J=0.5 \mathrm{~Hz}, 1 \mathrm{H}), 7.35-$ $7.5(\mathrm{~m}, 1 \mathrm{H}) ;{ }^{13} \mathrm{C} \mathrm{NMR}\left(75 \mathrm{MHz}, \mathrm{CDCl}_{3}\right) \delta=25.9,28.7,32.1,47.0,55.8,109.8,117.4,119.2$, 124.7, 124.7, 128.3, 141.0, 149.3, 156.0; HRMS $\left(\mathrm{ESI}^{+}\right)$calculated for $\mathrm{C}_{13} \mathrm{H}_{15} \mathrm{~N}_{3} \mathrm{O}[\mathrm{M}+\mathrm{H}]$ 230.1288 , found 230.1281 .

\section{(S)-2-(2-(1-(methylamino)-2-phenylethyl)-1H-imidazol-4-yl)phenol (30)}

The compound was made following Representative Procedure D (see main manuscript) using $N$-methyl- $N$-Boc-L-phenylalanine as starting material: yellow solid, $\mathrm{R}_{\mathrm{f}}(10 \% \mathrm{MeOH}$ in DCM) 0.42 ; [a $]_{\mathrm{D}}{ }^{20}-7\left(1.0, \mathrm{CH}_{2} \mathrm{Cl}_{2}\right.$ ); IR (thin film): $3118,1585,1479,1412,1244,1126,735 \mathrm{~cm}^{-1} ;{ }^{1} \mathrm{H}$ NMR $\left(400 \mathrm{MHz}, \mathrm{CDCl}_{3}\right) \delta=2.33(\mathrm{t}, J=1.5 \mathrm{~Hz}, 3 \mathrm{H}), 2.97$ (dd, $\left.J=13.9,8.4 \mathrm{~Hz}, 1 \mathrm{H}\right), 3.23(\mathrm{dd}$, $J=13.9,4.8 \mathrm{~Hz}, 1 \mathrm{H}), 3.88-4.22(\mathrm{~m}, 1 \mathrm{H}), 6.84(\mathrm{td}, J=7.5,1.7 \mathrm{~Hz}, 1 \mathrm{H}), 6.99(\mathrm{dd}, J=8.4,1.8$ 
$\mathrm{Hz}, 1 \mathrm{H}), 7.14(\mathrm{~d}, J=7.1 \mathrm{~Hz}, 3 \mathrm{H}), 7.2-7.38(\mathrm{~m}, 5 \mathrm{H}), 7.46(\mathrm{dd}, J=7.9,1.8 \mathrm{~Hz}, 1 \mathrm{H}), 9.53(\mathrm{~s}, 1 \mathrm{H})$; ${ }^{13} \mathrm{C}$ NMR $\left(75 \mathrm{MHz}, \mathrm{CDCl}_{3}\right) \delta=34.8,41.5,60.1,110.0,117.3,117.5,119.2,124.7,127.2,128.4$, $129.0,129.4,137.3,140.9,148.2,156.1$; HRMS $\left(\mathrm{ESI}^{+}\right)$calculated for $\mathrm{C}_{18} \mathrm{H}_{19} \mathrm{~N}_{3} \mathrm{O}[\mathrm{M}+\mathrm{H}]$ 294.1601, found 294.1605.

\section{MS study of $18 \mathrm{c}-\mathrm{Zn}(\mathrm{OTf})_{2}$}

$\mathrm{Zn}(\mathrm{OTf})_{2}(2.0 \mathrm{mg}, 0.006 \mathrm{mmol})$ and $18 \mathrm{c}(0.006 \mathrm{mmol})$ were added to a $4.0 \mathrm{~mL}$ vial then dissolved in $\mathrm{CH}_{3} \mathrm{CN}(1.0 \mathrm{~mL})$. The solids were dissolved and the mixtures sat for $1 \mathrm{~h}$ before being analyzed by mass spectrometry. Samples were made by adding an aliquot of ligand-metal mixture to LC-MS grade methanol (approximately $1 \mathrm{~mL}$ ). The samples were directly injected into the mass spectrometer (Shimadzu 2020 single quadrupole) using methanol as the mobile phase. The mass range analyzed was $100-1300 \mathrm{~m} / \mathrm{z}$ and the interface voltage was set to $4.5 \mathrm{kV}$. Dual ESI and APCI ionization modes were used (positive mode).
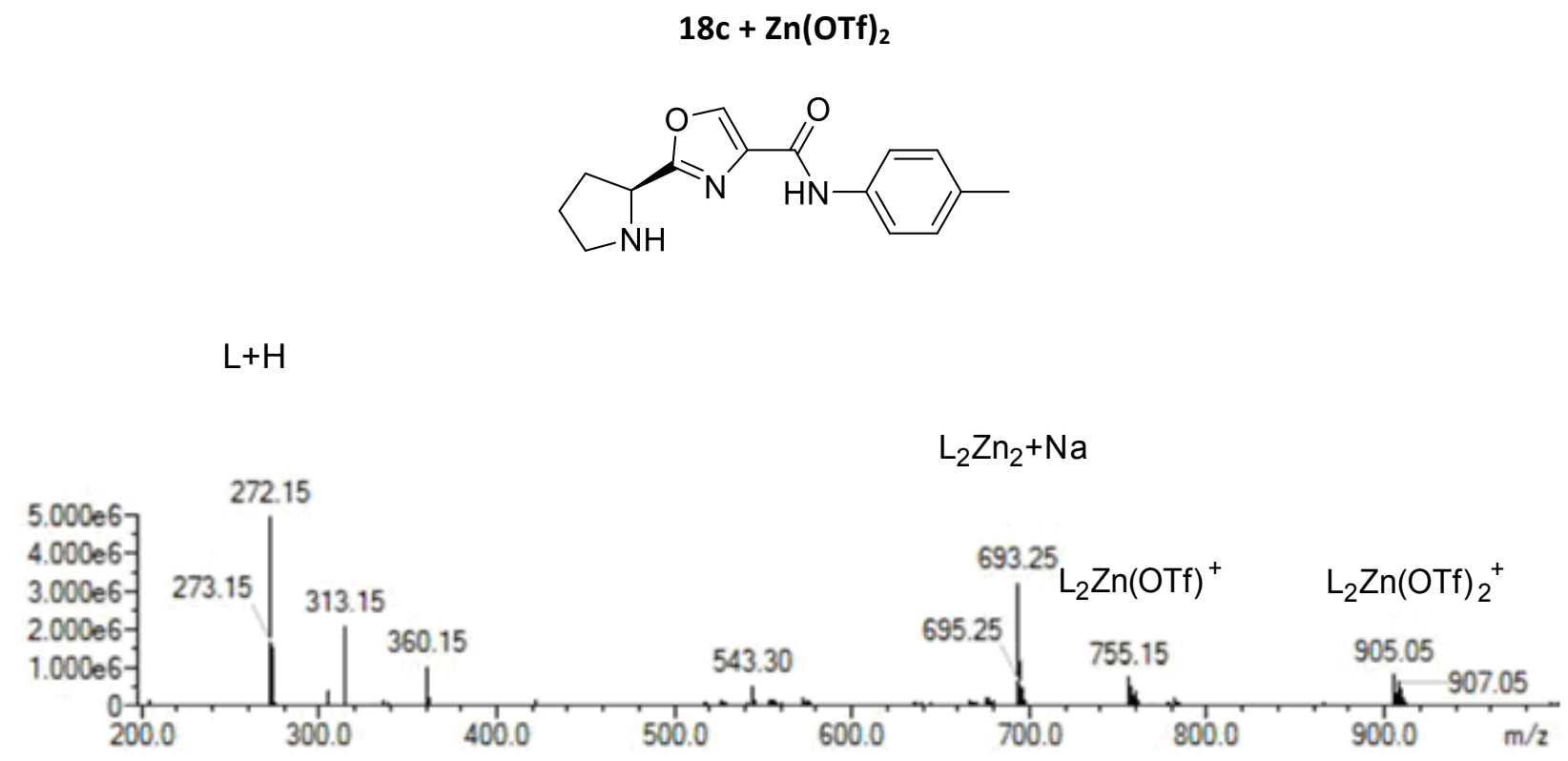


\section{NMR spectra}
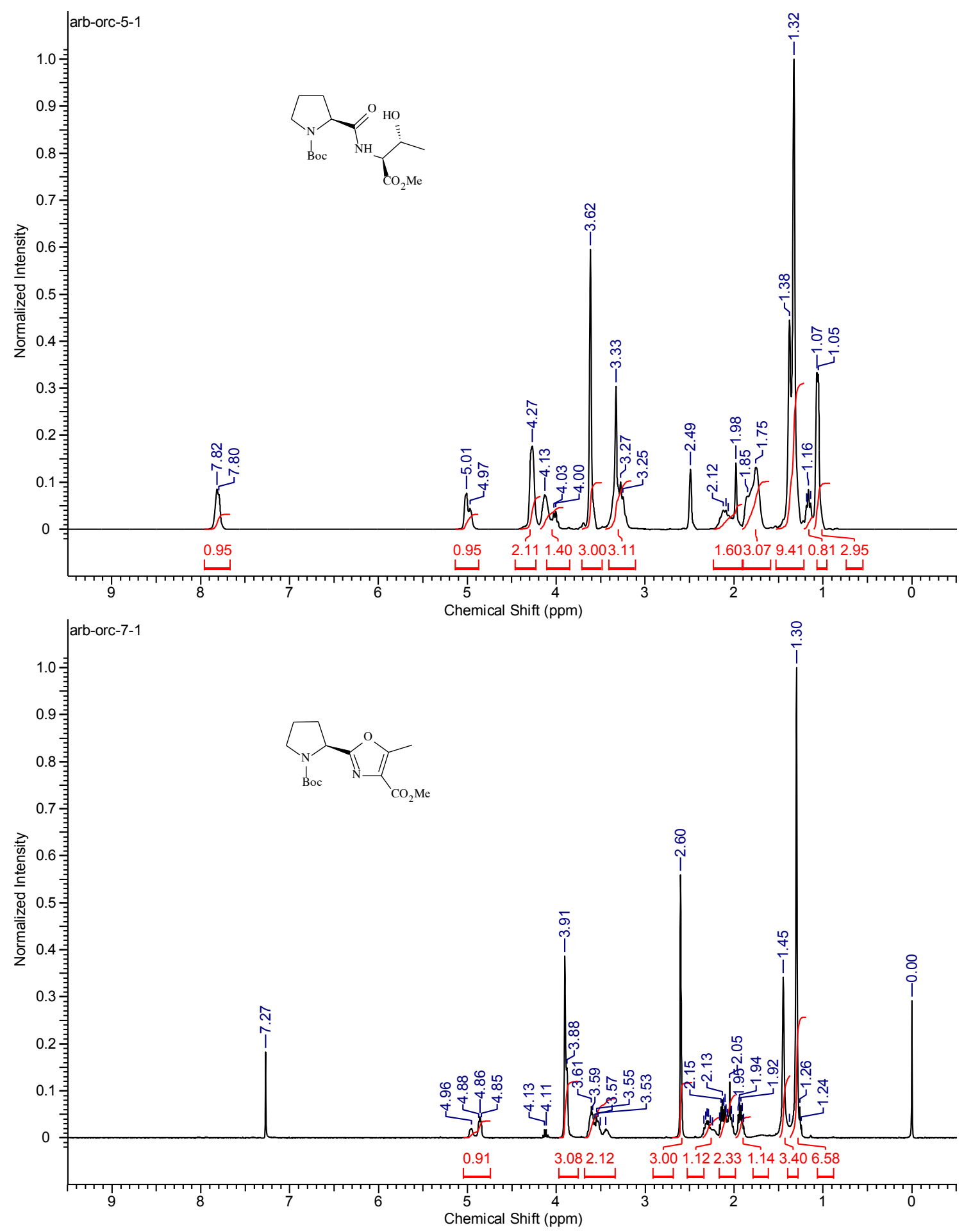

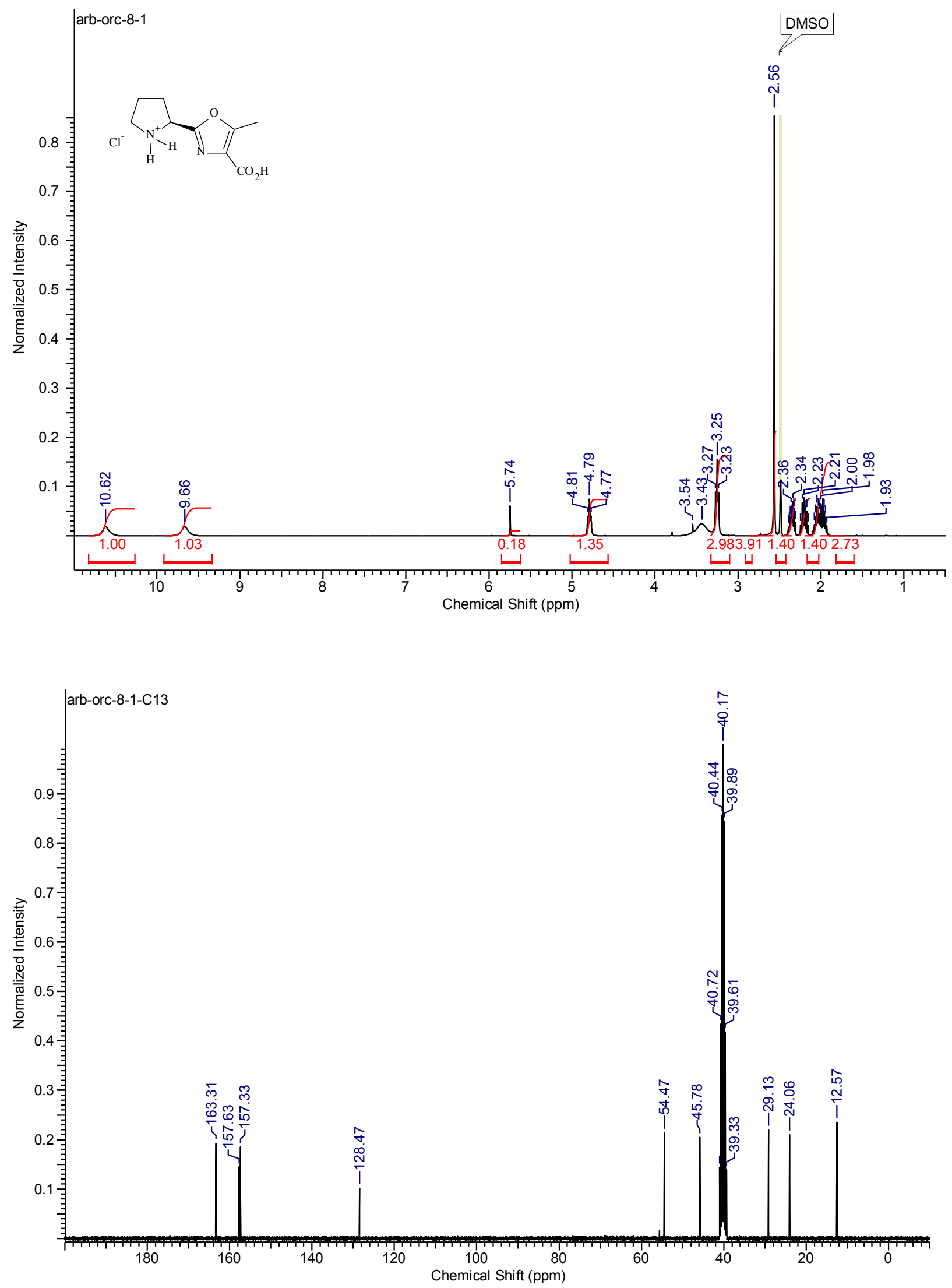

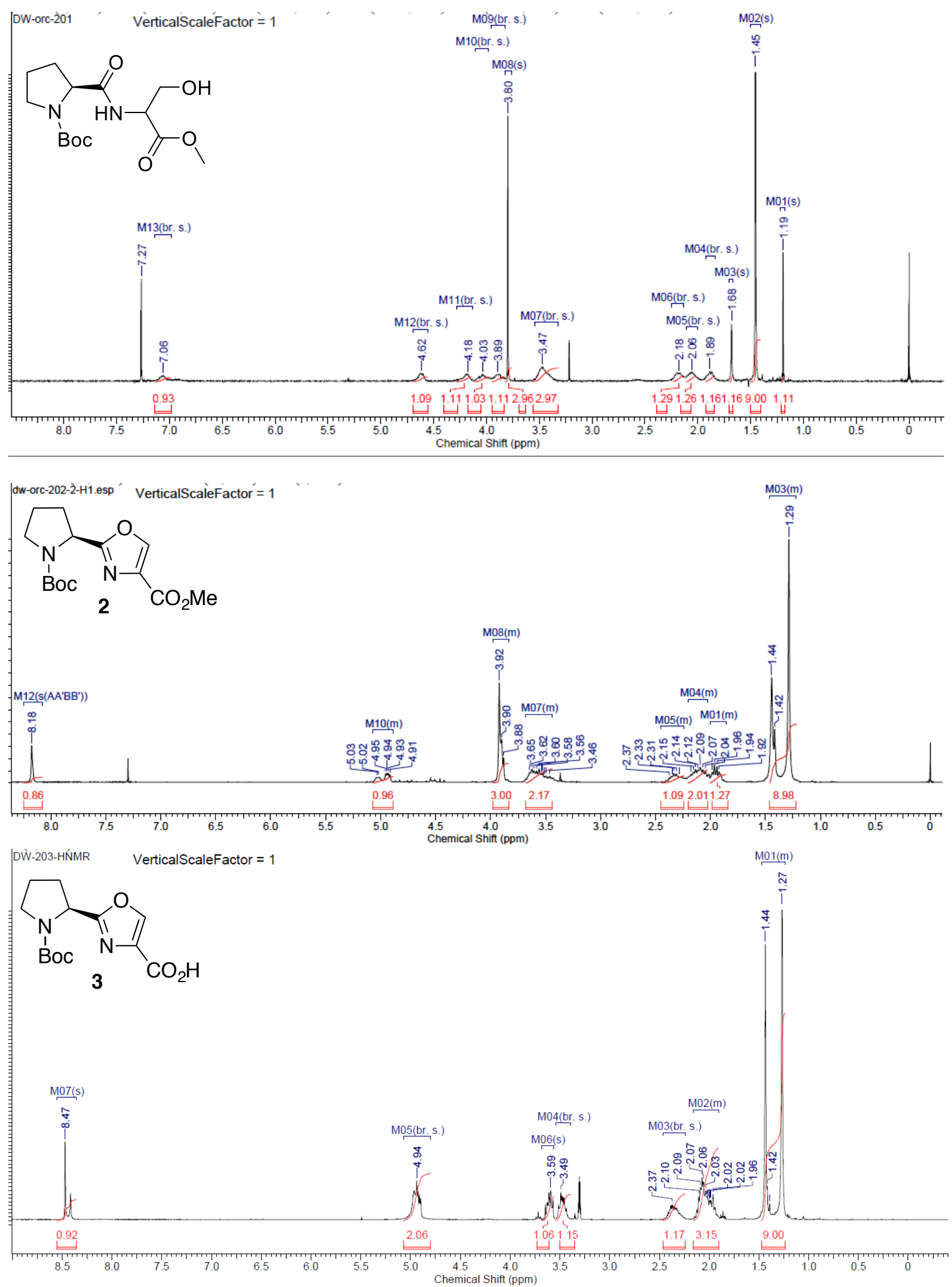


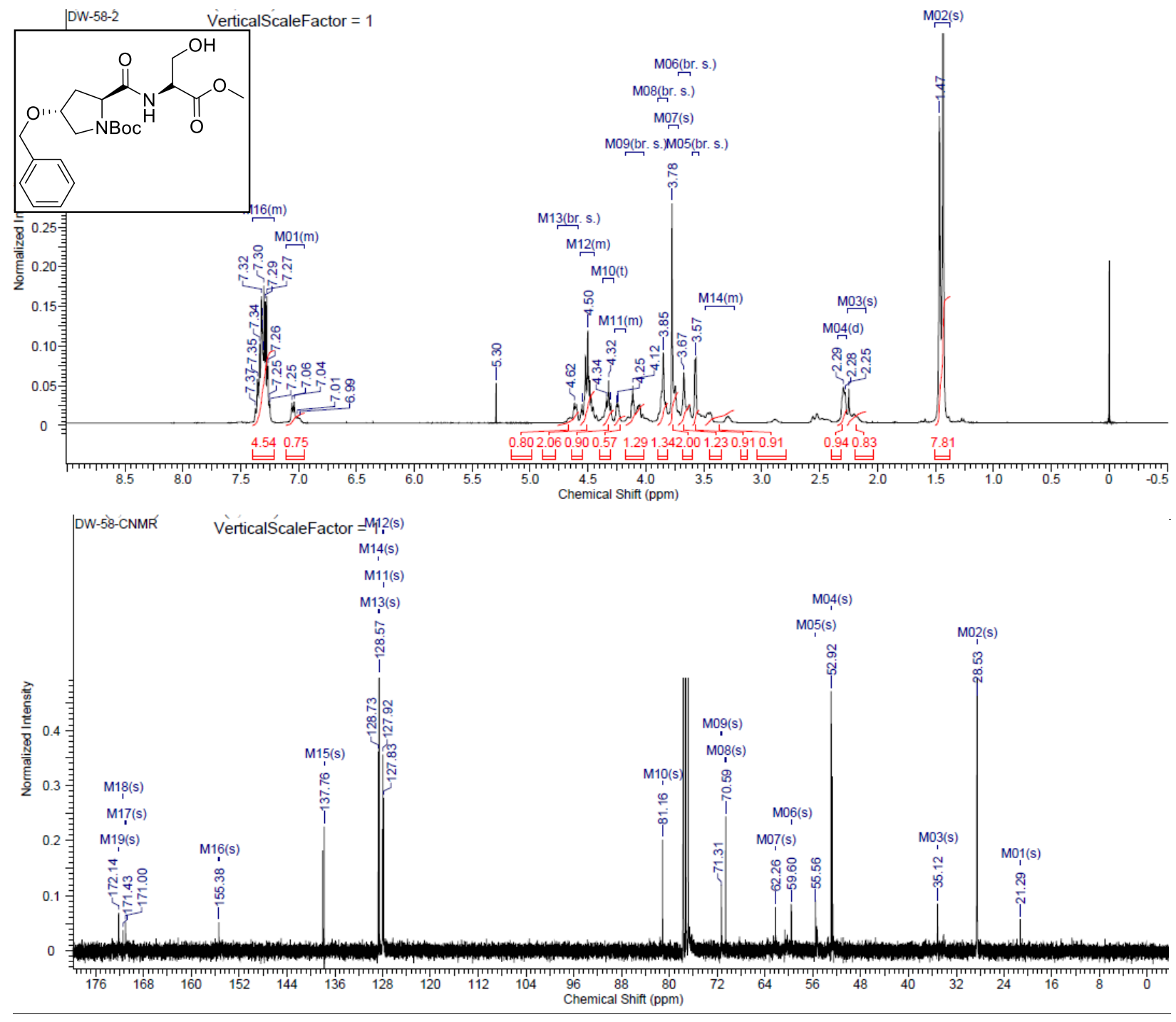



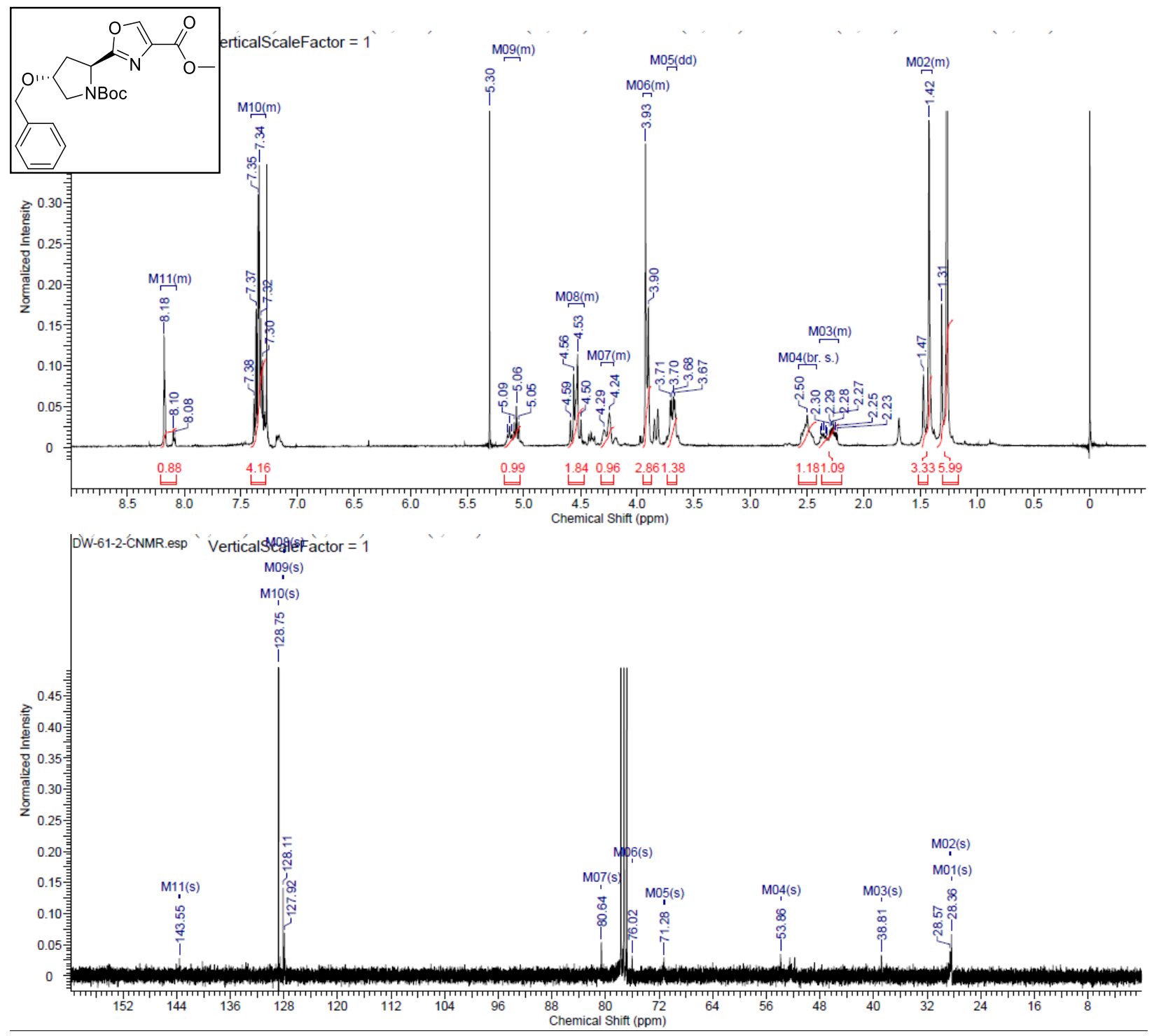


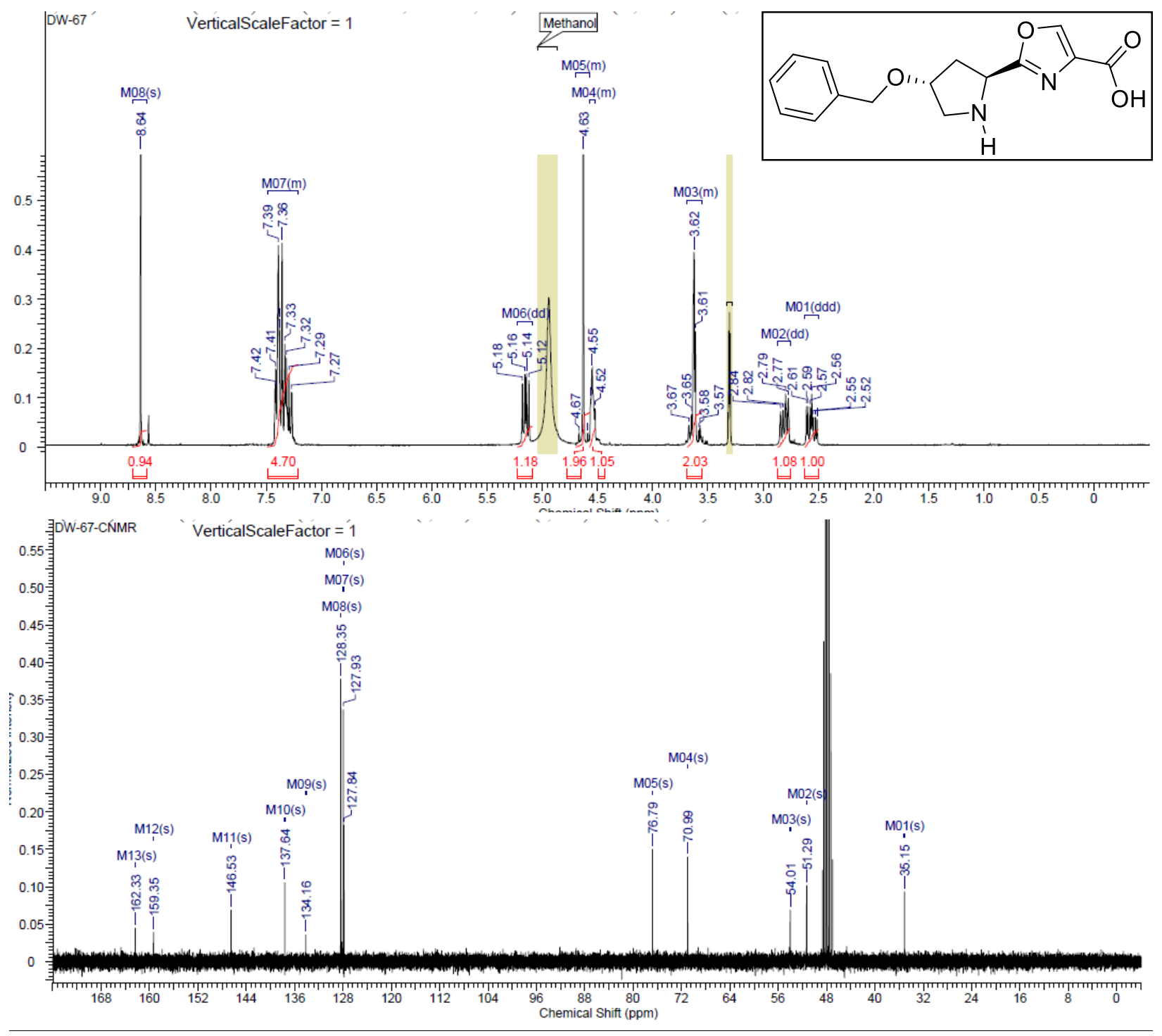



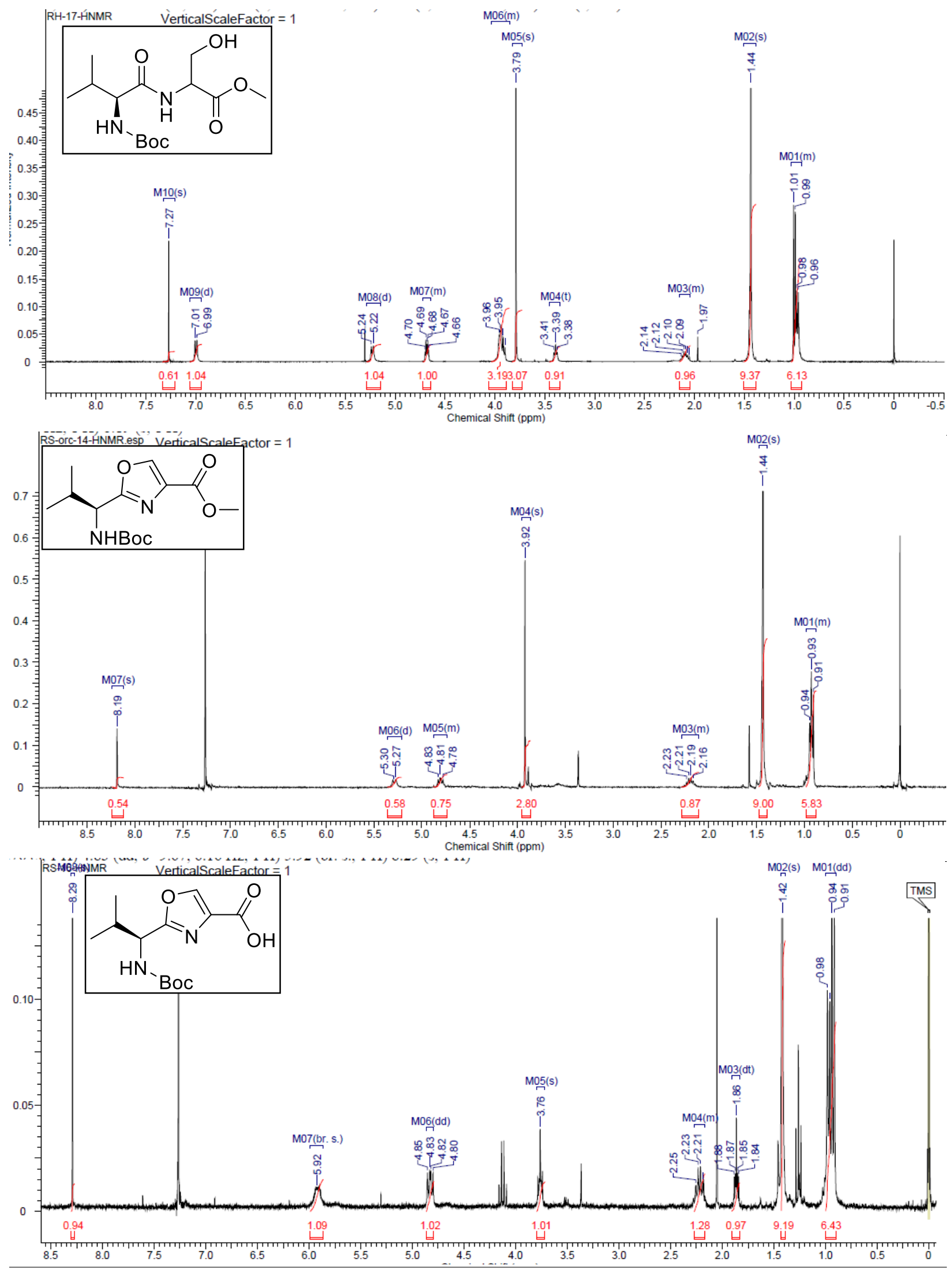

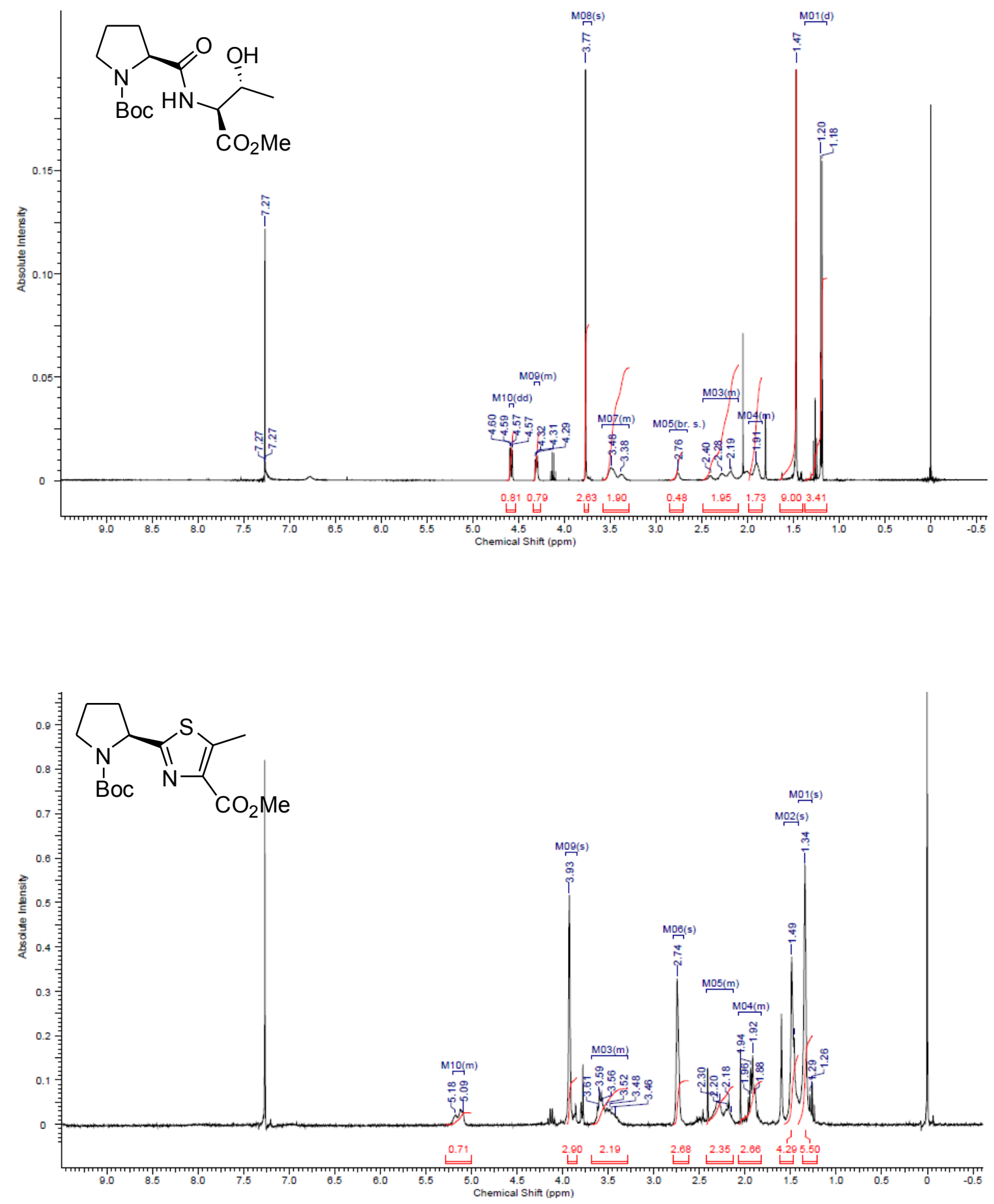

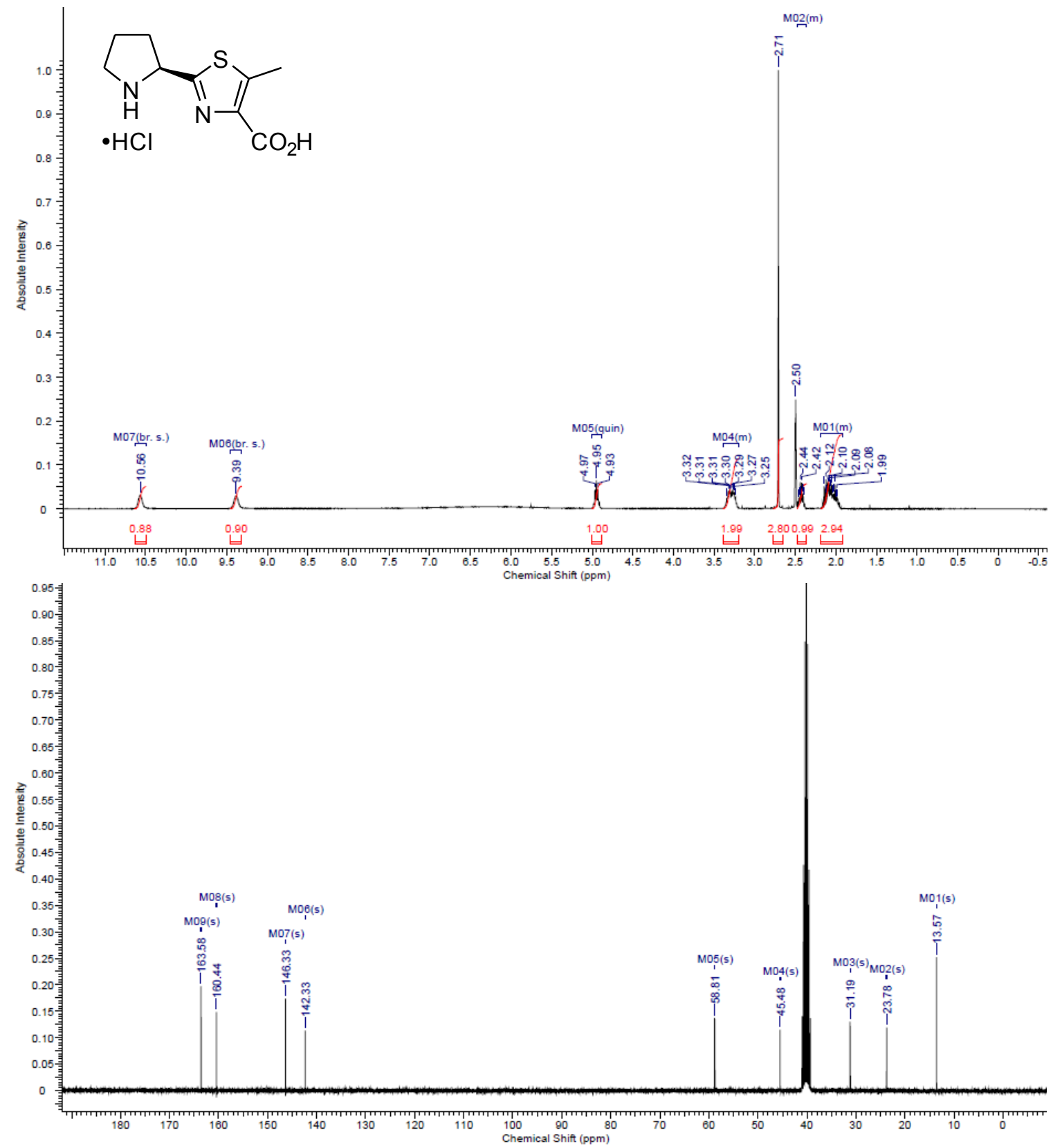

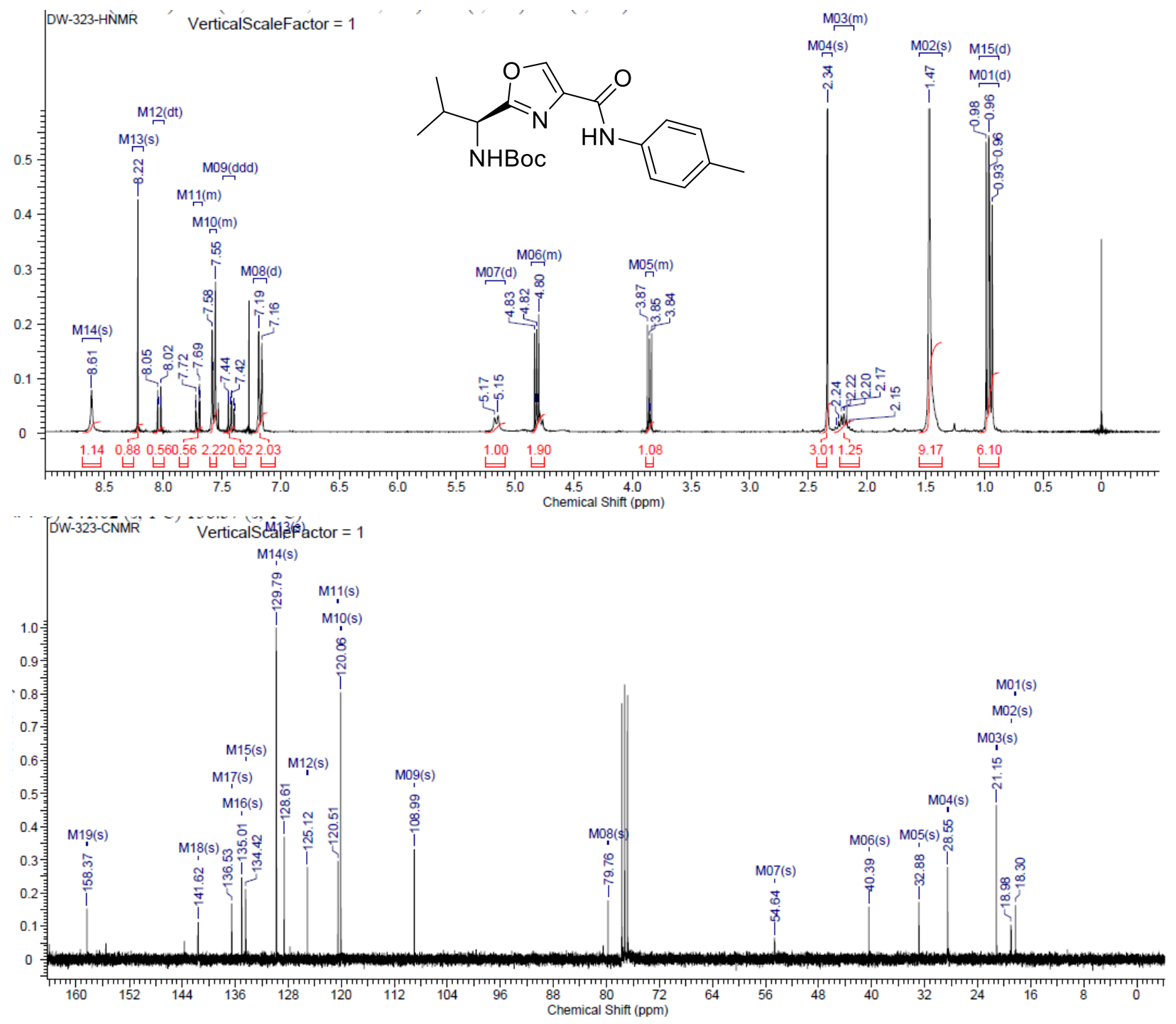

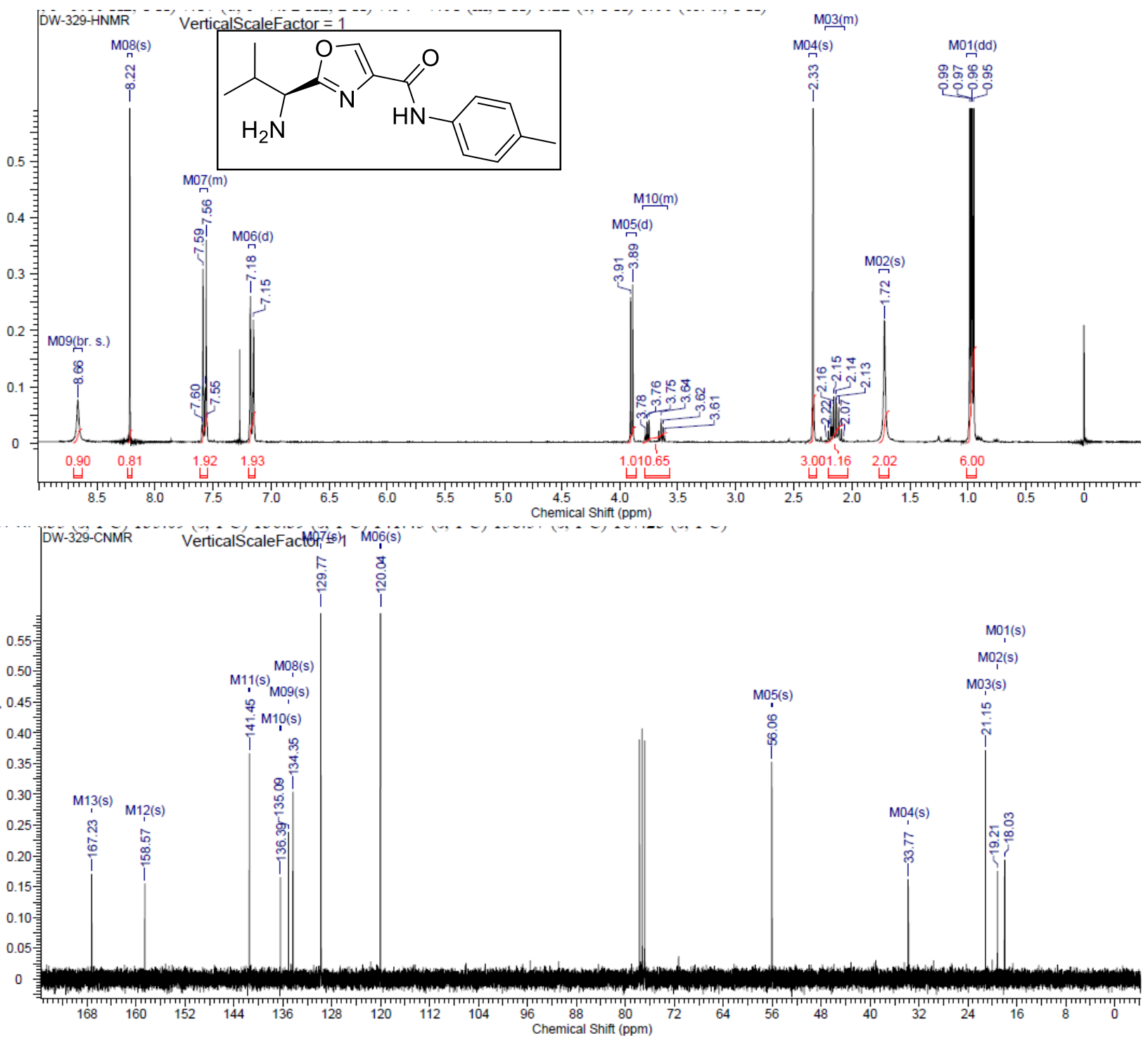


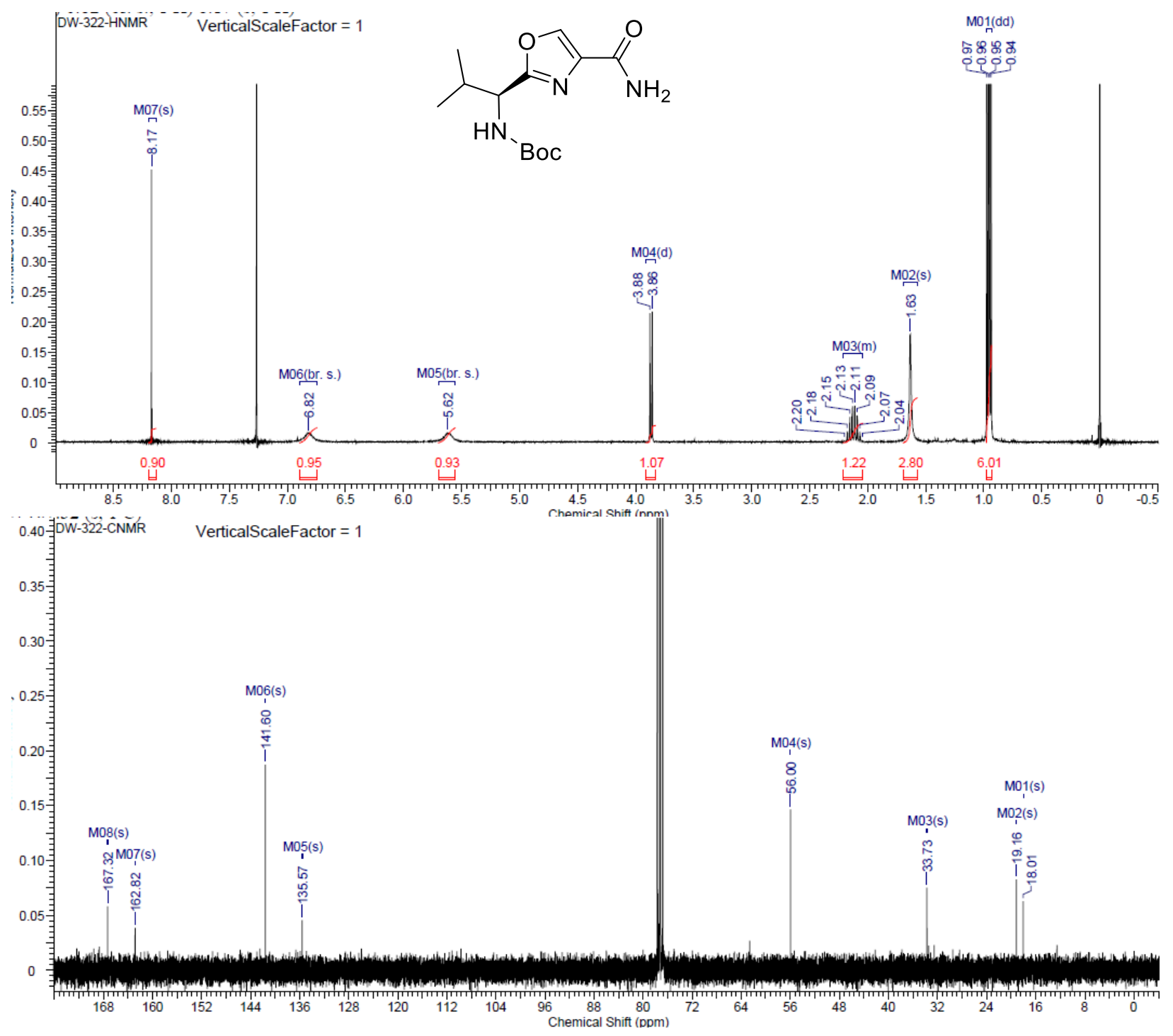



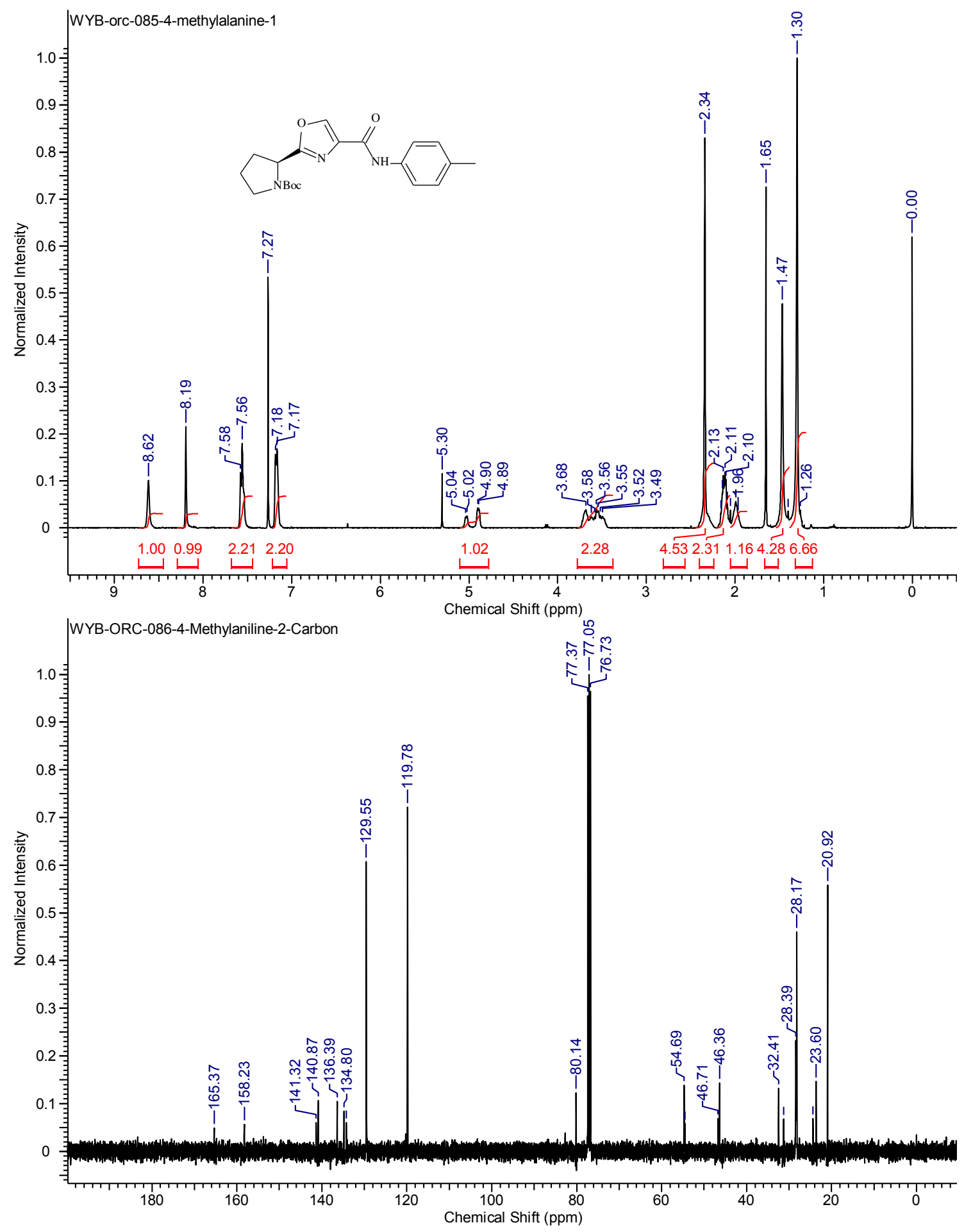

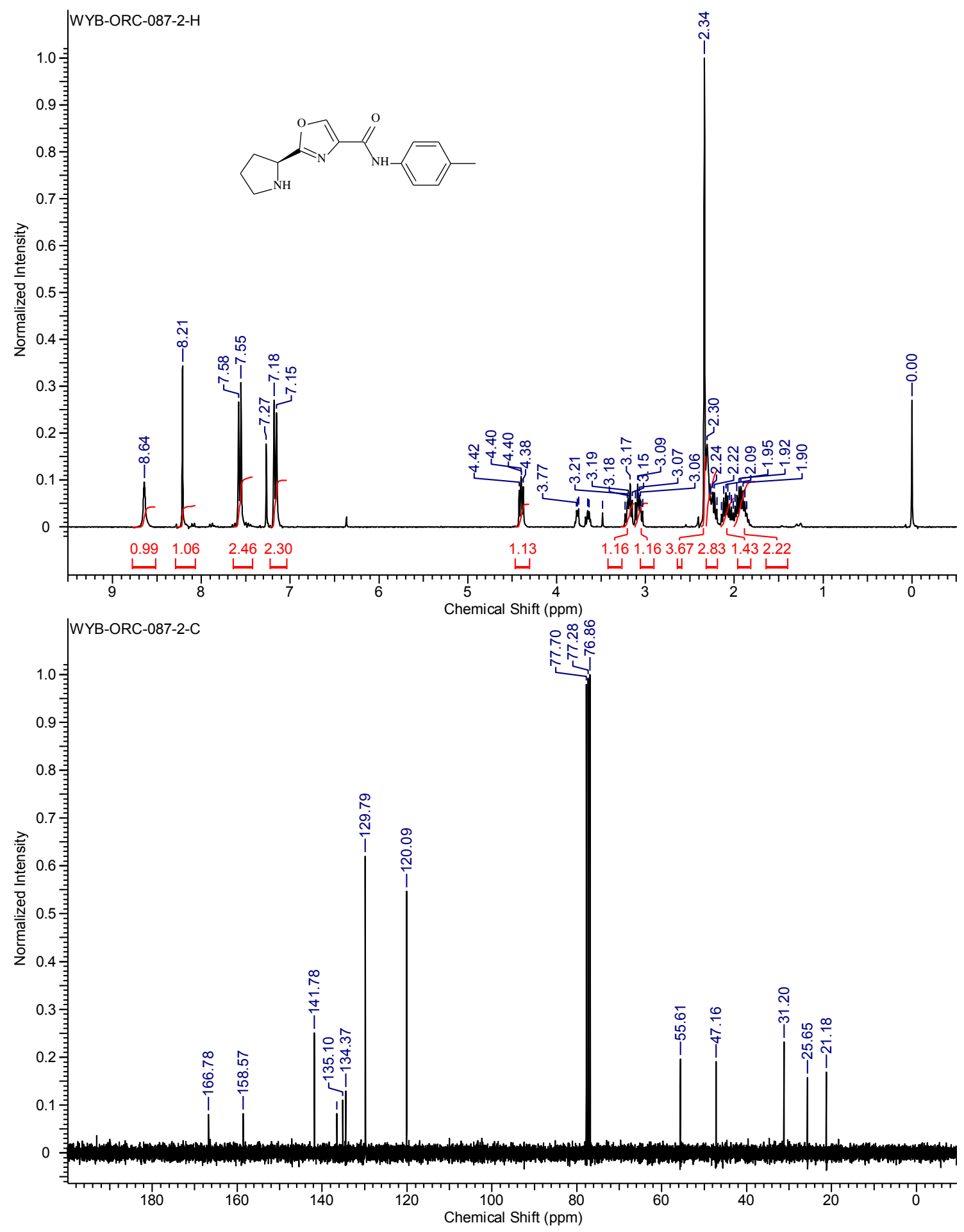

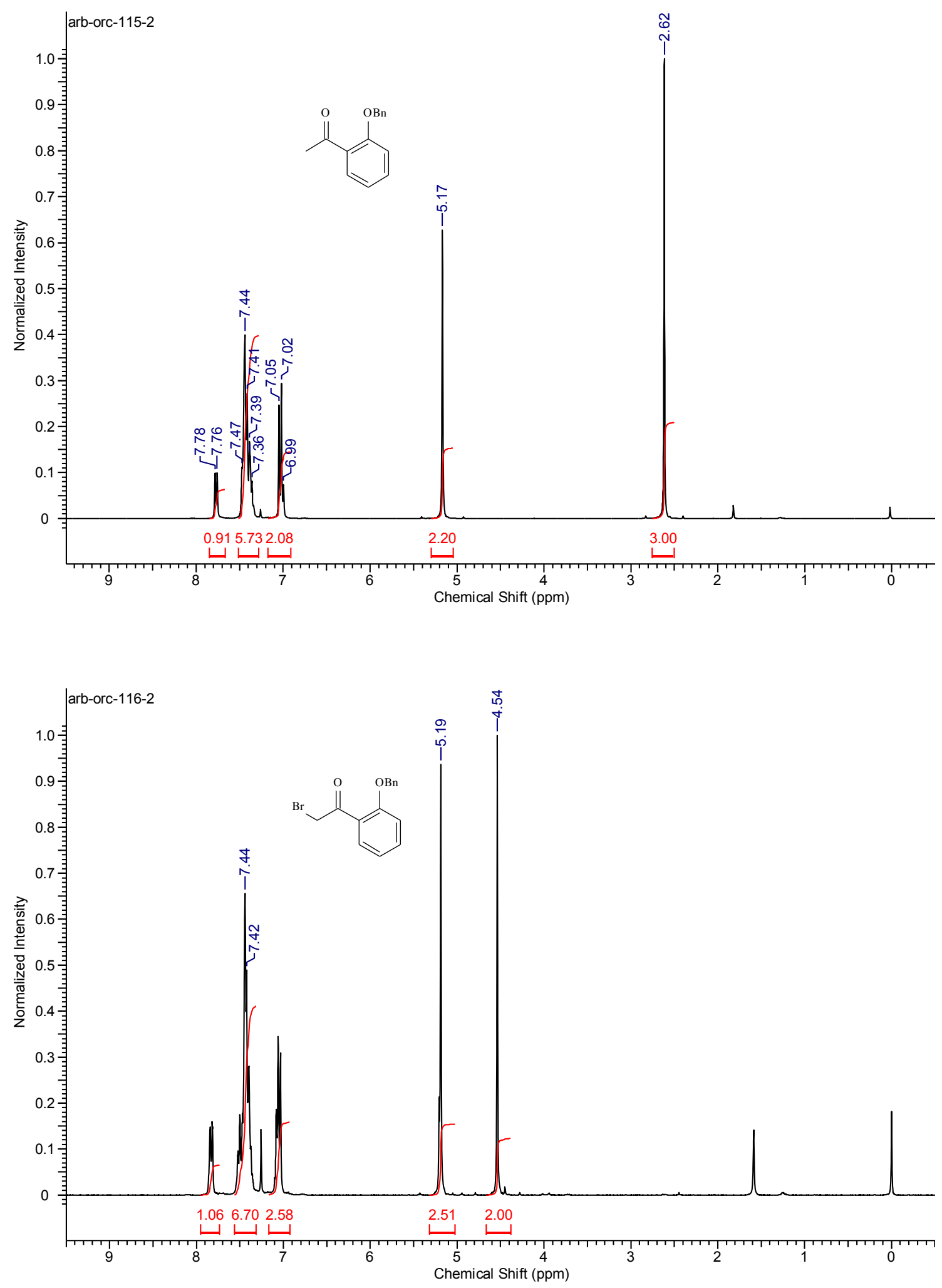

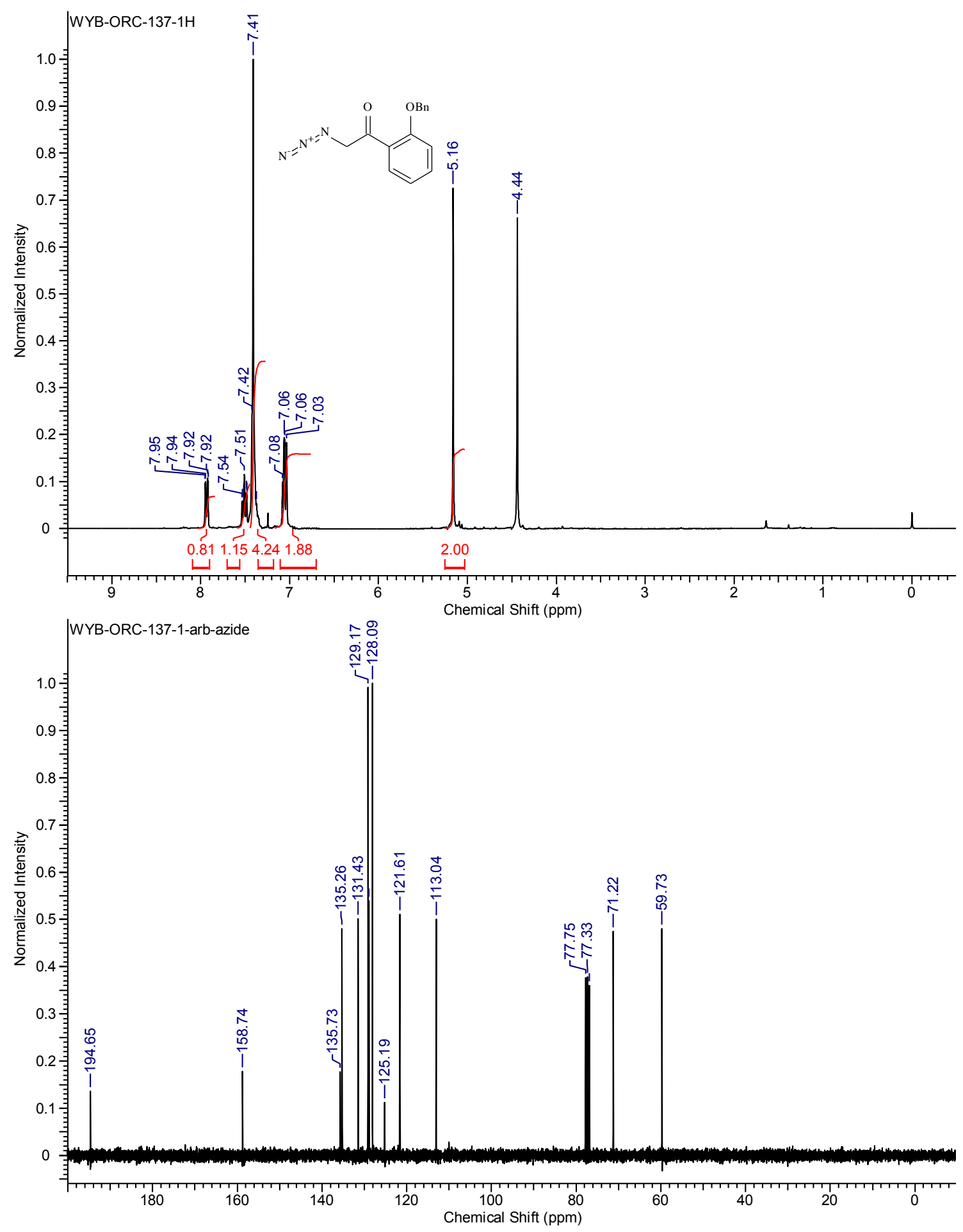

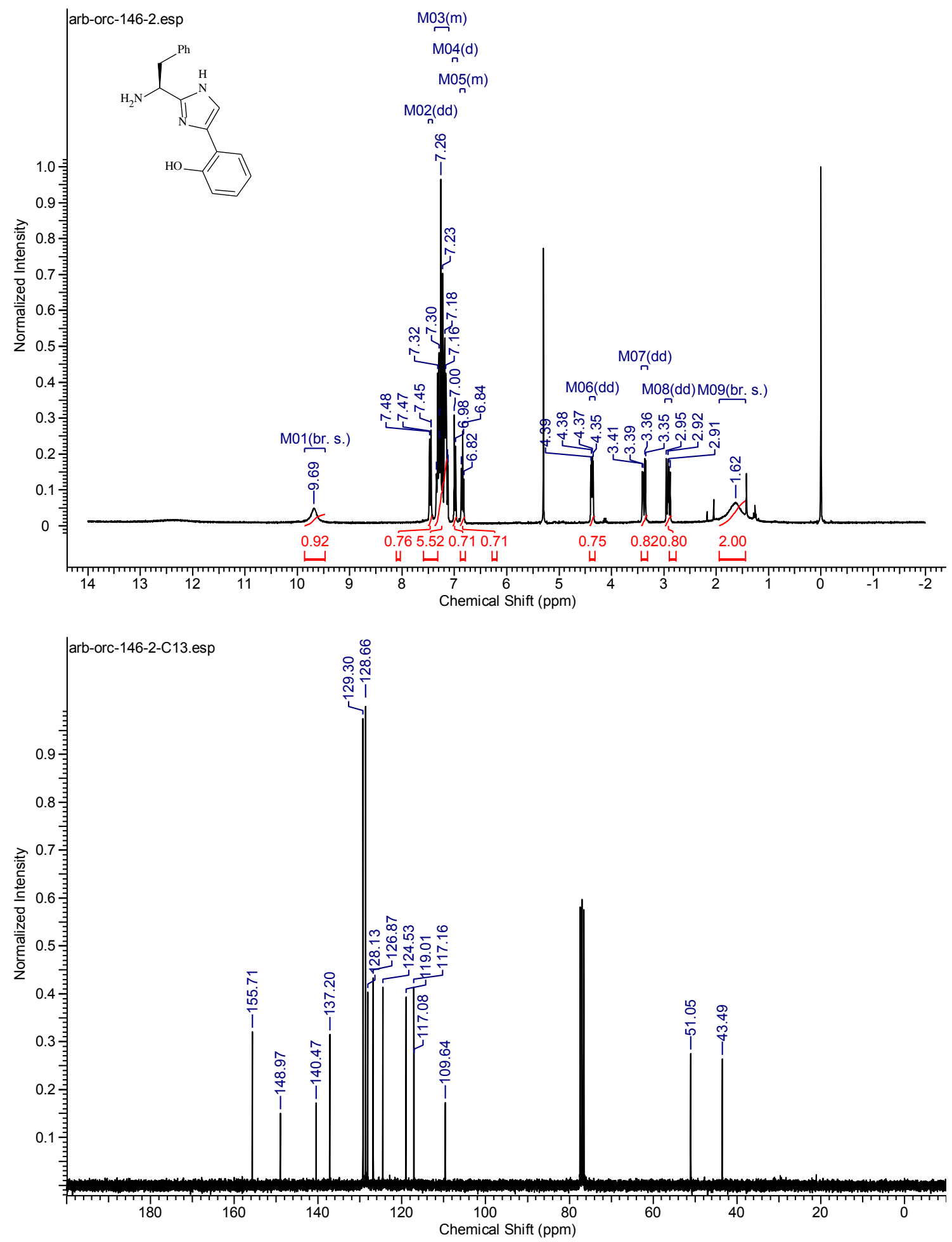

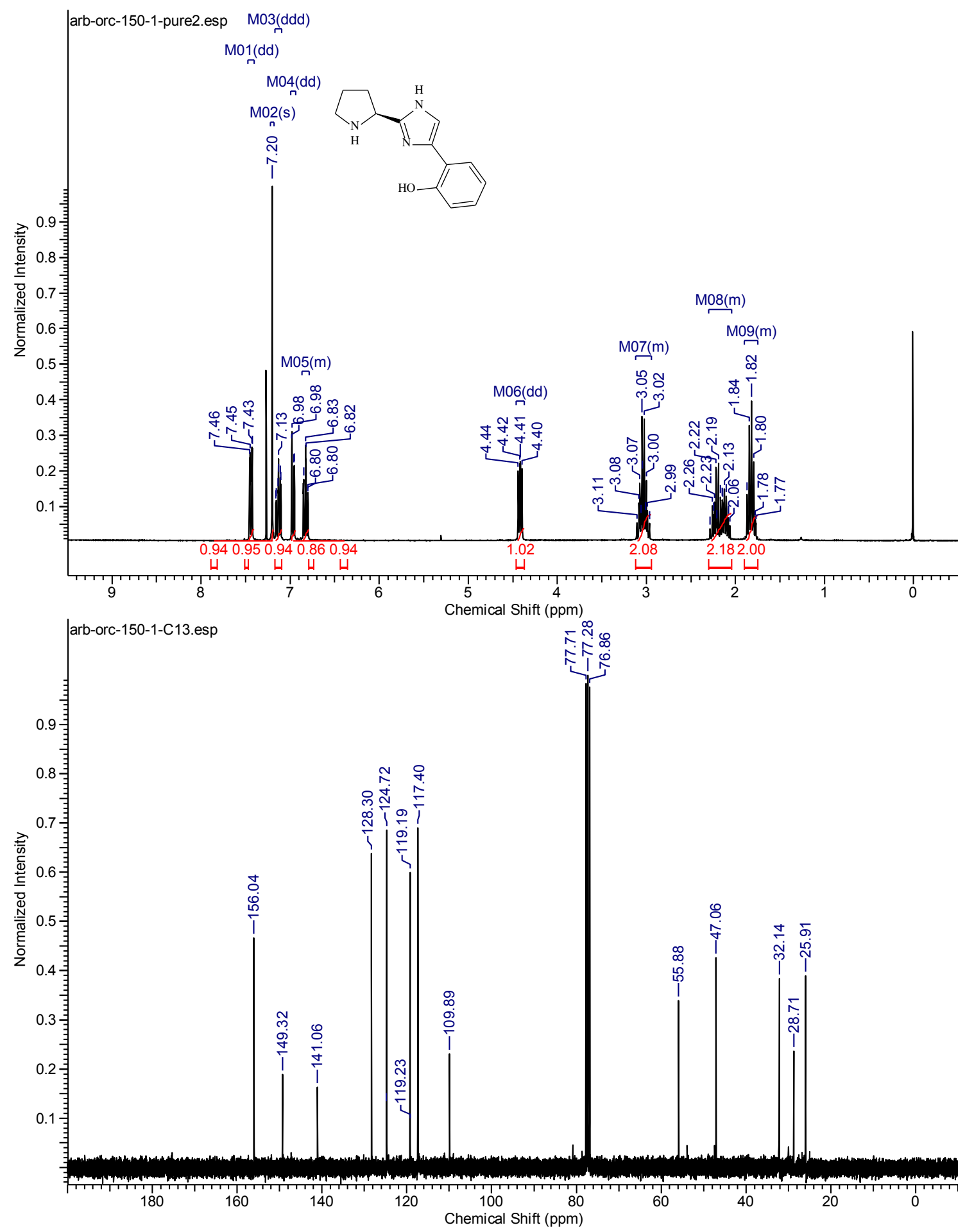

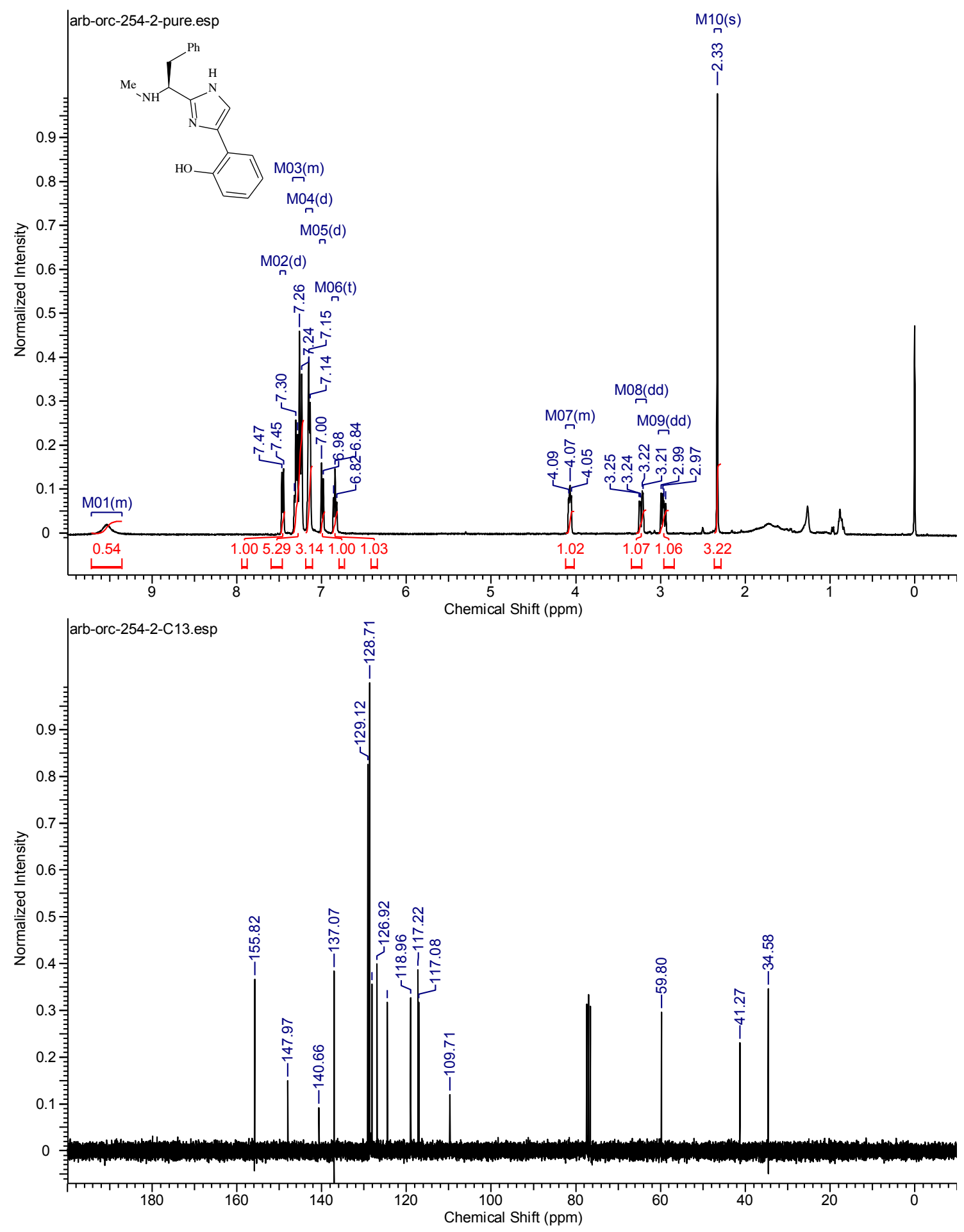